\title{
Role of Modelling in International Crop Research: Overview and Some Case Studies
}

\author{
Matthew Reynolds ${ }^{1}$, Martin Kropff ${ }^{1}$, Jose Crossa ${ }^{1}$, Jawoo Koo ${ }^{2}{ }^{\circledR}$, Gideon Kruseman ${ }^{1}{ }^{(D)}$ \\ Anabel Molero Milan ${ }^{1}{ }^{(D}$, Jessica Rutkoski ${ }^{3}$, Urs Schulthess ${ }^{4}$, Balwinder-Singh ${ }^{5}{ }^{\circledR}$, \\ Kai Sonder ${ }^{1, *}$, , Henri Tonnang ${ }^{6,7}$ and Vincent Vadez ${ }^{8,9}$ \\ 1 International Maize and Wheat Improvement Center (CIMMYT), El Batán, Texcoco CP 56130, Mexico; \\ m.reynolds@cgiar.org (M.R.); m.kropff@cgiar.org (M.K.); j.crossa@cgiar.org (J.C.); \\ g.kruseman@cgiar.org (G.K.); a.m.milan@cgiar.org (A.M.M.) \\ 2 International Food Policy Research Institute (IFPRI), 2033 K St, NW, Washington, DC 20006-1002, USA; \\ j.koo@cgiar.org \\ 3 International Rice Research Institute (IRRI), Los Baños, Laguna 4031, Philippines; j.rutkoski@irri.org \\ 4 CIMMYT, China Collaborative Innovation Center, Henan Agricultural University, Zhengzhou 450002, China; \\ u.schulthess@cgiar.org \\ 5 CIMMYT-India, NASC Complex, DPS Marg, New Delhi 110012, India; balwinder.singh@cgiar.org \\ 6 CIMMYT, ICRAF House, United Nation, Avenue, Gigiri, P. O. Box 1041-063 Village Market, Nairobi 00621, \\ Kenya; h.tonnang@cgiar.org \\ 7 International Institute of Tropical Agriculture (IITA), Abomey Calavi, 08 BP 0932 Tri Postal, Cotonou, Benin \\ 8 International Crop Research Institute for the Semi-Arid Tropics (ICRISAT), Patancheru, Hyderabad, \\ Telangana 502324, India; v.vadez@cgiar.org \\ 9 Institut de Recherche pour le Development (IRD), Université de Montpellier, UMR DIADE, 911 Avenue \\ Agropolis, BP 64501, 34394 Montpellier CEDEX 5, France \\ * Correspondence: k.sonder@cgiar.org; Tel.: +52-555-804-2004
}

Received: 5 November 2018; Accepted: 27 November 2018; Published: 4 December 2018

Abstract: Crop modelling has the potential to contribute to global food and nutrition security. This paper briefly examines the history of crop modelling by international crop research centres of the CGIAR (formerly Consultative Group on International Agricultural Research but now known simply as CGIAR), whose primary focus is on less developed countries. Basic principles of crop modelling building up to a Genotype $\times$ Environment $\times$ Management $\times$ Socioeconomic $(G \times E$ $\times \mathrm{M} \times \mathrm{S}$ ) paradigm, are explained. Modelling has contributed to better understanding of crop performance and yield gaps, better prediction of pest and insect outbreaks, and improving the efficiency of crop management including irrigation systems and optimization of planting dates. New developments include, for example, use of remote sensed data and mobile phone technology linked to crop management decision support models, data sharing in the new era of big data, and the use of genomic selection and crop simulation models linked to environmental data to help make crop breeding decisions. Socio-economic applications include foresight analysis of agricultural systems under global change scenarios, and the consequences of potential food system shocks are also described. These approaches are discussed in this paper which also calls for closer collaboration among disciplines in order to better serve the crop research and development communities by providing model based recommendations ranging from policy development at the level of governmental agencies to direct crop management support for resource poor farmers.

Keywords: crop modelling; international agricultural research; CGIAR; crop management; foresight; food security; agri-food-systems; global phenotyping networks; data sharing; big data 


\section{Introduction}

Current rates of yield growth and overall production are not sufficient to satisfy future demand [1] and climate change is predicted to add at least another 60 million hungry people by 2050 [2]. Rosegrant et al. [3] predicted that-in the absence of unprecedented, coordinated measures to raise productivity-consumers will pay double for staple foods by 2050 in real terms. While crop-focused research still achieves impressive productivity gains [4], multiple approaches must be employed to improve leverage of knowledge, expertise, and data to achieve greater returns on investment in agriculture and maintain global food security under the added challenges of climate change, resource scarcity, growing populations, and changing demand.

Crop modelling has the potential to significantly contribute to global food and nutrition security. New technologies and conceptual breakthroughs have contributed to a better understanding of crop performance and yield gaps, genetic gains, better prediction of pest and insect outbreaks, more efficient irrigation systems, and optimized planting dates. Newer developments include the use of remote-sensed data and mobile phone technology linked to simulation models [5]; improved geographic information system (GIS) techniques [6]; strategic crossing and selection models making use of high-throughput genotyping and phenotyping to increase genetic gains [7]; as well as data sharing and standardization in the new era of big data [8]. Renewed interest in crop modelling that addresses the challenges of climate change has already led to collaborative initiatives such as the Agricultural Model Intercomparison and Improvement Project (AgMIP) [9-11], the CGIAR Platform for Big Data in Agriculture (launched in 2017) [8], as well as other initiatives for dataset standardization [12]. Additional investments and large-scale collaborations are needed to improve the collection of open access, easy to use data for crop modelling purposes [13].

This paper briefly outlines the history of crop modelling, including major theoretical advances and their practical applications by international crop research centres of the CGIAR. It shows that theory and field-level implementation evolved in tandem, with models and their applications making mutual improvements and refinements over time. Several successful applications of models are presented, highlighting their contributions in food security at multiple levels. Basic principles of crop modelling, building up to a new Genotype $\times$ Environment $\times$ Management $\times$ Socioeconomic $(\mathrm{G} \times \mathrm{E} \times \mathrm{M} \times \mathrm{S})$ paradigm, are explained. The application of these principles to environmental modelling, as well as crop management and breeding, is explained using multiple examples from CGIAR Centre's work throughout developing regions. Socioeconomic applications include foresight analysis of agricultural systems under global change scenarios, and the consequences of potential food system shocks. Using crop modelling to achieve strong global development impacts depends on the contribution of a wide range of stakeholders-from academia to private companies-to large, multi-location datasets. The need for greater collaboration between modelling disciplines is a driver of this paper.

Crop modelling in the target environments of the CGIAR centres has its own unique challenges in addition to the fact that many of the regions face direct climate change and other resource limitations, e.g., related soil erosion and unavailability of good quality water. For example, crop models require comprehensive weather data for simulations to run and to explain $\mathrm{G} \times \mathrm{E}$ data, which is often not available or insufficient. Other aspects of environmental characterization of target environments may also be lacking, including data on soils types, fertility regimes and even water application. While the expansion of crop modelling approaches is still somewhat limited by the availability of quality data for calibration, validation, and evaluation, recent progress in the development of large-scale agro-ecological datasets, facilitated by global initiatives such as AgMIP [10] and the Big Data Platform in Agriculture [8], are helping fill the data gap.

Modelling innovations can address increasing concerns on sustainable food production, nutrition, and natural resource management challenges, and their consequences on closely associated socioeconomic issues such as conflict, migration, human health, and gender inequality. While this 
review takes stock of the state-of-the-art of crop related modelling within CGIAR, it also highlights where improvements are desirable and feasible.

\section{Basic Principles and History of Crop Modelling}

Agricultural systems modelling dates to the late 1950s, while specific crop models entered the scene a decade later [14]. Models have been used, for example, to identify best farm management practices, manage production risks, assess climate change impacts, and develop breeding strategies. Table 1 describes the major modelling achievements of the CGIAR Centres since the 1970s, and indicates key publications associated with each development.

Table 1. Modelling developments by CGIAR centres, 1970s to present.

\begin{tabular}{|c|c|}
\hline \multicolumn{2}{|l|}{ 1970s FIRST RICE MODELS DEVELOPED } \\
\hline \multicolumn{2}{|l|}{ 1980s RICE MODELS } \\
\hline $\begin{array}{l}\text { International Rice Research Institute (IRRI): Models } \\
\text { developed for rice crops }\end{array}$ & Whisler, 1983 [15] \\
\hline \multicolumn{2}{|l|}{ 1990s FURTHER WORK ON RICE, BEANS, MAIZE } \\
\hline $\begin{array}{l}\text { International Rice Research Institute (IRRI): ORYZA } \\
\text { model family developed: IRRI, Wageningen UR \& } \\
\text { National Agricultural Research Systems of } 9 \text { Asian } \\
\text { countries, Systems Analysis and Simulation in Rice } \\
\text { Production (SARP) project. Yield gap analysis, } \\
\text { identifying management constraints, climate change } \\
\text { analysis, declining yields, Modelling interplant } \\
\text { competition (INTERCOM models), Water management } \\
\text { optimization, Linking crop and pest models, Plant type } \\
\text { design and breeding strategies, Comparing yields in long } \\
\text { term trials across years to yield potential, Optimize grain } \\
\text { yields with minimum methane emissions, Predict impact } \\
\text { of climate change on rice production in Asia using all } \\
\text { SARP data }\end{array}$ & $\begin{array}{l}\text { Kropff et al., } 1993 \text { [16]; Kropff and Van Laar, } 1993 \text { [17]; } \\
\text { Kropff et al., 1994 [18]; Wopereis et al., 1994 [19]; Kropff } \\
\text { et al., } 1995 \text { [20]; Matthews et al., } 1995 \text { [21]; Aggarwal et al., } \\
1997 \text { [22]; Kropff et al., } 1997 \text { [23]; Teng et al., } 1997 \text { [24] }\end{array}$ \\
\hline $\begin{array}{l}\text { West Africa Rice Development Association (WARDA, } \\
\text { now known as Africa Rice Center): Rice modeling, } \\
\text { model improvement, impact of climate changes in rice } \\
\text { yields, genotype by environment }\end{array}$ & $\begin{array}{l}\text { Dingkuhn et al., } 1995 \text { [25]; Dingkuhn and Miezan, } 1995 \\
\text { [26]; Dingkuhn, } 1995 \text { [27]; Dingkuhn 1996 [28]; Dingkuhn } \\
\text { and Sow, } 1997 \text { [29]; Asch et al., } 1997 \text { [30]; Sié et al., } 1998 \\
\text { [31-33]; Dingkuhn and Asch, } 1999 \text { [34] }\end{array}$ \\
\hline $\begin{array}{l}\text { International Crops Research Institute for the } \\
\text { Semi-Arid Tropics (ICRISAT): Groundnut modelling }\end{array}$ & $\begin{array}{l}\text { Boote et al., } 1992 \text { [35]; Singh et al., } 1994 \text { [36]; Singh and } \\
\text { Virmani, } 1996 \text { [37] }\end{array}$ \\
\hline $\begin{array}{l}\text { International Centre for Tropical Agriculture (CIAT): } \\
\text { Bean model development }\end{array}$ & $\begin{array}{l}\text { Hoogenboom et al., } 1994 \text { [38]; Hoogenboom et al., } 1995 \\
\text { [39]; Acosta-Gallegos et al., } 1996 \text { [40] }\end{array}$ \\
\hline $\begin{array}{l}\text { International Maize and Wheat Improvement Centre } \\
\text { (CIMMYT): Maize modelling }\end{array}$ & Elings et al., 1997 [41] \\
\hline \multicolumn{2}{|c|}{ 2000s INNOVATIONS IN CROP MODELLING APPROACHES AT CGIAR CENTRES } \\
\hline $\begin{array}{l}\text { International Crops Research Institute for the } \\
\text { Semi-Arid Tropics (ICRISAT): Crop management, yield } \\
\text { gap analysis, analysis of soil constraints and abiotic stress } \\
\text { impact for soybean, groundnut and sorghum }\end{array}$ & $\begin{array}{l}\text { Alagarswamy et al., } 2000 \text { [42]; Naab et al., } 2004 \text { [43]; Bhatia } \\
\text { et al., } 2006 \text { [44]; Bhatia et al., 2008 [45]; Singh et al., } 2009 \text { [46] }\end{array}$ \\
\hline $\begin{array}{l}\text { International Potato Centre (CIP): Growth potential and } \\
\text { targeting varieties for potatoes and Andean tubers. } \\
\text { Disease modelling for potatoes }\end{array}$ & $\begin{array}{l}\text { Hijmans et al., } 2000 \text { [47]; Hijmans, } 2003 \text { [48]; Hijmans et al., } \\
2003 \text { [49]; Hijmans et al., } 2003 \text { [50]; Andrade-Piedra et al., } \\
2005 \text { [51]; Andrade-Piedra et al., } 2005 \text { [52]; Andrade-Piedra } \\
\text { et al., 2005 [53]; Condori et al., } 2008 \text { [54]; Forbes et al., } 2008 \\
\text { [55]; Condori et al., } 2010 \text { [56] }\end{array}$ \\
\hline $\begin{array}{l}\text { International Rice Research Institute (IRRI): Further } \\
\text { rice model development }\end{array}$ & $\begin{array}{l}\text { Bouman et al., } 2001 \text { [57]; Dernier van der Gon et al., } 2002 \\
\text { [58]; Kropff et al., } 2003 \text { [59] }\end{array}$ \\
\hline $\begin{array}{l}\text { Africa Rice Center (AfricaRice): Intercropping systems, } \\
\text { yield gap in rice }\end{array}$ & $\begin{array}{l}\text { Akanvou, } 2001 \text { [60]; Haefele et al., } 2003 \text { [61]; Akanvou } \\
\text { et al., } 2006 \text { [62]; van Asten et al., } 2003 \text { [63] }\end{array}$ \\
\hline $\begin{array}{l}\text { International Centre for Tropical Agriculture (CIAT): } \\
\text { Crop management strategies for dry bean and other } \\
\text { tropical legumes }\end{array}$ & $\begin{array}{l}\text { Hartkamp et al., } 2002 \text { [64]; Jones and Thornton, } 2003 \text { [65]; } \\
\text { Jarvis et al., } 2008 \text { [66] }\end{array}$ \\
\hline
\end{tabular}


Table 1. Cont.

\begin{tabular}{ll}
\hline $\begin{array}{l}\text { International Maize and Wheat Improvement Centre } \\
\text { (CIMMYT): Modelling for maize and wheat breeding, } \\
\text { crop-livestock interactions }\end{array}$ & $\begin{array}{l}\text { Hunt et al., 2003 [67]; Hodson and White, 2007 [68]; } \\
\text { Erenstein et al., 2007 [69] }\end{array}$ \\
\hline $\begin{array}{l}\text { International Livestock Research Institute (ILRI): } \\
\text { Crop-livestock interactions }\end{array}$ & Singh et al., 2007 [70]; Erenstein et al., 2007 [69] \\
\hline $\begin{array}{l}\text { International Food Policy Research Institute (IFPRI): } \\
\text { Impact of climate Change on Agriculture, soil monitoring }\end{array}$ & Koo et al., 2007 [71]; Nelson et al., 2009 [72] \\
\hline $\begin{array}{l}\text { 2010s New interest in global and regional modelling focused on climate change foresight work, strong linkages } \\
\text { with AgMIP, modelling groups at UF, CSIRO. Modelling work covering a wide range of uses including agronomy, } \\
\text { rotations, agroforestry }\end{array}$ &
\end{tabular}
aroforestry

CIAT: Climate change impact analysis, including future climates in analogous environments, uncertainties of models and comparisons, abiotic stress testing

IFPRI: Grid-based crop modelling to inform regional and global-scale simulation of food security and international trades under scenarios of agricultural technology developments, food policy, and climate changes

IRRI: Climate change foresight work, genomics studies incorporating crop modelling, abiotic stress modelling, model improvement, improved breeding speed with model assisted selection

CIMMYT: Climate change foresight work on maize and wheat, model improvement, conservation agriculture ex ante modelling, testing of management interventions, Genotype $\times$ Environment Interactions

ICRISAT: Testing genotypes for breeding program orientation, climate change foresight work, drought testing, phenotype evaluations for drought stress, fertilizer response testing, abiotic stress modelling, mixed crop-livestock systems
Jarvis et al., 2012 [73]; Ramirez-Villegas et al., 2013 [74];

Ramirez-Villegas et al., 2015 [75]; Cammarano et al., 2016

[76]; Eitzinger et al., 2017 [77] Durand et al., 2017 [78];

Ramirez-Villegas et al., 2017 [79]; Piikki et al., 2017 [80];

Fodor et al., 2017 [81]; Heinemann et al., 2017 [82];

Ramirez-Villegas et al., 2018 [83]; Cammarano et al., 2017

[84]; Challinor et al., 2018 [85]

Nelson et al., 2010 [86]; Wiebelt et al., 2013 [87]; Robertson

et al., 2013 [88]; Negassa et al., 2013 [89]; Nelson et al., 2014

[90]; Nelson et al., 2014 [91]; Rosegrant et al., 2014 [92];

Muller and Robertson, 2014 [93]; Wiebe et al., 2015 [2];

Robinson et al., 2015 [94]; Robinson et al., 2015 [95]; Islam

et al., 2016 [96]; Zougmoré et al., 2017 [97]; Rosegrant et al., 2017 [98]; Rosenzweig et al., 2018 [99]

Li et al., 2013 [100]; Li et al., 2015 [101]; Li et al., 2015 [102];

Silva et al., 2017 [103]; Dingkuhn et al., 2017a [104];

Dingkuhn et al., 2017b [105]; Mottaleb et al., 2017 [106]; Li et al., 2017 [107]; Savary et al., 2018 [108]

Ngwira et al., 2014 [109]; Chung et al., 2014 [110]; Gbegbelegbe et al., 2014 [111]; Tesfaye et al., 2015 [112];

Tesfaye et al., 2016 [113]; Corbeels et al., 2016 [114];

Rutkoski et al., 2016 [115]; Gaydon et al., 2017 [116];

Aldermann and Stanfill, 2017 [117]; Maiorano et al., 2017

[118]; Tesfaye et al., 2017 [119]; Tesfaye et al., 2017 [120];

Tonnang et al., 2017 [121]; Jain et al., 2017 [122]; Sukumaran et al., 2017 [123]; Sukumaran et al., 2017 [124]; Juliana et al., 2017 [125]; Juliana et al., 2017 [126]; Pérez-Rodríguez et al., 2017 [127]; Montesinos-López et al., 2017 [128];

Montesinos-López et al., 2017 [129]; Montesinos-López et al., 2017 [130]; Sun et al., 2017 [131]; Jarquín et al., 2017 [132]; Dunckel et al., 2017 [133]; Cuevas et al., 2017 [134]; Crossa et al., 2017 [135]; Crespo-Herrera et al., 2017 [136]; Corbeels et al. 2018 [137]; Tesfaye et al., 2018 [138]; Montesinos-López et al., 2018 [139]; Montesinos-López et al., 2018 [140]; Cuevas et al., 2018 [141]; Sukumaran et al., 2018 [142]

Vadez et al., 2012 [143]; Singh et al., 2012 [144]; Vadez et al., 2013 [145]; Vadez and Kholova, 2013 [146]; Craufurd et al., 2013 [147]; Nedumaran et al., 2013 [148]; Kholova et al., 2013 [149], Homann-Kee et al., 2013 [150]; Kholova et al., 2014 [151]; Sinclair et al., 2014 [152]; Singh et al., 2014 [153]; Singh et al., 2014 [154]; Singh et al., 2014 [155]; Singh et al., 2014 [156]; Soltani et al., 2016 [157]; Vadez et al., 2017 [158]; Traore et al., 2017 [159]; Singh et al., 2017 [160];

Mohammed et al., 2017a [161]; Mohammed et al., 2017b [162]; Boote et al., 2017 [163]; Nelson et al., 2018 [164]; Faye et al., 2018 [165]; Adam et al., 2018 [166] 
Table 1. Cont.

\begin{tabular}{|c|c|}
\hline $\begin{array}{l}\text { CIP: Potato disease modelling, foresight, further model } \\
\text { development }\end{array}$ & $\begin{array}{l}\text { Kroschel et al., } 2013 \text { [167]; Sporleder et al., } 2013 \text { [168]; } \\
\text { Condori et al., } 2014 \text { [169]; Carli et al., } 2014 \text { [170]; } \\
\text { Kleinwechter et al., 2016 [171]; Kroschel et al., } 2017 \text { [172]; } \\
\text { Fleisher et al., } 2017 \text { [173]; Raymundo et al., } 2017 \text { [174]; } \\
\text { Raymundo et al., } 2017 \text { [175]; Quiroz et al., } 2017 \text { [176]; } \\
\text { Ramirez et al., 2017 [177]; Mujica et al., } 2017 \text { [178]; Scott } \\
\text { and Kleinwechter, } 2017 \text { [179]; Petsakos et al., } 2018 \text { [180] }\end{array}$ \\
\hline $\begin{array}{l}\text { AfricaRice: Model improvement, yield gap analysis, } \\
\text { genotype } \times \text { environment interactions, impact of climate } \\
\text { change }\end{array}$ & $\begin{array}{l}\text { van Oort et al., } 2014 \text { [181]; van Oort et al., } 2015 \text { [182]; van } \\
\text { Oort et al., } 2015 \text { [183]; Dingkuhn et al., } 2015 \text { [184]; van Oort } \\
\text { et al., } 2016 \text { [185]; El-Namaky and van Oort, } 2017 \text { [186]; van } \\
\text { Oort et al., 2017 [187]; Dingkuhn et al., } 2017 \text { [104,105]; van } \\
\text { Oort and Zwart, 2018 [188]; van Oort, } 2018 \text { [189], Duku } \\
\text { et al., } 2018 \text { [190] }\end{array}$ \\
\hline ICRAF: Agroforestry and intercropping modelling Africa & $\begin{array}{l}\text { Luedeling et al., } 2014 \text { [191]; Araya et al., } 2015 \text { [192]; } \\
\text { Luedeling et al., } 2016 \text { [193]; Smethurst et al., } 2017 \text { [194], } \\
\text { Masikati et al., } 2017 \text { [195] }\end{array}$ \\
\hline ILRI: crop-livestock-farm interactions & Van Wijk et al., 2014 [196]; Herrero et al., 2014 [197] \\
\hline IITA: Modelling on Yams in West Africa & $\begin{array}{l}\text { Marcos et al., } 2011 \text { [198]; Cornet et al., } 2015 \text { [199]; Cornet } \\
\text { et al., } 2016 \text { [200] }\end{array}$ \\
\hline $\begin{array}{l}\text { ICARDA: Climate variability and change impact studies, } \\
\text { foresight, conservation agriculture impact, genotype } \times \\
\text { environment interactions }\end{array}$ & $\begin{array}{l}\text { Sommer et al., } 2013 \text { [201]; Bobojonov and Aw-Hassan, } 2014 \\
\text { [202]; Dixit and Telleria, } 2015 \text { [203]; Frija and Telleria, } 2016 \\
\text { [204]; Ghanem et al., 2015 [205]; Ghanem et al., 2015 [206]; } \\
\text { Soni et al., } 2016 \text { [207]; Mohammed et al. [161], 2017; Dixit } \\
\text { et al., 2018 [208]; Mohammadi et al., 2018 [209] }\end{array}$ \\
\hline
\end{tabular}

In their simplest form, crop models represent a quantitative axiom (e.g., growth = light interception $\times$ radiation use efficiency) backed by a large body of empirical data. Where data is lacking, however, a model may constitute a qualitative but testable hypothesis (i.e., a conceptual model, whether it be biophysical or socioeconomic). By combining such elements, more complex quantitative or semi-quantitative simulation models can be developed. However, all models-including crop growth models-inherently suffer from the fact that they are abstractions of reality. This review does not dwell on the well-documented shortcomings of crop growth modelling [210-213], but instead discusses their useful applications in improving farmers' livelihoods and increasing food security.

This review considers crop productivity models within the framework of the widely used conceptual model $\mathrm{G} \times \mathrm{E} \times \mathrm{M}(\mathrm{GEM})$, representing the three most important biophysical variables that directly determine crop growth, and their interactions. Namely, expression of the genetic potential of a cultivar $(\mathrm{G})$, the physical environment of the crop (E), and crop management inputs (M). However, these three elements are also influenced indirectly by socioeconomic factors (S), such as supply and demand of inputs/outputs, finance and credit, agricultural policies, and the adaptive practices of farmers and consumers, thus extending the paradigm to $\mathrm{G} \times \mathrm{E} \times \mathrm{M} \times \mathrm{S}$.

\subsection{Environment}

In crop productivity models, $\mathrm{E}$ must be defined in terms of the variables that most strongly affect growth. This presents some challenges: firstly, E has almost infinite dimensions. The crop inhabits the soil and the atmosphere, where it interacts with physical, chemical, and biotic factors. Light and temperature regimes are in constant flux and essential molecules exist in solid, liquid, and gas phases-often interchangeably. When defining E, macroscopic, microscopic, and biotic domains must also be considered. Which variables most strongly affect growth is still a subject for research. Secondly, data of many of these factors are not readily available-hardly surprising considering that crops are grown on over 1 billion ha of land worldwide. Thirdly, while some of these dimensions are predictable, the key drivers of productivity - temperature, radiation, and rainfall—are highly variable on most relevant time scales and subject to climate change. Long term detailed weather datasets are crucial, preferably at a high density. It is for these reasons that GIS (Geographic Information System) has 
emerged as one of the most important and necessary disciplines in crop research and modelling in recent decades [6].

\subsection{Management}

$\mathrm{M}$ is essentially a subset of $\mathrm{E}$. Yet it is given special status since, unlike $\mathrm{E}$, the factors associated with $\mathrm{M}$ are controlled. The most widely adopted crop models are those that demonstrate how yield gaps may be closed using $M$ interventions, namely fertilizer, irrigation, planting methods/dates, tillage, and other crop husbandry approaches [214]. The most advanced models evaluate a whole package of M interventions within a farmer-friendly decision support tool [215]. Taking a long-term view, such models can also be used to assess the broader environmental consequences of $\mathrm{M}$.

\subsection{Genotype}

$\mathrm{G}$ is the most challenging aspect of crop modelling, partly because of the complexity and diversity of biological organisms, and partly because-unlike livestock, for example-plants do not systematically control their temperature, making their interaction with $\mathrm{E}$ a constantly moving target. While models of $\mathrm{G}$ may be robust for 'model species' grown in controlled environments, and conceptual models of $\mathrm{G}$ may provide hypotheses about candidate traits for future target environments (e.g., [216]), the greatest challenge for crop modelling is to simulate $\mathrm{G} \times \mathrm{E}$ interaction to refine crop breeding strategies and deploy new cultivars. Crop models are typically driven by the effect of $\mathrm{E}$ on growth, especially water, nitrogen $(\mathrm{N})$, radiation and temperature. However, genotypic components are less accurately simulated, except for development rate, i.e., the duration to flowering and grain filling period (see $[217,218]$ and references therein).

\subsection{Socioeconomics}

While $S$ is potentially quantifiable and can inform the parameterization of crop models and their scenario developments, this is only possible when detailed household-level survey data is available. For example, World Bank's Living Standards Measurement Study—Integrated Surveys on Agriculture provides a nationally-representative, comprehensive snapshot of farmers' livelihoods and plot-level farm management practices, yet its coverage is currently limited to eight countries in sub-Saharan Africa. When available, this type of micro-level data provides context for on-farm productivity and the off-farm socioeconomic environments that impact farming households, such as their proximity to markets, access to extension and financial services, and capacity to manage production risks. This information can help define the crop management baseline, parameterize model input data, calibrate the model, evaluate model performance, and develop practical what-if scenarios that are affordable for farmers. Socioeconomic inputs (S) are discussed in Section 6, in the context of calculating food systems risks. At the more aggregate level, market interactions combined with policies, institutional arrangements, and governance define the socioeconomic circumstances in which crop management decisions (both choice of genotypes and management practices) are made at the farm level. The combination of the bio-physical environment and socioeconomic circumstances define the development domains where specific technologies can or cannot prevail [219-221].

\subsection{Interactions}

The full $\mathrm{G} \times \mathrm{E} \times \mathrm{M} \times \mathrm{S}$ paradigm can be overly complex, and most practical applications of crop modelling to date relate to $\mathrm{M}$ recommendations [215]. Thus, it is practical to consider two main classes of interaction: those where $\mathrm{G}$ is considered as a fixed/generic effect (i.e., $\mathrm{E} \times \mathrm{M}$ and $\mathrm{M} \times \mathrm{S}$ interactions), or where $G$ is a variable itself $(G \times E, G \times M$ and $G \times E \times M)$ (Figure 1, Sections 4-6). 


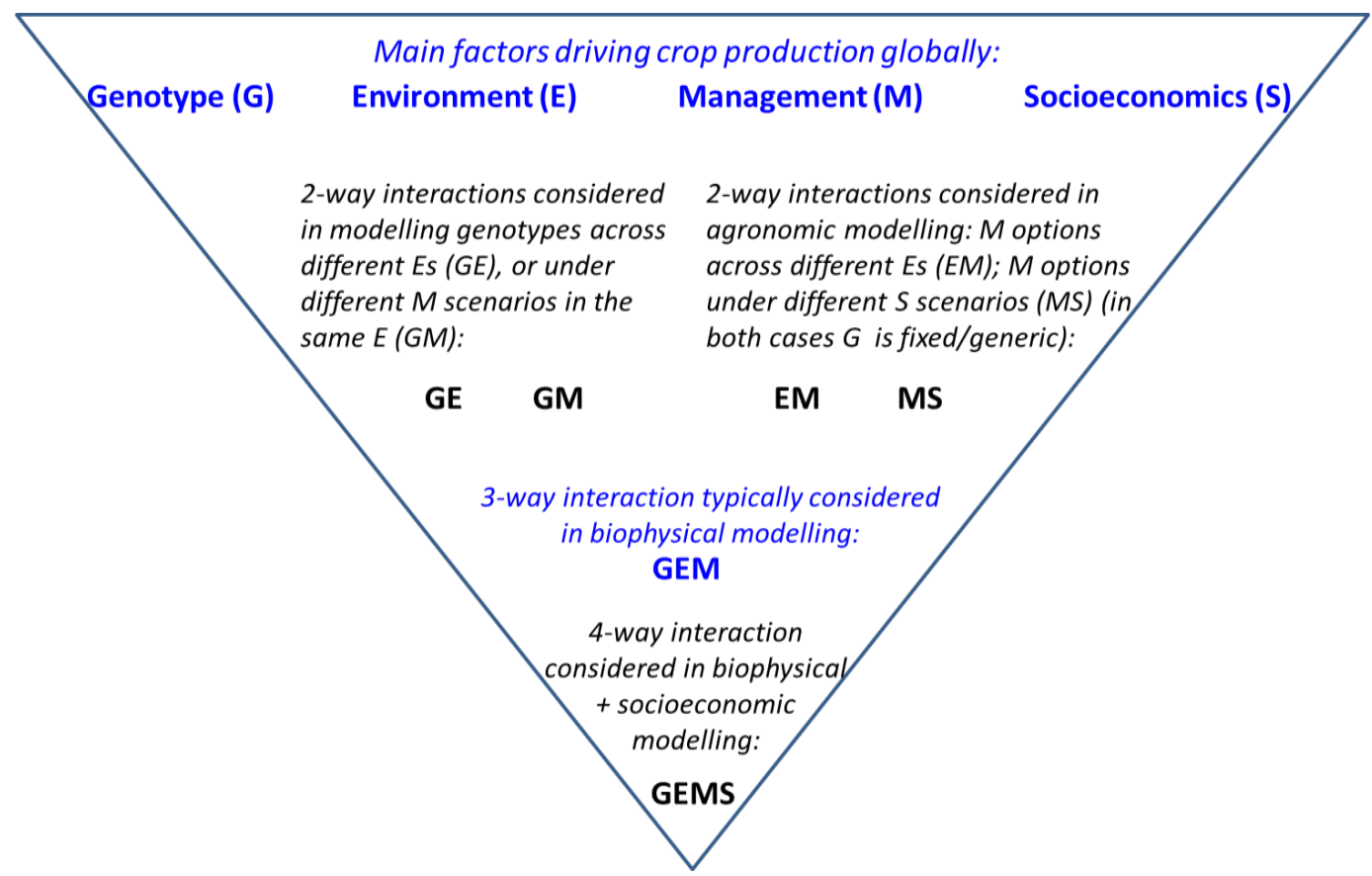

Figure 1. Crop modelling factors and relevant interactions. Four-way modelling captures the complex interactions of genotype, environment, management, and socioeconomics.

The modelling and research approaches outlined above are developed further in dedicated sections below. However, since models are only as good as their inputs, this review also addresses data standardization and sharing, as well as establishing and using phenotyping networks-activities that will hugely strengthen the scope and reliability of crop modelling.

\section{Modelling the Environment}

\subsection{The Physical Environment}

Environmental data are a crucial input for crop, environmental, and systems modelling. Their availability in terms of time lines, recording frequency, and location limits the ability and the representativeness of models. Ideally, sub-daily or daily data for at least a minimum set of environmental variables, particularly weather data (Table 2 ), are required $[23,24,222,223]$. Due to the increasingly global nature of cropping systems, the density of automatic weather stations is not sufficient, public access to data is limited, and/or the parameters needed for crop models are not sufficient (especially for larger areas in developing countries). In such cases, interpolated outputs from large climate datasets such as CRU (Climate Research Unit) or Worldclim are commonly used to provide monthly long-term average or long-term timeline environmental data for the models [224-227]. However, datasets like CRU have low resolution, which may cause problems with loss of spatial detail, especially in areas with high spatial heterogeneity [228].

Weather generators integrated into crop models or standalone models such as WGEN, SIMMETEO, or MARKSIM are commonly used to generate daily time series data [229-232]. The same applies to climate change applications to incorporate future climate scenarios into crop models, where all data utilized must be downscaled using dynamic or statistical approaches from larger global circulation model outputs and then run through a weather generator [230,233-237].

Soil data are equally important, and similar problems to those outlined above limit their use for larger areas. Specific sites (e.g., research stations) often have detailed soil profile data available, which can be used to create high quality soil input files, but the outputs of models for larger areas 
(country, regional, or global level) are limited in their reliability. Recent efforts have attempted to add detail to global soil databases and make them available for the modelling community [238-241].

Satellite-derived datasets, such as NASA's Tropical Rainfall Monitoring Mission (TRMM) and the Global Precipitation Mission (GPM), indicate that it might soon be possible to use a combination of remotely-sensed and ground-based data to collect precise, near real-time environmental data to run models at any given location-even in environments where data are scarce [242-245]. Remote sensing with a variety of sensors already allows monitoring and acquisition of surface soil moisture and solar radiation [246-248], as well as soil chemical and physical properties [249] (see Section 4.4).

Table 2. Generic standards for field phenotyping platforms to support simulation modelling (adapted from [250]).



Another aspect of modelling $\mathrm{E}$ includes that of predicting climate change, for which a vast body of literature exists. Given the timeframe for crop genetic improvement, the outputs of these models can be used by crop breeders and policymakers to plan long-term strategic investments. Pest and disease pressure is another key factor in modelling crop response to E, which is covered in Section 3.2.

\subsection{Tools for Monitoring and Managing Pests and Diseases}

Pests and diseases are an ever-present threat to crops worldwide, since they continually evolve to new pathotypes. As climate change and weather fluxes make it harder to predict their spread and virulence, multi-variable predictive models are becoming even more valuable as tools for crop protection. For pests, models can link organisms' physiological and phenological behaviour to environmental factors. For disease modelling, the life cycle is often represented by an infection chain, which corresponds to functional traits that can be converted to quantifiable processes and their responses linked to biological and environmental factors [252]. Within the CGIAR, these tools are being used to answer several relevant questions [121], such as: (1) how can we predict pest/disease vector population and disease transmission dynamics in the presence of multiple factors? (2) What impact do control agents have within an integrated pest management system? (3) How can we better 
understand and predict pest/disease propagation patterns over time and space? and (4) What are the priority locations/regions for conducting risk assessments and limiting potential invasions of pests/diseases [253]?

Modelling for pest and disease management generally utilizes an inductive or deductive approach. In the inductive ("top-down") approach, pest/disease occurrence is linked to the prevailing bio-climatic variable in a specific area, and then used to predict the likelihood of that organism occurring in another area [121]. Algorithms such as Maximum Entropy [254] and Genetic Algorithm for Rule Set Production [255] utilize the inductive approach. The deductive ("bottom-up") approach starts by modelling a species' response to climate variables and applies the model to predict the climate suitability of the organism. Inductive and deductive approaches can be combined using Climate and Population Modelling [256], which compares location function, and the NCSU (North Carolina State University) / APHIS (Animal and Plant Health Inspection Service) Plant Pest-Forecasting system (NAPPFAST) [257].

Case Study: Insect Life Cycle Modelling Software for Pest and Disease Management

One example of a deductive approach is applied in the Insect Life Cycle Modelling (ILCYM) open-source software package, developed by the International Potato Centre (CIP) $[168,258]$. It represents a breakthrough in conceptualization, development, and implementation of a tool for pest and disease management within the CGIAR. It uses non-linear functions $[259,260]$ and includes stochastic functions for variability in individual development times within a population [260]. ILCYM supports the analysis of life table data of insect species obtained from laboratory studies at constant temperatures and estimates, step-by-step, a mathematical expression to represent the species' development time, development rate, mortality, senescence, survival, and reproduction [121]. Functions derived for each stage are combined to give a process-oriented, temperature-driven, and age-stage structured insect phenology/population model. Linkages between the phenology model and the landscape are based on geo-reference daily/monthly minimum and maximum temperature values using a cosine or sinus function to mimic patterns under natural conditions. Further, three risk indices (establishment, generation, and activity) are derived to assess the potential distribution and abundance of the pest in a given location $[121,167,261]$.

Most of the tools developed to enhance management of pests/diseases require an estimate of model parameters [121]. Efforts have been made to address this, but challenges can remain when selecting a mathematical equation for a modelling approach. Paradoxically, obtaining good fit does not automatically indicate that the selected mathematical equation or method accurately describes the dynamics and interactions between the crop and the pest/disease [121,262,263]. Different model formulations may give excellent and equal fit to observed data, while their arithmetical characteristics produce dissimilar performance under field conditions [121].

Despite advances in modelling, the development and use of pest and disease models in isolation, as presented here, is not holistic and powerful enough. A reductionist approach, concentrating on a component rather than on the whole crop system [252] is not sufficient because, in reality, complex interactions exist between agricultural ecosystem components. Comprehensive modelling of crop development and yields requires multitrophic interactions, pest and disease impacts, ecosystem functions and processes to be combined, socio-ecological and socio-economic challenges, as well as respective feedback loops, biophysical flows, time delays, and nonlinearity within functional fluctuating bounds (Figure 2) [121]. Overall, as a remedy to current approaches and methods, we propose to put the study of the whole crop system before that of the components to achieve sustainable management in crop production $[121,252]$. 


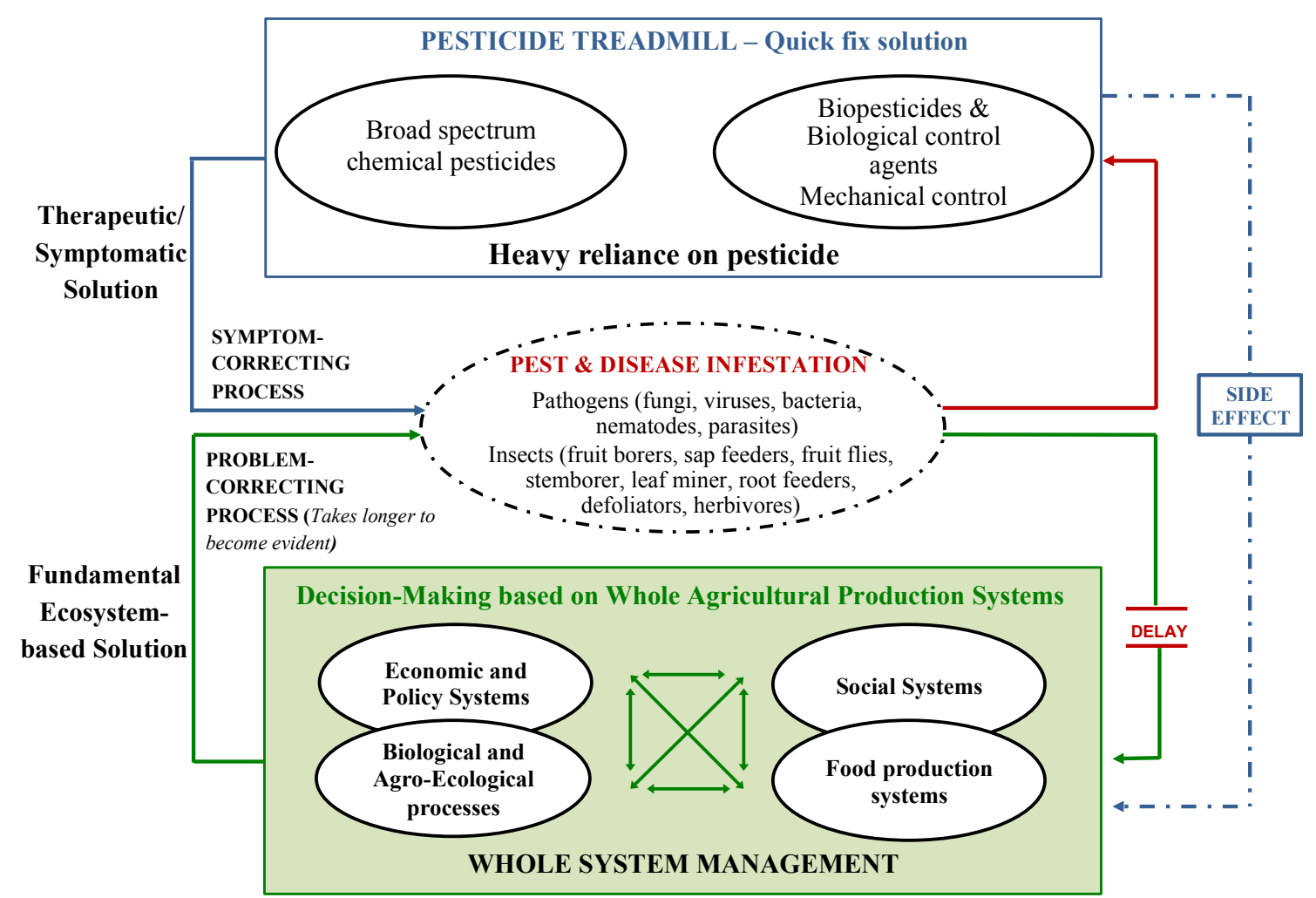

Figure 2. The figure displays a system thinking approach in which the study of the whole crop system is placed before that of the components such as pest or disease. The approach links all system components to provide a comprehensive assessment of crop production within the ecosystem with emphasis on multitrophic interactions including delays and side effect taking into account socio-economical and socio-ecological challenges. Figure was adapted with permission from H. Tonnang [121].

\section{Modelling Crop Management}

\subsection{Crop Models for Management Practices}

Crop simulation models have been successfully deployed in developed countries to manage farm resources including crop choice, crop variety, sowing date, plant density, irrigation, and inputs of nitrogen and phosphorus, but the quality of input data remains a challenge. Further, current problems related to sustainable intensification of agricultural systems cannot be solved by only optimizing these management practices, and many biophysical models lack components that computer metrics need to assess sustainable intensification related to soil health, for example [212]. Most current crop/cropping system models lack the capability to simulate more sophisticated management aspects that may co-limit crop productivity. These include management options such as the use of disease-resistant varieties, modified tillage, soil additives, micronutrients, changing row geometries, and more precise timing and placement of fertilizers, drip irrigation, use of surface mulches for modification of crop micro-environments, and erosion. Some of these limitations have been addressed in specific model modifications, but are not generally included in the widely distributed versions of the models. Some of these model applications are discussed in detail in [116], and efforts to address these limitations are ongoing [252].

Case Study: Exploring Sustainable Crop Management Options to Reduce Groundwater Table Decline in Northwest India

Irrigated rice (Oryza sativa L.)-wheat (Triticum aestivum L.) in northwest India is entirely dependent upon groundwater pumped from the underlying aquifer, resulting in alarming rates of reductions of the groundwater table and the potential for saline groundwater intrusion into fresh 
groundwater [264]. There is therefore great interest in finding sustainable solutions to arrest the decline in groundwater depth.

The Agricultural Production Systems sIMulator (APSIM) crop model (defined in Section 4.2) was applied to evaluate the effects of different crop management practices (rice variety duration, sowing date, replacing rice with other crops, and the use of conservation agriculture) on the land and water productivity of the total system, and on the components of water balance (Table 3) $[265,266]$.

The simulations gave the following results:

- If minimizing permanent loss of water from the system is the objective, the best method is a partial conservation agriculture rice-wheat system with a short duration rice variety.

- If maximizing productivity is the sole objective, a full conservation agriculture system with a medium duration variety is the best option.

- If the objective is to produce the maximum output per unit of evapotranspiration, this can be achieved using a short duration variety planted in mid-July under full conservation agriculture [265,266].

- Replacing rice with rainy season maize (Zea mays L.) in the system can maintain yields while reducing the total irrigation amount by $\sim 80 \%$, which can contribute to huge reductions in pumping costs and energy use. Maize-based systems also reduce permanent water loss from the system by $200 \mathrm{~mm}$ (Figure 3).

This approach can be extended to rainfed rice systems worldwide as a risk reducing strategy in a variable monsoon.

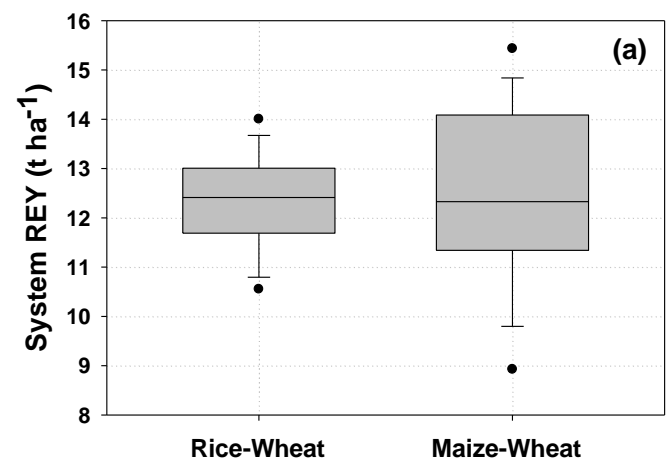

(a)

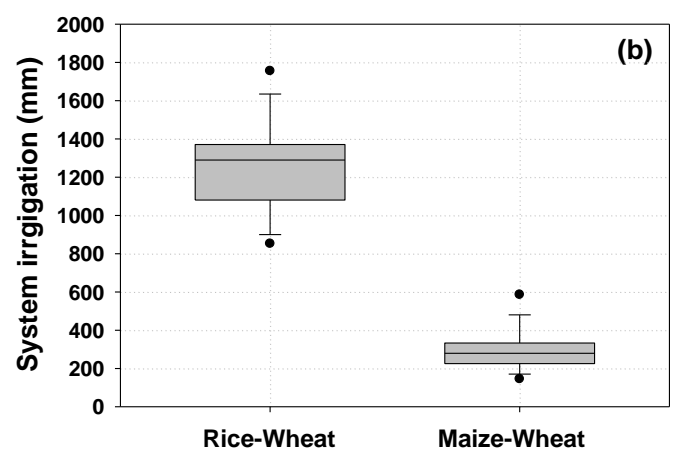

(b)

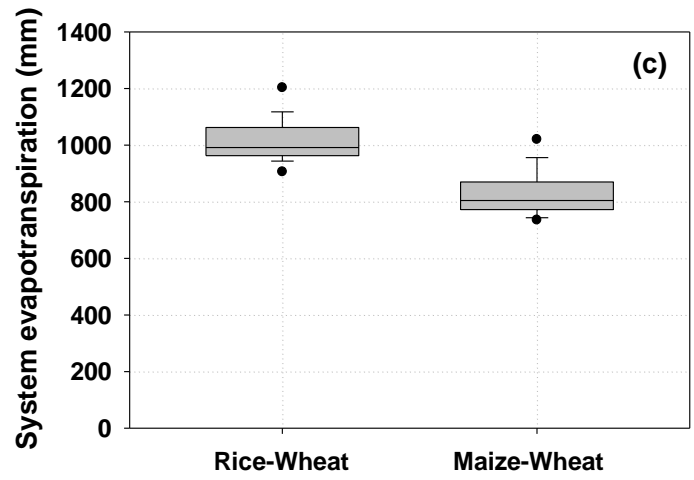

(c)

Figure 3. Probabilistic distribution of: (a) rice equivalent yield (REY), (b) irrigation, and (c) evapotranspiration of a rice-wheat system and maize-wheat system in central Punjab, India over 40 years (1970-2010). An example of how model outcome can be used to guide the field experimentation, given that testing all options in field is not feasible and are too expensive. Shaded bars are 25th-75th percentiles; whisker caps are 10th and 90th percentile and black dots 5th and 95th percentile, horizontal line is median. 
Table 3. Trade-off analysis between different system components under different objectives for various crop establishment methods, rice sowing dates, and variety duration [265,266]. FP-Farmer's practice, CA-Conservation Agriculture, REY—Rice equivalent yield, ET—Evapotranspiration, WP evapotranspiration, $\mathrm{WP}_{\mathrm{I}}$-Water productivity based on irrigation.

\begin{tabular}{|c|c|c|c|c|c|c|c|c|c|}
\hline Trade-Offs & $\begin{array}{c}\text { Crop Establishment } \\
\text { System }\end{array}$ & $\begin{array}{l}\text { Rice Variety } \\
\text { Duration }\end{array}$ & Rice Sowing & $\begin{array}{l}\text { System REY } \\
\left(\text { t ha }^{-1}\right)\end{array}$ & $\begin{array}{l}\text { Irrigation } \\
\quad(\mathrm{mm})\end{array}$ & $\begin{array}{c}\text { ET } \\
(\mathrm{mm})\end{array}$ & $\begin{array}{l}\text { Deep Drainage } \\
(\mathrm{mm})\end{array}$ & $\begin{array}{c}\mathrm{WP}_{\mathrm{I}} \\
\left(\mathrm{kg} \mathrm{ha}^{-1} \mathbf{m m}^{-1}\right)\end{array}$ & $\begin{array}{c}\mathrm{WP}_{\mathrm{ET}} \\
\left(\mathrm{kg} \mathrm{ha}^{-1} \mathrm{~mm}^{-1}\right)\end{array}$ \\
\hline Best FP & FP & Long (150 days) & Early June & 13.5 & 1380 & 1270 & 620 & 9.9 & 10.6 \\
\hline Highest productivity & Full CA & Medium (135 days) & Mid-June & 18.0 & 980 & 1360 & 300 & 19.1 & 13.3 \\
\hline Minimum irrigation & Full CA & Short (125 days) & Mid-June & 16.7 & 730 & 1180 & 370 & 23.9 & 14.2 \\
\hline Ground water depletion & Partial CA & Short (125 days) & June and July & 12.0 & 580 & 950 & 380 & 21.7 & 12.5 \\
\hline Society benefit & Full CA & Short (125 days) & Mid-July & 17.2 & 790 & 1160 & 315 & 22.8 & 14.8 \\
\hline
\end{tabular}




\section{2. $E \times M$ Interactions}

Crop simulation models can effectively account for the yield and growth effects of the interaction of environment with crop management $(\mathrm{E} \times \mathrm{M})$, assuming fixed $\mathrm{G}$ effects. One example is the AgroClimate program run by the University of Florida [267], which provides farmers with strategic advice regarding which crop to plant as a function of the El Niño-Southern Oscillation patterns. Another example is Yield Prophet ${ }^{\circledR}$, a web-based service that provides field-specific yield forecasts to optimize the investments of approximately 900 farmers, based on the Agricultural Production Systems sIMulator (APSIM) model, one of the major used crop models in agricultural systems [268]. APSIM was originally developed to model biophysical processes of crop production in farming systems with the purpose of evaluating options of management under climate risk conditions, it has been broadly used in research and more applied questions, decision making on farm level, crop supply chain planning, evaluation of policy options and others. The recent introduction of Smartphone applications aims to reach even more farmers than conventional tools, such as the Yield Prophet Lite application [269] and PANI (Program for Advanced Numerical Irrigation) [270]. However, the use of smartphone applications presents some challenges for some small farmers, such as the lack or unreliable internet connection, difficulties to recharge the mobile devices, illiteracy or poor education, high costs, among others. The RiceAdvice application, developed by Dr. Saito from AfricaRice for target yield, nutrient management, crop calendar and good agricultural practices, has partially solved some of these issues. The application runs offline, an important fact given poor connectivity and high internet prices in some areas in Africa, and an extensive training for service providers and users has been provided, thus overcoming some issues of illiteracy.

\section{Case Study: Irrigation Scheduling in Bangladesh's Ganges Delta Region}

In Bangladesh's southern delta, farmers mostly grow grass pea (Lathyrus sativus L.) and mungbean (Vigna radiata L.) during the Rabi (dry) season (December-April) [271]. These crops are generally not irrigated, instead drawing on residual soil moisture and the fact that the water table is close to the surface, fluctuating between 1-2.5 m depth in the dry season [272]. In this environment, tactical irrigation is a useful and cheap option to increase water use efficiency, especially as these crops can be a major source of cash income for smallholder farmers, while significant yield losses are often caused by sub-optimal plant establishment due to dry conditions around sowing.

The International Maize and Wheat Improvement Center (CIMMYT) conducted several experiments on maize, mungbean, and wheat in the delta region to better understand irrigation needs and develop a decision support app for farmers and irrigation service providers. Figure 4 shows the simulated soil water content, with and without capillary upflow (a function of soil type, rooting depth, and distance to the water table), based on work by Talsma [273] and an algorithm developed by W. Meyer for the farm-level water balance model BASINMAN [274]. The soil-water balance used in the smart phone application is based on the widely used CERES model, of which several specific crop variants are included in DSSAT (Decision Support System for Agrotechnology Transfer) [275], and can therefore be used under most conditions. Crop water use was estimated using percent ground cover, which can be estimated from optical remote sensing data [276,277]. In Bangladesh, field sizes tend to be too small to make use of the free Sentinel-2 satellite data, given its limited resolution. An application is being developed that estimates percent ground cover from RGB photos taken with a smartphone. 


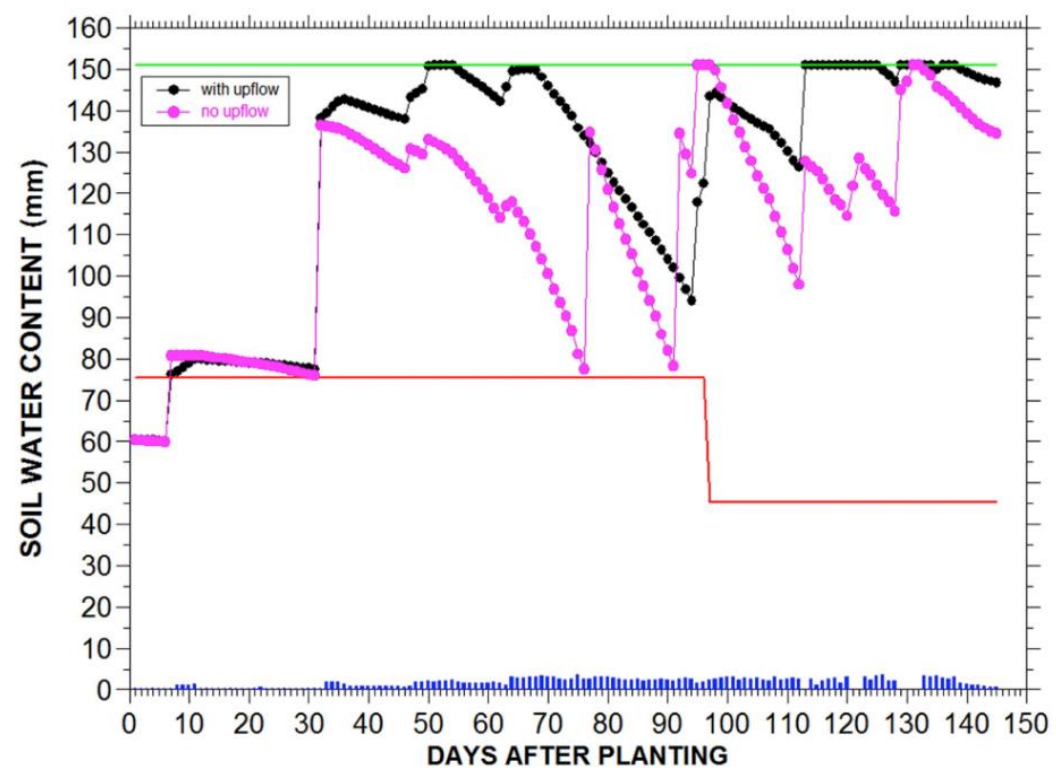

Figure 4. Simulated soil water content with and without capillary upflow. Bars at the bottom indicate daily upflow from the water table. The green line represents the drained upper limit, while the red indicates the target stress level (50\% of drained upper limit until anthesis and $30 \%$ thereafter). With a water table present, irrigations were required 7 and 32 days after planting, whereas without a water table, two more irrigations were required at 77 and 92 days after planting.

The simulation model has been integrated into a smartphone application called PANI (Program for Advanced Numerical Irrigation), which runs on a daily time step and uses forecasted daily maximum and minimum temperatures to predict irrigation needs one week in advance. PANI addresses the needs of irrigation service provider and farmers, as both receive a weekly SMS informing them whether a field needs to be irrigated or not. PANI demonstrates that it is possible to bring crop simulation models, or components thereof, to the fingertips of smallholder farmers. It is possible to automatically run the model with representative soil and weather information based on the GPS location; the only inputs required from the user are sowing and irrigation dates and ground cover photos taken every 10-15 days.

Bio-physical models can provide $\mathrm{M}$ options at both macro- and micro-environmental levels [215].

\section{3. $M \times S$ Interactions}

Yield gap is defined as the difference between potential yield and the actual yield obtained in farmers' fields [278]. Potential yield assumes that neither water, nutrients, nor biotic stress are limiting. Water-limited potential yield (instead of potential yield) is commonly used as a reference under rainfed conditions, and a further distinction is made for the yield potential of partially irrigated crops. Potential yield, water-limited potential yield, and partially irrigated potential yield can all be simulated in crop simulation models using optimal agronomic management (i.e., phenotype, sowing data, and planting density) as inputs [278]. Neither nutrient nor abiotic stresses are considered.

Many models, such as the Global Yield Gap Atlas, base optimum sowing dates, plant density, and cultivar on the dominant practices used by farmers. Crop simulation models have the advantage of being able to assess the year-to-year variability of potential yield (e.g., [18,59]). Often, actual yield data are obtained for just one or a limited number of years, thus crop simulation models can be used to assess whether the year for which the yield gap was analysed was representative or not [279]. More sophisticated analyses of e.g., nutrient- or pest-limited yield gaps, require specific inputs for the models, which often are not available in sufficient detail. 
Yield gap models enable production constraints on farmers' fields to be identified [279]. Region- or field-specific optimized crop management recommendations can then be generated using the example of farmers whose fields achieve the highest economic return.

Yield gap analysis has traditionally focused on agronomic crop production capacity and actual yields, but socioeconomic factors also play an important role. While the representation of yield gaps in Figure 5 ultimately involves $\mathrm{G} \times \mathrm{E} \times \mathrm{M} \times \mathrm{S}$ interactions, it highlights the interface between the biophysical and human or socioeconomic aspects of productivity. For any given E, $\mathrm{M}$ interventions are determined largely by $\mathrm{S}$, since they must be both feasible and cost-effective for the farmer. Potential yield and water-limited yield represent $G \times E$ potential, depending on the water regime. Nutrient-limited yield and part of the environment-reduced yields (due to biotic and abiotic pressures) can often be overcome by $\mathrm{M}$ (through proper fertilization, integrated pest management, etc.), assuming such interventions are economically feasible and socially acceptable.

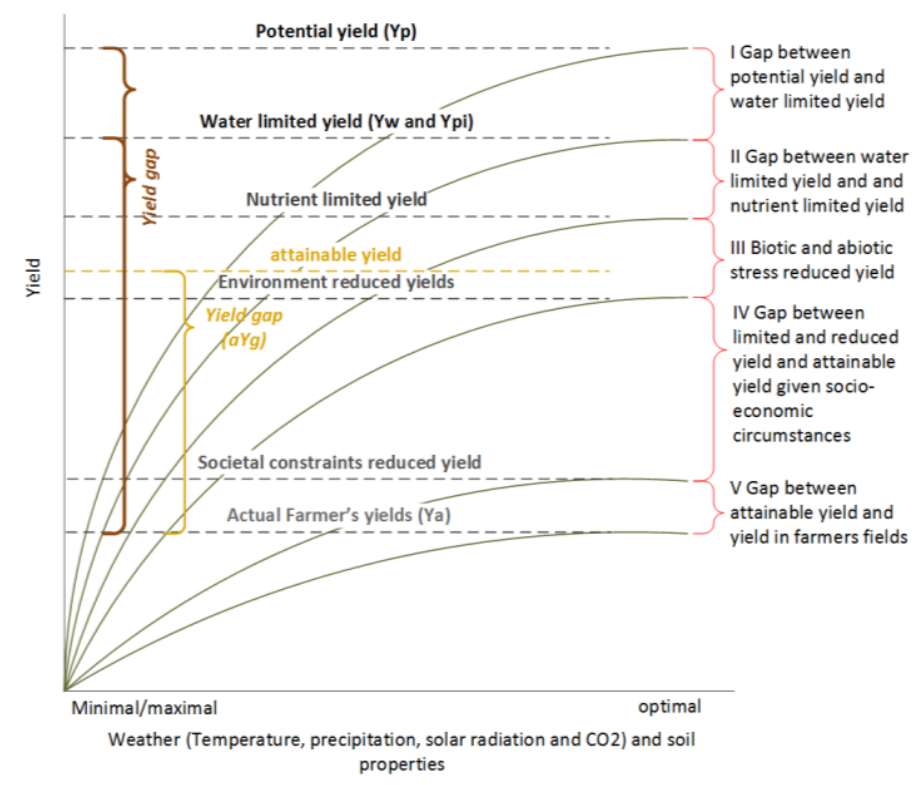

Figure 5. Graphical presentation of the various factors contributing to the yield gap. Actual yield is often limited by many interacting factors. Attempts have been made to incorporate this by introducing the concept of attainable yield, and the attainable yield gap. This is defined in terms of the best local [280] or global [281] practices, under similar biophysical and climatological circumstances.

Attainable yield levels are estimated using bio-economic models that incorporate household and community characteristics, and calibrated household-level objective functions, including risk management and imperfect information. In practice, farmers' actual yields may diverge from predicted yields due to idiosyncratic circumstances not accounted for in the model, such as the occurrence of household-level catastrophes. Models can be calibrated to take farm-specific circumstances into account and-if the level of yield reporting is sufficient and readily quantifiable $\mathrm{G} \times \mathrm{E} \times \mathrm{M} \times \mathrm{S}$ interactions are included - the difference between actual farmers' yields and modelled yields will be small. Bio-economic modelling can provide a set of M options relevant under different S scenarios [196,282]. Bio-economic modelling covers the ex-ante impact assessment of new technologies (including new varieties), combining socio-economic insights with explicit biological and biophysical process models. Extensive reviews of bio-economic models have been published (see [196,283-290]) and more detailed information about these models is described in Section 6.1. Bio-economic modelling at the farm level can take one of several approaches, some of which make assumptions about farmer behaviour and use these assumptions to analyse trade-offs (e.g., [5,291-297]).

Recent research by van Dijk et al. [298] uses econometric analyses at the household level to demonstrate how some of these issues might be resolved by integrating $\mathrm{M}$ and $\mathrm{S}$ approaches to yield 
gap measurement. The authors deconstruct the conventional yield gap indicator into four components to provide a better understanding of why actual farm yields fall below their potential: (1) the technical efficiency yield gap; (2) the economic yield gap; (3) the feasible yield gap; and (4) the technology yield gap $([299,300])$. These components are an alternative way of identifying the various components contributing to the yield gap as highlighted in Figure 5.

Building on these insights, and using ex-ante bio-economic modelling approaches, $\mathrm{M} \times \mathrm{S}$ interaction models can explore the cost-benefit of new technologies under different socioeconomic and climate scenarios, if interoperable agronomic, genetic, and socioeconomic datasets are available. Further issues related to the data availability are discussed in Section 6. The approach also requires more widely accessible bio-economic models at various levels of aggregation, which combine the biophysical process models with behaviour-based economic models, preferably as open-source models that allow communities of practice to be established [5].

\subsection{Technological Innovations Aiding Crop Management Models}

Remote sensing has the potential to characterize growth at high-throughput over space and time, and is thus a valuable tool for extending the inputs and calibration of crop simulation models. Optical data provide good estimates of crop light interception $[276,277]$ and have been successfully used to drive crop simulation models for yield and biomass predictions. Remote sensing can also estimate stress parameters; the widely used Normalized Difference Vegetation Index (NDVI) can indicate the cumulative effects of stress throughout the crop growth cycle (especially when referenced against non-stressed control plots). Other indices, such as the photochemical reflectance index [301] or chlorophyll fluorescence indices [302], can estimate the instantaneous effect of stress on radiation use efficiency. Satellite data can also detect key phenological stages, such as crop emergence, end of leaf growth in cereals, and maturity. This information reduces the burden of having to gather accurate crop management information from farmers, which is otherwise a major bottleneck for the widespread use of models.

Case Study: Anomalies in Irrigation Experiments in Maize Farmer's Fields Detected with Remote Sensors

As an example, remote sensing helped better understand perceived anomalies in an irrigation experiment conducted in maize farmers' fields in Bangladesh as part of a project developing PANI (see Section 4.2). In-season measurements of canopy temperature and ground cover showed that there were larger differences in crop growth within irrigation treatments than among them (Figure 6). This is because farmers intentionally create a relatively water-impermeable soil layer (a "hard pan") at a depth of 20-30 cm when cultivating fields for summer-season rice planting which affect root penetration and therefore the expression of canopy temperature. The land preparation for the maize irrigation experiment consisted of one pass with a power tiller and subsequent shaping of the beds. This was evidently not sufficient to brake the hard-pans in some of the previous rice paddy fields, as can be seen for the central plot of the irrigation experiment in Figure 6. The upper part suffered from dry conditions, which resulted in lower ground cover and higher canopy temperature as compared to the lower part of the plot. Soil measurements indicated the presence of hard pans related to the previous cropping history, and showed higher moisture availability below the hard pan in experimental plots with severe drought symptoms, indicating that plants in these plots were not able to penetrate the hard pan (Schulthess et al., pers. comm.). 

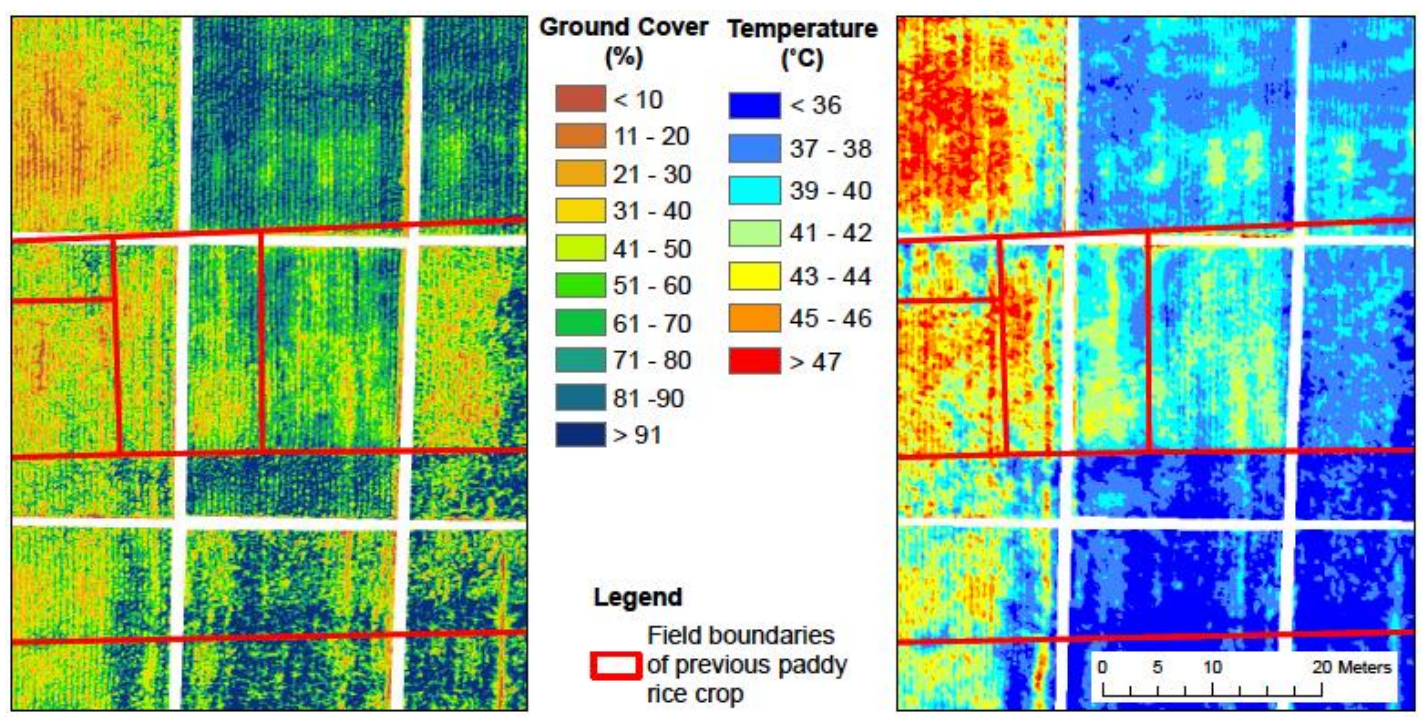

Figure 6. Plots of irrigation experiment near Patuakhali, Bangladesh, in 2015. The nine maize plots had been imposed over several farmers' fields. The hard pans of some of the fields, created for the previous paddy rice crop, were not broken up when preparing the land for the maize experiment. This can be seen for the central plot, where plants suffered from dry conditions in the upper part, resulting in lower ground cover and higher canopy temperature as compared to the lower part of the plot.

The availability of remote sensing data has been greatly improved by recent launches of new public and private remote sensing satellite systems. The combined use of remote sensing and crop simulation models will make management recommendations more dynamic, with the ability to account for actual and forecasted weather conditions (including the prediction of outcomes in different weather years). Smart phones can also help gather information on crop management [5], which then can be used to parameterize model runs. It is already theoretically possible to do this, but practical hurdles remain. The stakes are high, as the input for all model components needs to be accurate and the simulation results reliable.

There is the potential to use specific model components to generate recommendations regarding the timing of crop management activities, i.e., whether nitrogen top dressing or irrigation needs to be conducted earlier, at the same time, or later than usual, as function of actual weather conditions. Similarly, the abovementioned PANI recommendation can be turned into irrigation scheduling recommendations, informing the farmer whether a crop needs to be irrigated in shorter or longer intervals than usual. These kinds of recommendations can be generated without any input from the farmers. The only requirements are a properly calibrated and validated model, and historic and current weather data.

Janssen et al. [303] discuss integrating emerging information and communication technologies with big data sources, and how this can be incorporated into farmer or industry decision making using crop models. The increased access of rural areas to Information Communication Technologies (ICT), reduced costs in satellite imagery acquisition, and cloud- or supercomputer-based analysis for faster processing and delivery (e.g., Descartes Labs daily image analysis), improves the ability of farmers and technicians to use crop modelling tools for day-to-day management decisions.

\section{Modelling Genetic Variability}

\subsection{Crop Simulation Models for Genetic Improvement}

Analysis of interactions between $G$ and $E$, and between $G$ and $E$ and $M$, requires a deep understanding of their biological basis. Mechanistic crop models such as APSIM [304] or Simple Simulation Modelling (SSM) [305] can predict crop performance, based on equations characterizing the 
responses of crop growth and development to environmental cues. These equations are derived from experimental data, making these models both process- and statistics-driven. Therefore, APSIM and SSM provide accurate predictions of crop production in relation to genotype $(\mathrm{G})$, environment (E), soil and management factor $(\mathrm{M})$, while addressing the long-term resource management issues.

Models like APSIM and SSM have successfully predicted growth and yield in chickpea (Cicer arietinum L.) [143,145,306], lentil (Lens culinaris L.) [205,206], bean (Phaseolus vulgaris L.) [307], soybean (Glicine max (Linn.) Merr.) [152], peanut (Arachis hypogaea L.) (Vadez et al., pers. comm.), sorghum (Sorghum bicolor L.) [308], wheat [309], and maize [310-312]. Models can be used to assess the intensity and frequency of water stress patterns, enabling more targeted breeding and agronomic management interventions for specific environments [313,314]. For example, Kholova et al. [151] used APSIM to demonstrate that several genetic traits underlying a staygreen phenotype in sorghum increased grain yield across sorghum production regions in India (Figure 7). Some of these trait modifications resulted in trade-offs between grain and stover productivity. For example, breeding for a smaller leaf canopy reduced pre-anthesis water use, which improved water availability for grain filling and ultimately increased yields, but was at the expense of stover productivity, which is unfavourable for farmers interested in crop residues for fodder [151].



Figure 7. Crop modelling predictions of trait alterations on yield (top chart) in different stress scenarios of a large sorghum growing area in India (bottom map). The top graph shows APSIM predictions of grain yield across five stressed environments in a standard genotype that is insensitive to vapour pressure deficit (VPD; orange bars) and in the same genotype when made sensitive to VPD (green bars). The bottom map shows the areas where introgression of the VPD-sensitivity trait would have the strongest effect (based on the frequency of different stress scenarios in the growing regions), i.e., more in the northern sub-region where the prevalence of severe stress is higher, less so in the two southern sub-regions where the prevalence of mild stress is higher. Adapted from Kholova et al. [151].

In another modelling study, Vadez et al. [143] compared the effects of altering root-related genetic traits on the grain yield of chickpea and found that, while the best genetic trait increased yields by $10 \%$, a modest irrigation of $30 \mathrm{~mm}$ at the beginning of pod filling increased yields by $40 \%$. This illustrates the potential of mechanistic crop models to compare genetic and agronomic options and their importance as decision-making tools in research investments.

Finally, crop models have been used to undertake yield gap analysis and lay out potential options for improving crop productivity at a country level. For instance, Soltani et al. [157] showed that 
chickpea production in Iran could be tripled by using short duration cultivars and applying a single irrigation of $60 \mathrm{~mm}$ at the beginning of pod filling.

\subsection{Genomic Selection Models Incorporating Physiological Traits and Insights}

Genomic selection exploits the within family variance by means of genome-wide molecular markers/sequence data without the need to phenotype the candidates for selection; this saves time and enhances genetic gains and the response to selection per unit of time. While genomic selection models do not require a physiological understanding of the traits of interest, understanding the physiological underpinnings of grain yield can enable the development of new genomic selection approaches with improved accuracies, both within and across environments. A relatively simple way to utilize data on physiological traits is to use multivariate mixed models for prediction. These models enable information to be "borrowed" from relatives and secondary traits that are genetically correlated with the trait of interest. Multivariate prediction models have outperformed univariate prediction models in both animal and plant species [315,316], especially when secondary traits are observed on both the model training and validation sets [317].

The use of multivariate models with aerial measurements of canopy temperature and NDVI as secondary traits on both training and validation sets increased pedigree and genomic selection accuracy for grain yield breeding in optimal, severe drought, and late heat environments in Obregon, Mexico, for both replicated and unreplicated secondary traits (Figure 8) [115]. Across five environments, multivariate models outperformed univariate models by up to $70 \%$ when secondary trait data was not replicated.

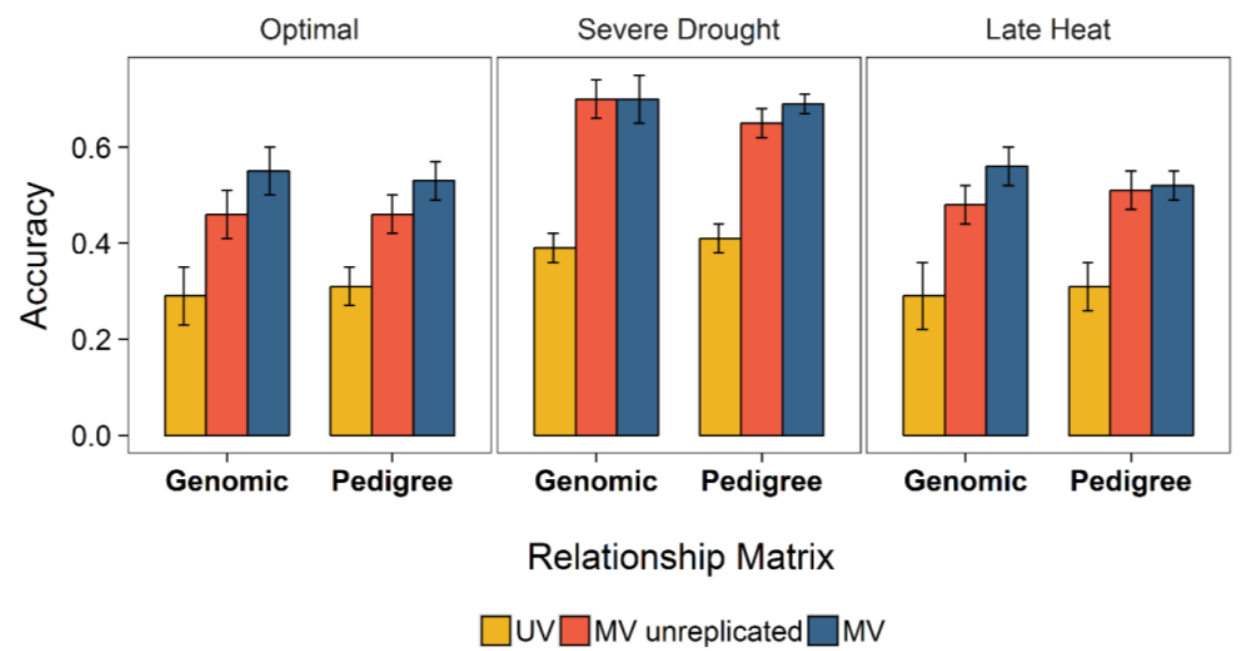

Figure 8. Accuracy of univariate and multivariate genomic prediction models for yield. Comparison of ordinary univariate pedigree and genomic selection model accuracies with those of multivariate pedigree and genomic selection models incorporating either replicated or unreplicated secondary trait data in optimal, severe drought, and late heat environments. (UV = univariate; MV = multivariate). Adapted from Rutkoski et al., 2016 [115].

As described above, physiological trait data could also be potentially used in prediction models that incorporate crop growth models and genome-wide markers to predict breeding candidate performance in untested environments. Physiological trait data has not yet been utilized in such models because the traits utilized in crop growth models are relatively difficult to measure on many individual plants.

Rather than combine crop growth models and genome-wide markers in one, unified model, Heslot et al. [318] used a crop model and weather data to derive stress covariates by growth stage. They then used these stress covariates, along with genome-wide markers, to explain the residuals from genomic prediction using a machine-learning approach. If sufficient phenotypic data were available 
such that crop models could be parameterized for every individual, it would be possible to compute growth stages for each individual in each environment, perhaps improving predictive abilities.

\section{3. $G \times$ E Interactions}

Physiological breeding crosses parents with different complex traits to accumulate alleles associated with yield increases [7]. The strategy is based on testing models of theoretically complementary traits and evaluating selected progeny in multi-location yield trials to inform $\mathrm{G} \times \mathrm{E}$ models. Analysing the performance of new lines developed via physiological breeding helps inform crop design and refine experimental environments, demonstrating which combinations of traits/alleles improve yield, and in which environments [319]. Physiological and genetic dissection of complex traits provides valuable insights; for example, by establishing the genetic bases for trait synergies and trade-offs (e.g., $[320,321])$. Such outputs can inform simulation models that test hypotheses regarding new levels of trait expression and trait combinations across a range of environments [145,322].

Many statistical models have been developed to study $\mathrm{G} \times \mathrm{E}$ for plant breeding. Unlike simulation or process driven models - that are driven by environmental inputs and modified by genotype information-, statistical models are entirely stochastic. Outputs are based on associations among genetic and environmental variables with probability largely determining the significance of conclusions. Statistical models are very flexible and can be designed for almost any data set assuming that error (and other terms as in regression or multivariate analyses) can be modelled effectively.

These models have helped plant breeders assess the stability of economically important traits and predict the performance of newly developed genotypes under various environmental conditions. The development of methods for modelling $G \times$ E precedes the development of analyses of variance, as it could be better modelled by fitting a multiplicative (product) operator than by a sum formula [323]. A simple regression of a line's performance on the environmental mean was first proposed and used by Yates and Cochran [324]. Other models to study $\mathrm{G} \times \mathrm{E}$ are based on the principal component decomposition of matrix $\mathrm{G} \times \mathrm{E}$ [325-329]. Researchers employed the principal component operator for modelling $G \times E$ in the context of linear mixed-effect models [330-332], while others evaluated using structured co-variance matrices to model $\mathrm{G} \times \mathrm{E}$ in the context of pedigree-based mixed models for estimating the breeding values [333-335].

The models mentioned above do not attempt to identify genetic causes of $G \times E$ in the chromosome by decomposing total $\mathrm{G} \times \mathrm{E}$ into chromosome regions or specific genes. However, differences between individuals can be explained by regressing phenotypes on molecular markers, and differences between environments can be evaluated by regressing phenotypes on a reduced number of environmental covariates (e.g., temperature, precipitation, soil moisture, solar radiation). By combining information on individual genomes (e.g., molecular markers) with environmental covariables, it is possible to account for $\mathrm{G} \times \mathrm{E}$. An example of such an approach is the ordinary least squared factorial regression model [336-339].

One advance in using statistical approaches in breeding models was developed by Yin et al. [340]. Their concept was that variety-specific parameters could be linked to genetic information through QTL (quantitative trait loci) and eventually a specific part of the genome. In breeding programs, varieties can be characterized using QTLs, enabling $\mathrm{G} \times \mathrm{E}$ to be predicted through crop models. Working with the common bean, Hwang et al. [341], established dynamic QTL effect models for node addition rate, daily rate of progress from emergence toward flowering, and daily maximum main stem node number.

As modern genotyping and sequencing technologies develop, molecular marker information has become highly dimensional. The number of markers now greatly exceeds the number of data-points available for model fitting, posing important statistical and computational challenges. However, whole-genome regression methods allow information about hundreds of thousands of markers to be jointly considered [342]. Such models capture major-effect genes, as well as genomic regions with small effects. Environmental information is also becoming highly dimensional due to information 
systems that allow continuous monitoring of environmental climatic conditions. Previous models cannot cope with the highly dimensional nature of genomic and $\mathrm{E}$ information.

Standard genomic selection models were recently extended to multi-environment settings. For instance, Burgueño et al. [343] used a multi-environment version of the Genomic BLUP (GBLUP), modelling $\mathrm{G} \times \mathrm{E}$ using genetic correlations, and found that the multi-environment GBLUP had a much higher prediction accuracy than the single-trait GBLUP. Meanwhile Jarquin et al. [344] proposed a model where the main effects of, and interactions between, markers and environmental covariates are introduced. Recently, Lopez-Cruz et al. [345] proposed a marker $\times$ environment interaction model where marker effect and genomic values are partitioned into components that are stable across environments (main effects), and others that are environment-specific (interactions). This interaction model is useful when selecting for stability and adaptation to target environments. Genomic prediction accuracy consistently and substantially increased when incorporating $\mathrm{G} \times \mathrm{E}$ and marker $\times$ environment interactions.

\section{4. $G \times E \times M$ Interactions}

$\mathrm{G} \times \mathrm{E} \times \mathrm{M}$ interactions are difficult to model with precision, particularly when extrapolating to new environments and genotypes. The challenges have been highlighted by the work of the AgMIP Wheat group, who showed the uncertainty encountered when comparing 30 different models; nevertheless, multi-model ensembles with more robust predictions have been developed [346]. A powerful innovation will be to encompass the following types of approaches into crop simulation modelling for more robust outputs:

- Statistical modelling of $\mathrm{G} \times \mathrm{E} \times \mathrm{M}$ (and lower order interactions) as a stochastic tool for testing specific elements of simulation models and to parameterize or calibrate input variables;

- Genomic selection models using high density molecular markers to parameterize G and thus test the value of specific genomic regions and make predictions in different target environments [115];

- Physiological breeding models to test different combinations of traits and alleles through strategic crossing and progeny testing in well-defined target environments [7];

- Testing of $G \times M$ interactions, which lend well to reductionist research approaches because - unlike $\mathrm{E}$, which is infinitely variable in the field- $\mathrm{M}$ can be varied for one or more factor within a single $\mathrm{E}$.

Montesinos-Lopez et al. [347] recently developed the theory of a Bayesian three-way, multi-trait, multi-environment genomic model. The proposed Bayesian model (with unstructured variance-covariance) was evaluated on two datasets and improved prediction accuracy, compared to the model with diagonal and identity variance-covariance structures [347]. The three-way Bayesian genomic interaction model uses genomic and/or pedigree information and could be extended to include more factors, potentially making it applicable for assessing $\mathrm{G} \times \mathrm{E} \times \mathrm{M}$ and $\mathrm{G} \times \mathrm{E} \times \mathrm{M} \times \mathrm{S}$ in the context of crop modelling.

Intercropping is a well-known practice in Africa that is reported to have advantages over mono cropping through several mechanisms. To analyse the performance of intercropping systems, crop simulation models can be helpful to identify those mechanisms in such a complex cropping system. The first ecophysiological model for interplant competition INTERCOM was developed by Kropff and van Laar [17] at IRRI and Wageningen University and was well documented with first applications in crop weed systems. The model has subsequently been used in several systems for intercropping in Africa, Switzerland, China and the Netherlands. In Africa, with AfricaRice and Wageningen University, the model was used to identify the optimum relay crop in rice systems with a highly competitive (Cajanus c.) and a not competitive species (Stylosanthus spp.) where it was found that relay cropping with the competitive species was highly beneficial when late sown. This was a very interesting counter intuitive result [60,62]. Intercropping model versions have been developed by the APSIM teams as well and have been used for agroforestry systems [348]. However intercropping 
modelling has not moved to the level of intensively used decision support systems yet. As solutions are being sought for many issues in relation to sustainable agricultural systems in Africa in relation to climate change and new upcoming pests and diseases, the intensification of the use of intercrops and research to improve them through crop models such as INTERCOM may be very useful to enhance the agronomic research effort.

\section{Modelling Socioeconomic Factors}

\subsection{Bio-Economic Modelling}

Bio-economic modelling dates to the 1990s and includes mathematical programming models [284,294,295,349,350], multi-agent models [351-353], and other simulation models [291,354]. These models are sometimes combined with econometric analyses that fine-tune the results. Linking the results of crop models to these lower aggregation level models requires the determination of relevant adjustment factors, depending on the issues being addressed. For instance, if biotic stress in the analysis is linked to certain weather patterns and stochastic probabilities of occurrence, the crop growth model output needs to be combined with disease progress curves and damage functions to adequately account for biotic stress. While many of these bio-economic models focus on crop production, a number also take into account crop-livestock interactions [195,197,294,355].

Household survey data on actual yields and management practices can be used to develop specific, reduced form models that estimate yield reducing factors for non-optimal input levels. However, the use of reduced form models in econometric analyses of overall farm household behaviour poses difficulties for soft-coupling with crop model outcomes, and may be better analysed using structural models. The difference between econometrically estimated models of farm household behavior and structural models is that the structural models such as the bio-economic models highlighted in the previous paragraph, describe the behavior as structural equations in mathematical terms, whereas the reduced form models provide only the statistical associations between measured inputs into the decision making process and the measured outputs in terms of key indicators [282].

At higher levels of aggregation, integrated assessment models can illuminate interactions between climate and socioeconomic global drivers. Models such as IMPACT [86,356], the International Agricultural Prospects Model [357], and MAGNET [358,359] have demonstrated their usefulness in exploring these interactions. Global economic models have been assessed within AgMIP [2,90,360,361] and this approach will soon be applied to micro-level models. This allows models to be improved and fine-tuned to better answer questions related to the socioeconomic factors associated with technology change in agriculture.

Within the CGIAR for example, a joint study by CIMMYT and IFPRI [89] implemented a spatially-explicit bio-economic modelling framework, incorporating the CERES-Wheat model in DSSAT and a farm-level profitability analysis of local wheat production. This integrated framework assessed the economic viability of potential wheat expansion in 12 countries across sub-Saharan Africa, and found that they are using less than $10 \%$ of their potential area for profitable local production. This type of approach can be utilised on a regional or global scale by agricultural ministries and funding agencies to help determine potential returns on investments.

\subsection{Foresight Analysis}

Foresight analysis is an important instrument for monitoring and enhancing our understanding of the evolving context in which agricultural systems operate. Given the research-to-adoption lag, the needs of future beneficiaries should inform current priorities, while also considering likely biophysical, socioeconomic, and politico-institutional contexts at the time when technologies (including varietal improvement) come to fruition. Both beneficiaries' needs and the context in which they operate are shaped by global drivers of change, pressures, and events. The primary global drivers of change are climate change, demographic developments, and global economic development. Secondary drivers 
of change include migration, urbanization, shifting gender roles, resource depletion, technological convergence, and changing political environments. Pressures resulting from these global drivers include pollution; decreases in natural ecologies; land degradation (and the resulting changes in environmental productivity); health related issues, from chronic malnutrition to obesity; and unequal wealth and income distribution. Events are major occurrences with global or regional effects. These events are difficult to accurately predict, but their occurrence is both probable and plausible at any given time. They can include weather extremes (e.g., droughts, floods, and the El Niño phenomenon); geophysical disasters (earthquakes and volcanic eruptions); outbreaks of new biotic stresses (such as recent outbreaks of maize lethal necrosis and rust in east Africa, and wheat blast in Bangladesh); economic shocks (such as steeply rising food prices); and political and social unrest. One positive factor that holds the middle ground between a driver and an event is disruptive technology. A clear example of a disruptive technology is the Green Revolution, which lies at the foundation of the CGIAR.

These drivers, pressures, and events are forcing farmers, civil societies, and countries to reassess priorities and interventions. The primary effect is the change in agro-ecological production potential (related to climate change) and the comparative advantage of different crops in different locations (linked to long-term trends in commodity prices).

Using a wide range of models and approaches across different scientific disciplines when analysing of the effects of global drivers, pressures, and events, improves our ability to realize potential opportunities, while responding in a timely fashion to avoid major food security crises. For example, to assess the potential role of agricultural technologies and innovations in foresight modelling studies, IFPRI's IMPACT model incorporates the DSSAT Cropping System Model to simulate grid cell-specific crop yield responses to scenarios of changes in technology adoption and environmental conditions, and uses this information to simulate their long-term implications on international food trade, food security, and markets [95].

Rosegrant et al. [92] used this analytical framework to assess the potential role of 12 promising technologies on international food trade, food security, and natural resources in 2050. The authors developed an integrated economic modelling framework with DSSAT, where the models of maize, rice, and wheat were modified to simulate technologies not previously implemented in the model (e.g., effects of anthesis-silking interval to simulate drought tolerance trait of maize). Another example is the analysis of climate change on future maize production. Tesfaye et al. [112] showed that climate change will affect maize yields across sub-Saharan Africa in the future (2050 and 2080), and that the extent of the impact at a given period will vary considerably between input levels, regions, and maize mega-environments. These effects may have a negative impact on maize consumption and daily calorie intake, though Rosegrant et al. [356] showed that international trade has the potential to offset some of the negative impacts. These analyses that build on the IMPACT model and use gridded crop models [93,362], in combination with socioeconomic models, have helped focus breeding efforts on specific abiotic stresses.

\subsection{Case Study: Calculating Food Systems Risks}

Global insurance company Lloyd's of London released a peer-reviewed, industry approved 2015 study on the impacts of acute disruption to the global food supply [363]. Experts considered how weather-related events can disrupt the food supply, and can be exacerbated by additional political and economic risks in a chain-like reaction. Their scenario was based on a strengthened warm phase of the El Niño climate pattern, which would generate flooding and drought in different locations across the globe, as well as winds that spread the Ug99 wheat stem rust across a wide territory (Figure 9). Shock scenarios were developed and explored using the IFPRI IMPACT model, which gives a rough interpretation of weather changes leading to drought at a large grid level. Lloyd's model was constructed by de-trending globally aggregated FAO data from 1961 to 2013 to identify probable changes in crop area and yield. It should be noted that the estimated production response to the shock was deemed drastic but plausible by the authors (Further detail on assumptions about 
responses at the country level is included in the report, including production loss, trade restriction mechanisms, social instability, and currency fluctuations. The report authors note that "the probability of occurrence is estimated as significantly higher than the benchmark return period of 1:200 years applied for assessing insurers' ability to pay claims against extreme events", ([363], p. 19)). The effects emulate recent country-level effects on major crops, such as maize in southern Africa, where major yield losses have been observed. An improved modelling system with more detailed grid data and more sophisticated crop models could deliver better insight, though more data on soils and weather conditions are essential to make progress in the explorative capacity of the approaches.

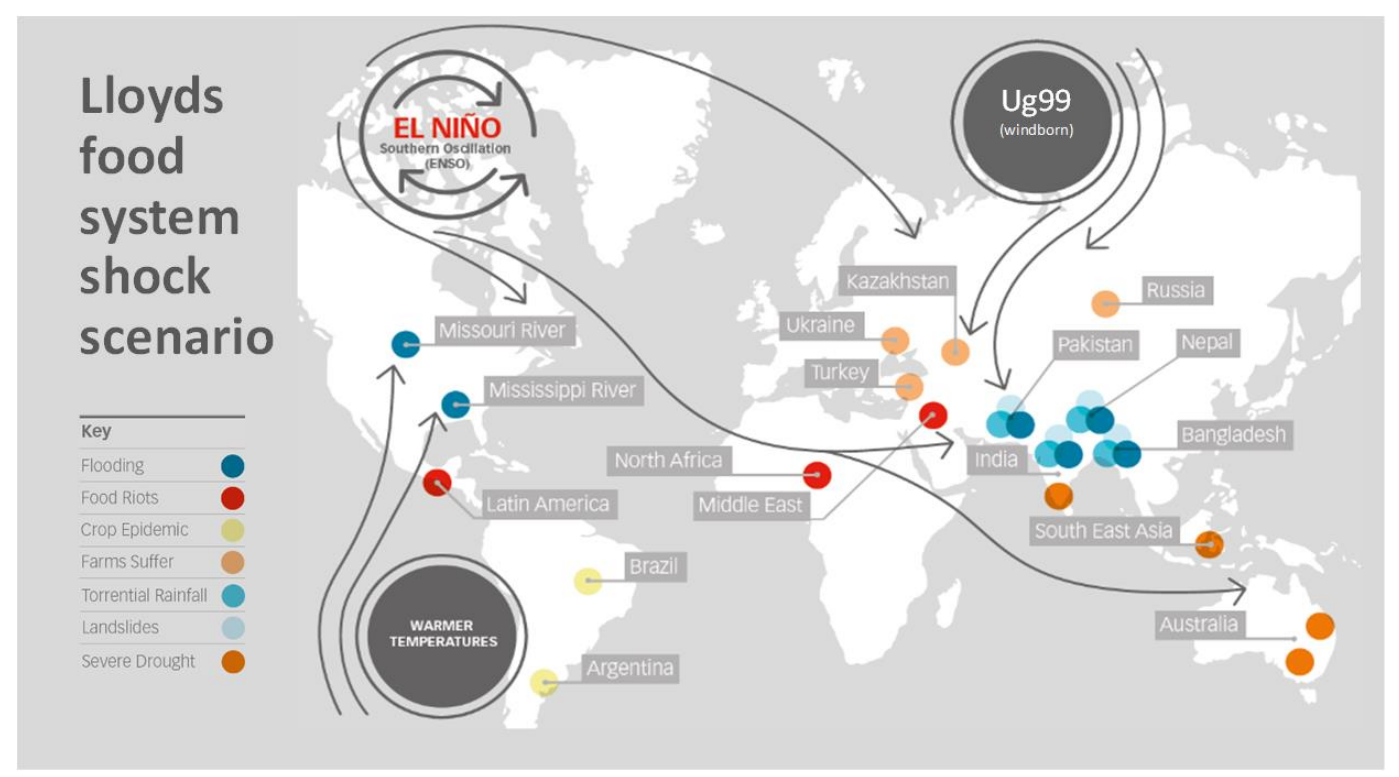

Figure 9. Plausible scenario of a food systems shock. The Lloyd's report aids crop modellers by clarifying the likely impacts of a plausible sudden food supply shock due to simultaneous occurrence of both biotic and abiotic stress on supply chains and societies [363]. Adapted from Lloyd's report with the permission from the authors.

According to the IMPACT bio-economic model, production shocks would generate global losses of $7 \%$ for wheat, $10 \%$ for maize, $11 \%$ for soybeans, and $7 \%$ for rice (Figure 10 ). This would generate a quadrupling of prices for the first three crops, and a five-fold increase for rice. The impacts would extend deep into society, creating humanitarian crises where food shortages arise. Moreover, stock markets would be de-stabilized, with their values estimated to fall by $10 \%$ in Europe and $5 \%$ in the USA.

While Lloyd's report is a forecasting exercise, not a prediction, it underscores the fragility of the food system, its global interconnectedness, and its central role in maintaining social stability. Moreover, the complexity of socio-ecological systems confirms that crop modellers have a key role to play in understanding and preparing for major food supply disruptions. 


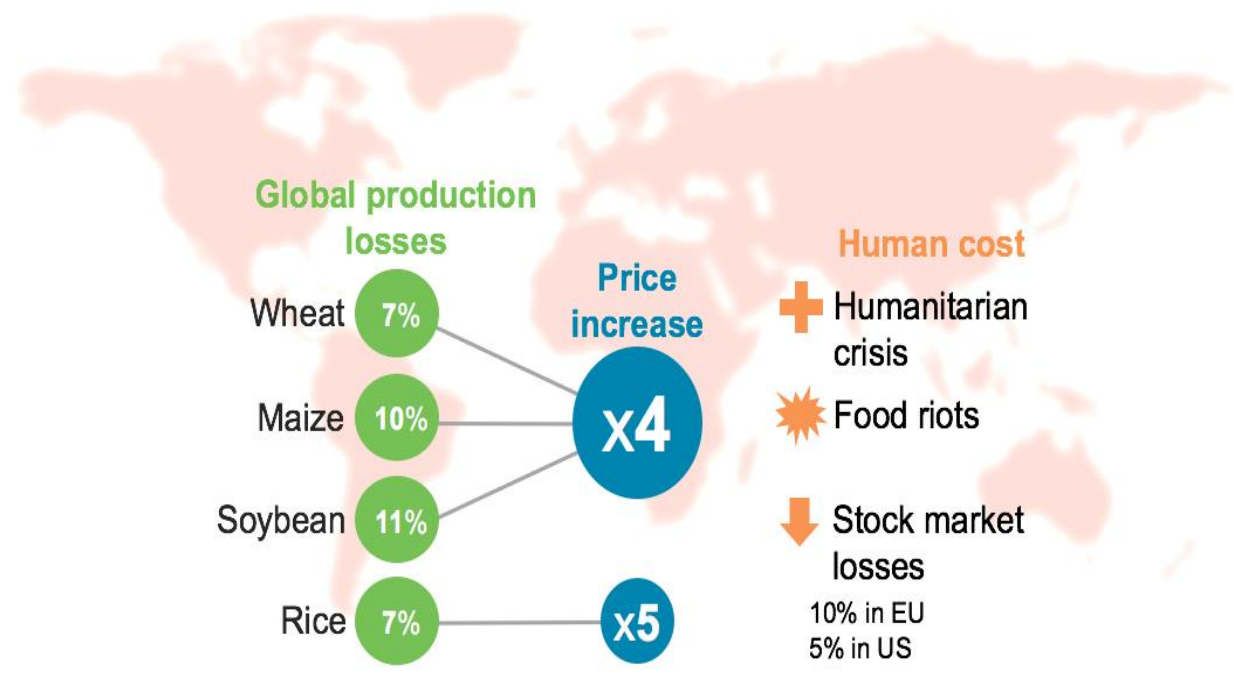

Figure 10. Supply chain and societal impacts of a plausible food systems shock. The Lloyd's study [363] found that the impact of such a weather event would be serious and widespread. Adapted from Lloyd's report with the permission from the authors.

\section{Increasing the Availability of Data and Its Value in Modelling}

\subsection{Global Phenotyping Networks}

To be credible and useful, crop simulations must hold true across a wide range of environments. They would therefore benefit immeasurably from global phenotyping networks that characterize breeding materials in key ecologies using harmonized protocols [13]. Such networks can capitalize on existing infrastructure, but there is often a need for investment to ensure greater control of experimental treatments (Table 2) and of trait measurement (e.g., [364]). A networking approach has already been applied to initiatives such as Drought Tolerant Maize for Africa and Improved Maize for African Soils, and in the use of field phenotyping tools provided by various organizations and developed for ground and aerial sensing (e.g., [365]). Various phenotyping initiatives have emerged recently (e.g., International Plant Phenotyping Network, European Plant Phenotyping Network, North American Plant Phenotyping Network, Wheat Initiative, etc.) that could help promote common standards, at least within crops. The added value of high-throughput phenotyping methods (e.g., [366]) is recognized, as is their generic applicability for measuring many high priority traits across major cereal crops [250]. As a relatively new field, high-throughput phenotyping lends itself well to the introduction of common standards. Some generic standards for field phenotyping platforms to support simulation modelling are presented in Table 2.

\subsection{Data Sharing and Standardization}

All the modelling approaches outlined here could be strengthened by validation from independent datasets. Many institutions-including CGIAR — are increasingly obliged to openly share research data. Aside from helping avoid redundancy and adding robustness to datasets, more widespread sharing of data enables modelling to take place on a larger scale (e.g., [367]). Broad agreement on core datasets, measurement protocols, and standardization of experimental treatments and definitions could exponentially increase the power of shared data $[12,250]$. To simulate plant growth in models, the minimum information required includes daily weather data, soil characterization, basic agronomic inputs, and at least two measures of biomass, while more detailed and time-consuming measurements vary from model to model [250]. Better environmental data is required from many more countries if the effects of climate change are to be predicted [368].

The limited availability of large-scale, interoperable datasets is recognized as bottleneck to the use of crop modelling and, more broadly, agricultural systems modelling [5]. CGIAR centres manage data 
from multiple crops and locations, much of which is collated within the AgTrials database. CGIAR collaborations result in a vast quantity of data; the International Wheat Improvement Network alone has collected over 20 million raw phenotypic data points [369]. Such datasets, strengthened by the ideas on platforms and standardization described above, present enormous opportunities for crop modelling, but greater investment is required to effectively automate data extraction from different databases. The CGIAR Platform for Big Data in Agriculture was launched in 2017 with the explicit purpose of making CGIAR datasets findable, accessible, interoperable and reusable (FAIR). The platform brings together CGIAR, academia, and other actors from public and private sector and civil society to harness the capabilities of big data to enhance the impact of international agricultural research. One recent progress from the platform to help filling the data gap has been the development of the open access, searchable data harvester GARDIAN (Global Agriculture Research Data Innovation and Acceleration Network), which enables the discovery of agricultural datasets and publications across the CGIAR system and beyond.

A global "science commons" attitude should also be encouraged (for both public entities and private organizations), at least for non-propriety items like E data and generic responses of crops to E and $\mathrm{M}$ factors. Funding bodies could facilitate timely sharing of data by investing more explicitly in research publication, with the condition of public access [13]. Such interventions could also result in more thorough reporting of experimental treatments and conditions by researchers, as well as greater availability of datasets that are normally not written up.

\section{Conclusions}

Moving forward, we propose the following developments for the crop modelling field:

1. New insights into the biology of plant development and response to environmental cues will naturally enable model development, as it becomes possible to incorporate additional functions into the main algorithms of models. While this will contribute to a continuous improvement, it contains an inherent risk of making models so complex that they lose their initial purpose of being a simpler representation of the reality, but not the reality itself. A recent paper by Soltani and Sinclair [309] illustrates the value of keeping models simple. While continuous improvements to the science of crop models are critical, there should be a balance between the level of complexity and approximation of the processes they model.

2. While crop models are primarily being developed and used as scientific research tools, their stakeholders extend far beyond research institutions to include farmers, policymakers, development practitioners, and the private sector. Maintaining close links with this international community is a crucial part of developing and applying models, and one where CGIAR centres can play a major role through their network of public and private sector partners at all levels. Coordinated linkages between stakeholders will help define the crop modelling community's priorities and stimulate further development in the modelling science, as well as transparently communicate the capacity and caveats of crop modelling approaches. For example, crop models are increasingly equipped to provide stochastic estimates of crop growth and yields (e.g., Yield Prophet ${ }^{\circledR}$ ) and potential impacts of altering specific genetic or agronomic traits (e.g., [370]). Meanwhile, foresight studies increasingly incorporate crop models and couple them with large-scale economic models to address questions from policymakers on the potential impacts of global change scenarios.

3. Scientists, including many working in CGIAR Centres, are progressively picking robust and complex methods from advanced mathematics, computer science, and physics principles to address the challenges outlined in this review. Artificial neural networks and cellular automata, coupled with fuzzy logic percolation and individual/agent-based approaches, are among the modelling methods being applied to improving crop management (Figure 2). Artificial neural networks are a system inspired by the functioning of neural networks of animal brains [371]. Its main advance is that it permits the use of data collected at any suitable scale, bypassing the 
ambiguities that can occur when fitting equations to estimated parameters [371]. Meanwhile cellular automate is a spatially and temporally discrete modelling concept that describes the dynamics through interactions and synchronous evolution using elements such as grid of cells, states, neighbourhood, transition rules, and time step [372]. This approach, when coupled with fuzzy logic (i.e., representation of the level of truth with scaled values from 0 and 1), yields a robust model capable of incorporating vague and imprecise knowledge to guide and improve pest management [372].

4. As great strides are made in harnessing the genotypic information of more and more traits, the potential exists to interface a layer of genetic information within crop coefficients. Crop coefficient(s), leading to a specific response, could be driven by QTL with a value of putative effect. This kind of progress would theoretically enable the prediction of ideotype performance, based on marker content [373-375]. However, more knowledge is needed to better understand epistatic interactions and their role in determining phenotypes.

5. Genomic selection is increasingly being used to select promising recombinants, based on their marker content. Genomic selection has shown that breeding can be done saving time and money and thus improving the genetic gains. Crop models could therefore be interfaced to deal with the portion of the phenotypic variance that is accounted for by these interactions.

6. The $\mathrm{G} \times \mathrm{E} \times \mathrm{M} \times \mathrm{S}$ paradigm offers scope to address the complexities of agri-food systems, using data and models, without falling into the trap of over-simplification, inherent in modelling, by harnessing data and tools across multiple scientific disciplines and thus, enhancing the potential for creating impact for the target beneficiaries of the CGIAR.

Designing intelligent agri-food systems is central to meeting global development challenges. The renewed focus on the systems-level has created significant opportunities for modellers to participate in enhancing the impact of science on development. However, a coherent approach-based on principles of transparency, cooperation, and innovation-is essential to achieve this. Modelling is the best tool we have for grasping the big picture and truly comprehending how the whole is greater than the sum of its parts. Millions of farmers, and the societies that depend on their production, are relying on us to step up to the plate.

Author Contributions: Conceptualization, M.R. and M.K., Writing-Original draft preparation M.R., M.K., J.C., J.K., G.K., J.R., U.S., B.-S., K.S., H.T. and V.V., Writing-Review and Editing, A.M.M., K.S. and M.R.

Funding: This research received no external funding.

Acknowledgments: The authors would like to express their gratitude to USAID and to the donors to the CGIAR System Council. This work was supported by the CGIAR research programs (CRPs) on RICE, MAIZE and WHEAT agri-food systems, the CGIAR Platform for Big Data in Agriculture and Excellence in Breeding. The contents and opinions expressed herein are those of the authors and do not necessarily reflect the views of the associated and/or supporting institutions. The usual disclaimer applies.

Conflicts of Interest: The authors declare no conflict of interest.

\section{References}

1. Grassini, P.; Eskridge, K.M.; Cassman, K.G. Distinguishing between yield advances and yield plateaus in historical crop production trends. Nat. Commun. 2013, 4, 2918. [CrossRef] [PubMed]

2. Wiebe, K.; Lotze-Campen, H.; Sands, R.; Tabeau, A.; Van Der Mensbrugghe, D.; Biewald, A.; Bodirsky, B.; Islam, S.; Kavallari, A.; Mason-D'croz, D.; et al. Climate change impacts on agriculture in 2050 under a range of plausible socioeconomic and emissions scenarios. Environ. Res. Lett. 2015, 10, 085010. [CrossRef]

3. Rosegrant, M.W.; Tokgoz, S.; Bhandary, P. The new normal? A tighter global agricultural supply and demand relation and its implications for food security. Am. J. Agric. Econ. 2013, 95, 303-309. [CrossRef]

4. Fischer, R.A.; And, D.B.; Edmeades, G.O. Crop Yields and Global Food Security: Will Yield Increase Continue to Feed the World? Australian Centre for International Agricultural Research: Canberra, Australia, 2014; ISBN 978-1-925133-06-6. 
5. Antle, J.M.; Basso, B.; Conant, R.T.; Godfray, H.C.J.; Jones, J.W.; Herrero, M.; Howitt, R.E.; Keating, B.A.; Munoz-Carpena, R.; Rosenzweig, C.; et al. Towards a new generation of agricultural system data, models and knowledge products: Design and improvement. Agric. Syst. 2017, 155, 255-268. [CrossRef]

6. Hodson, D.; White, J. GIS and Crop Simulation Modelling Applications in Climate Change Research. Clim. Chang. Crop Prod. 2010, 1, 245-262. [CrossRef]

7. Reynolds, M.; Langridge, P. Physiological breeding. Curr. Opin. Plant Biol. 2016, 31, 162-171. [CrossRef] [PubMed]

8. CIAT; IFPRI. CGIAR Big Data Coordination Platform. Leveraging CGIAR Data: Bringing Big Data to Agriculture, and Agriculture to Big Data; Proposal to the CGIAR Fund Council; International Center for Tropical Agriculture (CIAT): Cali, Colombia; International Food Policy Research Institute: Washington, DC, USA, 2016.

9. Bassu, S.; Brisson, N.; Durand, J.L.; Boote, K.; Lizaso, J.; Jones, J.W.; Rosenzweig, C.; Ruane, A.C.; Adam, M.; Baron, C.; et al. How do various maize crop models vary in their responses to climate change factors? Glob. Chang. Biol. 2014, 20, 2301-2320. [CrossRef]

10. Rosenzweig, C.; Jones, J.W.; Hatfield, J.L.; Ruane, A.C.; Boote, K.J.; Thorburn, P.; Antle, J.M.; Nelson, G.C.; Porter, C.; Janssen, S.; et al. The Agricultural Model Intercomparison and Improvement Project (AgMIP): Protocols and pilot studies. Agric. For. Meteorol. 2013, 170, 166-182. [CrossRef]

11. Ruane, A.C.; Hudson, N.I.; Asseng, S.; Camarrano, D.; Ewert, F.; Martre, P.; Boote, K.J.; Thorburn, P.J.; Aggarwal, P.K.; Angulo, C.; et al. Multi-wheat-model ensemble responses to interannual climate variability. Environ. Model. Softw. 2016, 81, 86-101. [CrossRef]

12. White, J.W.; Hunt, L.A.; Boote, K.J.; Jones, J.W.; Koo, J.; Kim, S.; Porter, C.H.; Wilkens, P.W.; Hoogenboom, G. Integrated description of agricultural field experiments and production: The ICASA Version 2.0 data standards. Comput. Electron. Agric. 2013, 96,1-12. [CrossRef]

13. Reynolds, M.P.; Braun, H.J.; Cavalieri, A.J.; Chapotin, S.; Davies, W.J.; Ellul, P.; Feuillet, C.; Govaerts, B.; Kropff, M.J.; Lucas, H.; et al. Improving global integration of crop research. Science 2017, 357, 359-360. [CrossRef] [PubMed]

14. Jones, J.W.; Antle, J.M.; Basso, B.; Boote, K.J.; Conant, R.T.; Foster, I.; Godfray, H.C.J.; Herrero, M.; Howitt, R.E.; Janssen, S.; et al. Brief history of agricultural systems modeling. Agric. Syst. 2017, 155, 240-254. [CrossRef] [PubMed]

15. Whisler, F.D. Sensitivity Tests of the Crop Variables in Ricemod; IRRI Research Paper Series; International Rice Research Institute: Los Baños, Philippines, 1983; 14p.

16. Kropff, M.J.; Cassman, K.G.; Van Laar, H.H.; Peng, S. Nitrogen and yield potential of irrigated rice. Plant Soil 1993, 155-156, 391-394. [CrossRef]

17. Kropff, M.J.; van Laar, H.H.; CAB International; International Rice Research Institute. Modelling Crop-Weed Interactions; Kropff, M.J., van Laar, H.H., Eds.; CAB International: Wallingford, UK; International Rice Research Institute: Los Banos, Philipines, 1993; ISBN 9712200388.

18. Kropff, M.J.; Van Laar, H.H.; Matthews, R.B. ORYZA1: An Ecophysiological Model for Irrigated Rice Production; DLO-Research Institute for Agrobiology and Soil Fertility: Wageningen, The Netherlands, 1994; ISBN 9073384230.

19. Wopereis, M.C.S.; Bouman, B.A.M.; Kropff, M.J.; ten Berge, H.F.M.; Maligaya, A.R. Water use efficiency of flooded rice fields I. Validation of the soil-water balance model SAWAH. Agric. Water Manag. 1994, 26, 277-289. [CrossRef]

20. Kropff, M.J.; Teng, P.S.; Rabbinge, R. The challenge of linking pest and crop models. Agric. Syst. 1995, 49, 413-434. [CrossRef]

21. Matthews, R.B.; Kropff, M.J.; Bachelet, D.; Van Laar, H.H. (Eds.) Modeling the Impact of Climate Change on Rice Production in Asia; CAB International, in association with IRRI: Wallingford, UK, 1995; ISBN 0-85198-959-4.

22. Aggarwal, P.K.; Kropff, M.J.; Cassman, K.G.; Berge, H.F.M. Simulating genotypic strategies for increasing rice yield potential in irrigated, tropical environments. Field Crops Res. 1997, 51, 5-17. [CrossRef]

23. Kropff, M.J.; Teng, P.; Aggarwal, P.K.; Bouma, J.; Bouman, B.A.M.; Jones, J.W.; Van Laar, H.H. Applications of Systems Approaches at the Field Level. Volume 2: Proceedings of the Second International Symposium on Systems Approaches for Agricultural Development, held at IRRI, Los Baños, Philippines, 6-8 December 1995, 1st ed.; Springer: Cham, Switzerland, 1997; ISBN 978-0-7923-4286-1. 
24. Teng, P.S.; Kropff, M.J.; Ten-Berge, H.F.M.; Dent, J.B.; Lansigan, F.P.; Van-Laar, H.H. Applications of Systems Approaches at the Farm and Regional Levels. Volume 1: Proceedings of the Second International Symposium on Systems Approaches for Agricultural Development, held at IRRI, Los Banos, Philippines, 6-8 December 1995, 1st ed.; Springer: Cham, Switzerland, 1997; ISBN 9789401062787.

25. Dingkuhn, M.; Sow, A.; Samb, A.; Diack, S.; Asch, F. Climatic determinants of irrigated rice performance in the Sahel-I. Photothermal and micro-climatic responses of flowering. Agric. Syst. 1995, 48, 385-410. [CrossRef]

26. Dingkuhn, M.; Miezan, K.M. Climatic determinants of irrigated rice performance in the Sahel-II. Validation of photothermal constants and characterization of genotypes. Agric. Syst. 1995, 48, 411-433. [CrossRef]

27. Dingkuhn, M. Climatic determinants of irrigated rice performance in the Sahel-III. Characterizing environments by simulating crop phenology. Agric. Syst. 1995, 48, 435-456. [CrossRef]

28. Dingkuhn, M. Modelling concepts for the phenotypic plasticity of dry matter and nitrogen partitioning in rice. Agric. Syst. 1996, 52, 383-397. [CrossRef]

29. Dingkuhn, M.; Sow, A. Potential yields of irrigated rice in the Sahel. In Irrigated Rice in the Sahel: Prospects for Sustainable Development; Springer: Dordrecht, The Netherlands, 1997; pp. 311-326.

30. Asch, F.; Dingkuhn, M.; Wopereis, M.C.S.; Dörffling, K.; Miézan, K. A conceptual model for sodium uptake and distribution in irrigated rice. In Applications of Systems Approaches at the Field Level. Systems Approaches for Sustainable Agricultural Development; Kropff, M.J., Teng, P.S., Aggarwal, P.K., Bouma, J., Bouman, B.A.M., Jones, J.W., van Laar, H.H., Eds.; Springer: Dordrecht, The Netherlands, 1997; pp. 201-217, ISBN 978-90-481-4763-2.

31. Sié, M.; Dingkuhn, M.; Wopereis, M.C.; Miezan, K. Rice crop duration and leaf appearance rate in a variable thermal environment.: I. Development of an empirically based model. Field Crops Res. 1998, 57, 1-13. [CrossRef]

32. Sié, M.; Dingkuhn, M.; Wopereis, M.C.S.; Miezan, K.M. Rice crop duration and leaf appearance rate in a variable thermal environment. II. Comparison of genotypes. Field Crops Res. 1998, 58, 129-140. [CrossRef]

33. Sié, M.; Dingkuhn, M.; Wopereis, M.C.S.; Miezan, K.M. Rice crop duration and leaf appearance rate in a variable thermal environment. III. Heritability of photothermal traits. Field Crops Res. 1998, 58, 141-152. [CrossRef]

34. Dingkuhn, M.; Asch, F. Phenological responses of Oryza sativa, O. glaberrima and inter-specific rice cultivars on a toposquence in West Africa. Euphytica 1999, 110, 109-126. [CrossRef]

35. Boote, K.J.; Jones, J.W.; Singh, P. Modeling growth and yield of groundnut. In Groundnut—A Global Perspective: Proceeding of an International Workshop, 25-29 November 1991, ICRISAT Asia Centre; ICRISAT: Patancheru, Andhra Pradesh, India, 1992; pp. 331-343.

36. Singh, P.; Boote, K.J.; Yogeswara Rao, A.; Iruthayaraj, M.R.; Sheikh, A.M.; Hundal, S.S.; Narang, R.S.; Singh, P. Evaluation of the groundnut model PNUTGRO for crop response to water availability, sowing dates, and seasons. Field Crops Res. 1994, 39, 147-162. [CrossRef]

37. Singh, P.; Virmani, S.M. Modeling growth and yield of chickpea (Cicer arietinum L.). Field Crops Res. 1996, 46, 41-59. [CrossRef]

38. Hoogenboom, G.; White, J.W.; Jones, J.W.; Boote, K.J. BEANGRO: A process-oriented dry bean model with a versatile user interface. Agron. J. 1994, 86, 182-190. [CrossRef]

39. Hoogenboom, G.; White, J.W.; Jones, J.W.; Boote, K.J. A new and improved dry bean simulation model: CROPGRO-dry bean. Bean Improv. Coop. Annu. Rep. 1995, 38, 15-16.

40. Acosta-Gallegos, J.A.; Vargas-Vázquez, M.L.P.; White, J.W. Effect of sowing date on the growth and seed yield of common bean (Phaseolus vulgaris L.) in highland environments. Field Crops Res. 1996, 49, 1-10. [CrossRef]

41. Elings, A.; White, J.W.; Edmeades, G.O. Options for breeding for greater maize yields in the tropics. Dev. Crop Sci. 1997, 25, 155-168. [CrossRef]

42. Alagarswamy, G.; Singh, P.; Hoogenboom, G.; Wani, S.P.; Pathak, P.; Virmani, S.M. Evaluation and application of the CROPGRO-Soybean simulation model in a Vertic Inceptisol. Agric. Syst. 2000, 63, 19-32. [CrossRef]

43. Naab, J.B.; Singh, P.; Boote, K.J.; Jones, J.W.; Marfo, K.O. Using the CROPGRO-peanut model to quantify yield gaps of peanut in the Guinean Savanna zone of Ghana. Agron. J. 2004, 96, 1231-1242. [CrossRef] 
44. Bhatia, V.S.; Singh, P.; Wani, S.P.; Rao, A.K.; Srinivas, K. Yield Gap Analysis of Soybean, Groundnut, Pigeonpea and Chickpea in India Using Simulation Modeling; International Crops Research Institute for the Semi-Arid Tropics (ICRISAT): Patancheru, Andhra Pradesh, India, 2006.

45. Bhatia, V.S.; Singh, P.; Wani, S.P.; Chauhan, G.S.; Rao, A.V.R.K.; Mishra, A.K.; Srinivas, K. Analysis of potential yields and yield gaps of rainfed soybean in India using CROPGRO-Soybean model. Agric. For. Meteorol. 2008, 148, 1252-1265. [CrossRef]

46. Singh, P.; Aggarwal, P.K.; Bhatia, V.S.; Murty, M.V.R.; Pala, M.; Oweis, T.; Benli, B.; Rao, K.P.C.; Wani, S.P. Yield gap analysis: modelling of achievable yields at farm level. In Rainfed Agriculture: Unlocking the Potential. Comprehensive Assessment of Water Management in Agriculture Series 7; CABI Publishing: Wallingford, Oxfordshire, UK, 2009; pp. 81-123, ISBN 978-1-84593-389-0.

47. Hijmans, R.J.; Forbes, G.A.; Walker, T.S. Estimating the global severity of potato late blight with GIS-linked disease forecast models. Plant Pathol. 2000, 49, 697-705. [CrossRef]

48. Hijmans, R.J. The effect of climate change on global potato production. Am. J. Potato Res. 2003, 80, $271-279$. [CrossRef]

49. Hijmans, R.J.; Condori, B.; Carrillo, R.; Kropff, M.J. A quantitative and constraint-specific method to assess the potential impact of new agricultural technology: The case of frost resistant potato for the Altiplano (Peru and Bolivia). Agric. Syst. 2003, 76, 895-911. [CrossRef]

50. Hijmans, R.J.; Jacobs, M.; Bamberg, J.B.; Spooner, D.M. Frost tolerance in wild potato species: Assessing the predictivity of taxonomic, geographic, and ecological factors. Euphytica 2003, 130, 47-59. [CrossRef]

51. Andrade-Piedra, J.L.; Forbes, G.; Shtienberg, D.; Grünwald, N.J.; Chacón, M.G.; Taipe, M.V.; Hijmans, R.J.; Fry, W.E. Qualification of a Plant Disease Simulation Model: Performance of the LATEBLIGHT Model Across a Broad Range of Environments. Phytopathology 2005, 95, 1412-1422. [CrossRef]

52. Andrade-Piedra, J.L.; Hijmans, R.J.; Forbes, G.; Fry, W.E.; Nelson, R.J. Simulation of Potato Late Blight in the Andes. I: Modification and Parameterization of the LATEBLIGHT Model. Phytopathology 2005, 95, 1191-1199. [CrossRef]

53. Andrade-Piedra, J.L.; Hijmans, R.J.; Juárez, H.S.; Forbes, G.; Shtienberg, D.; Fry, W.E. Simulation of Potato Late Blight in the Andes. II: Validation of the LATEBLIGHT Model. Phytopathology 2005, 95, 1200-1208. [CrossRef]

54. Condori, B.; Mamani, P.; Botello, R.; Patiño, F.; Devaux, A.; Ledent, J.F. Agrophysiological characterisation and parametrisation of Andean tubers: Potato (Solanum sp.), oca (Oxalis tuberosa), isaño (Tropaeolum tuberosum) and papalisa (Ullucus tuberosus). Eur. J. Agron. 2008, 28, 526-540. [CrossRef]

55. Forbes, G.A.; Fry, W.E.; Andrade-Piedra, J.L.; Shtienberg, D.; Ciancio, A.; Mukerji, K.G. Simulation Models for Potato Late Blight Management and Ecology. In Integrated Management of Diseases Caused by Fungi, Phytoplasma and Bacteria; Ciancio, A., Mukerji, K.G., Eds.; Springer: Dordrecht, The Netherlands, 2008; pp. 161-177, ISBN 978-1-4020-8571-0.

56. Condori, B.; Hijmans, R.J.; Quiroz, R.; Ledent, J.F. Quantifying the expression of potato genetic diversity in the high Andes through growth analysis and modeling. Field Crops Res. 2010, 119, 135-144. [CrossRef]

57. Bouman, B.A.M.; Kropff, M.; Tuong, T.; Wopereis, M.; Ten Berge, H.; van Laar, H. ORYZA2000: Modeling Lowland Rice; International Rice Research Institute (IRRI), Wageningen University and Research Centre: Los Baños, Philippines, 2001; ISBN 971-22-0171-6.

58. Denier Van Der Gon, H.; Kropff, M.J.; Van Breemen, N.; Wassmann, R.; Lantin, R.S.; Aduna, E.; Corton, T.M.; Van Laar, H.H. Optimizing grain yields reduces $\mathrm{CH} 4$ emissions from rice paddy fields. Proc. Natl. Acad. Sci. USA 2002, 99, 12021-12024. [CrossRef] [PubMed]

59. Kropff, M.J.; Cassman, K.G.; Peng, S.; van Laar, H.H. Yields at IRRI research farm are still close to the climatic potential level. Int. Rice Res. Notes 2003, 28, 19-21.

60. Akanvou, R.K. Quantitative understanding of the performance of upland rice-Cover legume cropping systems in West Africa. Ph.D. Thesis, Wageningen University, Wageningen, The Netherlands, 2001.

61. Haefele, S.M.; Wopereis, M.C.S.; Ndiaye, M.K.; Kropff, M.J. A framework to improve fertilizer recommendations for irrigated rice in West Africa. Agric. Syst. 2003, 76, 313-335. [CrossRef]

62. Akanvou, R.; Bastiaans, L.; Kropff, M.J.; Becker, M. Analysis of the productivity of upland rice and COVER crops in relay intercropping systems using a mechanistic competition model. Agron. Afr. 2006, 18, 285-298. [CrossRef] 
63. Van Asten, P.J.A.; Wopereis, M.C.S.; Haefele, S.; Isselmou, M.O.; Kropff, M.J. Explaining yield gaps on farmer-identified degraded and non-degraded soils in a Sahelian irrigated rice scheme. NJAS Wagening. J. Life Sci. 2003, 50, 277-296. [CrossRef]

64. Hartkamp, A.D.; Hoogenboom, G.; Gilbert, R.A.; Benson, T.; Tarawali, S.A.; Gijsman, A.J.; Bowen, W.; White, J.W. Adaptation of the CROPGRO growth model to velvet bean (Mucuna pruriens) II. Cultivar evaluation and model testing. Field Crops Res. 2002, 78, 27-40. [CrossRef]

65. Jones, P.; Thornton, P. The potential impacts of climate change on maize production in Africa and Latin America in 2055. Glob. Environ. Chang. 2003, 13, 51-59. [CrossRef]

66. Jarvis, A.; Lane, A.; Hijmans, R.J. The effect of climate change on crop wild relatives. Agric. Ecosyst. Environ. 2008, 126, 13-23. [CrossRef]

67. Hunt, L.A.; Reynolds, M.P.; Sayre, K.D.; Rajaram, S.; White, J.W.; Yan, W. Crop modeling and the identification of stable coefficients that may reflect significant groups of genes. Agron. J. 2003, 95, 20-31. [CrossRef]

68. Hodson, D.P.; White, J.W. Use of spatial analyses for global characterization of wheat-based production systems. J. Agric. Sci. 2007, 145, 115. [CrossRef]

69. Erenstein, O.; Thorpe, W.; Singh, J.; Varma, A. Crop-Livestock Interactions and Livelihoods in The Trans-Gangetic Plains, India; CIMMYT: Mexico City, Mexico, 2007.

70. Singh, J.; Erenstein, O.; Thorpe, W.; Varma, A. Crop-Livestock Interactions and Livelihoods in the Gangetic Plains of Uttar Pradesh, India; ILRI Research Report 11; ILRI: Nairobi, Kenya, 2007; ISBN 9291462209.

71. Koo, J.; Bostick, W.M.; Naab, J.B.; Jones, J.W.; Graham, W.D.; Gijsman, A.J. Estimating soil carbon in agricultural systems using ensemble Kalman filter and DSSAT-CENTURY. Trans. ASABE 2007, 50, 1851-1865. [CrossRef]

72. Nelson, G.C.; Rosegrant, M.W.; Koo, J.; Robertson, R.; Sulser, T.; Zhu, T.; Ringler, C.; Msangi, S.; Palazzo, A.; Batka, M.; et al. Climate Change and Agriculture Impacts and costs of adaptation. Food Policy 2009, 307-324. [CrossRef]

73. Jarvis, A.; Ramirez-Villegas, J.; Campo, B.V.H.; Navarro-Racines, C. Is Cassava the Answer to African Climate Change Adaptation? Trop. Plant Biol. 2012, 5, 9-29. [CrossRef]

74. Ramirez-Villegas, J.; Jarvis, A.; Läderach, P. Empirical approaches for assessing impacts of climate change on agriculture: The EcoCrop model and a case study with grain sorghum. Agric. For. Meteorol. 2013, 170, 67-78. [CrossRef]

75. Ramirez-Villegas, J.; Watson, J.; Challinor, A.J. Identifying traits for genotypic adaptation using crop models. J. Exp. Bot. 2015, 66, 3451-3462. [CrossRef]

76. Cammarano, D.; Rötter, R.P.; Asseng, S.; Ewert, F.; Wallach, D.; Martre, P.; Hatfield, J.L.; Jones, J.W.; Rosenzweig, C.; Ruane, A.C.; et al. Uncertainty of wheat water use: Simulated patterns and sensitivity to temperature and $\mathrm{CO}_{2}$. Field Crops Res. 2016, 198, 80-92. [CrossRef]

77. Eitzinger, A.; Läderach, P.; Rodriguez, B.; Fisher, M.; Beebe, S.; Sonder, K.; Schmidt, A. Assessing high-impact spots of climate change: Spatial yield simulations with Decision Support System for Agrotechnology Transfer (DSSAT) model. Mitig. Adapt. Strateg. Glob. Chang. 2017, 22, 743-760. [CrossRef]

78. Durand, J.-L.; Delusca, K.; Boote, K.; Lizaso, J.; Manderscheid, R.; Weigel, H.J.; Ruane, A.C.; Rosenzweig, C.; Jones, J.; Ahuja, L.; et al. How accurately do maize crop models simulate the interactions of atmospheric CO2 concentration levels with limited water supply on water use and yield? Eur. J. Agron. 2017. [CrossRef]

79. Ramirez-Villegas, J.; Koehler, A.K.; Challinor, A.J. Assessing uncertainty and complexity in regional-scale crop model simulations. Eur. J. Agron. 2017, 88, 84-95. [CrossRef]

80. Piikki, K.; Winowiecki, L.; Vågen, T.G.; Ramirez-Villegas, J.; Söderström, M. Improvement of spatial modelling of crop suitability using a new digital soil map of Tanzania. S. Afr. J. Plant Soil 2017, 34, 243-254. [CrossRef]

81. Fodor, N.; Challinor, A.; Droutsas, I.; Ramirez-Villegas, J.; Zabel, F.; Koehler, A.-K.; Foyer, C.H. Integrating Plant Science and Crop Modeling: Assessment of the Impact of Climate Change on Soybean and Maize Production. Plant Cell Physiol. 2017, 58, 1833-1847. [CrossRef]

82. Heinemann, A.B.; Ramirez-Villegas, J.; Stone, L.F.; Didonet, A.D. Climate change determined drought stress profiles in rainfed common bean production systems in Brazil. Agric. For. Meteorol. 2017, 246, 64-77. [CrossRef] 
83. Ramirez-Villegas, J.; Heinemann, A.B.; Pereira de Castro, A.; Breseghello, F.; Navarro-Racines, C.; Li, T.; Rebolledo, M.C.; Challinor, A.J. Breeding implications of drought stress under future climate for upland rice in Brazil. Glob. Chang. Biol. 2018, 24, 2035-2050. [CrossRef] [PubMed]

84. Cammarano, D.; Rivington, M.; Matthews, K.B.; Miller, D.G.; Bellocchi, G. Implications of climate model biases and downscaling on crop model simulated climate change impacts. Eur. J. Agron. 2017, 88, 63-75. [CrossRef]

85. Challinor, A.J.; Müller, C.; Asseng, S.; Deva, C.; Nicklin, K.J.; Wallach, D.; Vanuytrecht, E.; Whitfield, S.; Ramirez-Villegas, J.; Koehler, A.-K. Improving the use of crop models for risk assessment and climate change adaptation. Agric. Syst. 2018, 159, 296-306. [CrossRef]

86. Nelson, G.C.; Rosegrant, M.W.; Palazzo, A.; Gray, I.; Ingersoll, C.; Robertson, R.D.; Tokgoz, S.; Zhu, T.; Sulser, T.B.; Ringler, C.; et al. Food Security, Farming, and Climate Change to 2050: Scenarios, Results, Policy Options; International Food Policy Research Institute (IFPRI): Washington, DC, USA, 2010; ISBN 978-0-89629-186-7.

87. Wiebelt, M.; Breisinger, C.; Ecker, O.; Al-Riffai, P.; Robertson, R.; Thiele, R. Compounding food and income insecurity in Yemen: Challenges from climate change. Food Policy 2013, 43, 77-89. [CrossRef]

88. Robertson, R.; Nelson, G.; Thomas, T.; Rosegrant, M. Incorporating process-based crop simulation models into global economic analyses. Am. J. Agric. Econ. 2013, 95, 228-235. [CrossRef]

89. Negassa, A.; Shiferaw, B.; Koo, J.; Sonder, K.; Smale, M.; Braun, H.J.; Gbegbelegbe, S.; Guo, Z.; Hodson, D.P.; Wood, S.; et al. The Potential for Wheat Production in Africa: Analysis of Biophysical Suitability and Economic Profitability; CIMMYT: Mexico City, Mexico, 2013; ISBN 9786078263288.

90. Nelson, G.C.; Valin, H.; Sands, R.D.; Havlík, P.; Ahammad, H.; Deryng, D.; Elliott, J.; Fujimori, S.; Hasegawa, T.; Heyhoe, E.; et al. Climate change effects on agriculture: Economic responses to biophysical shocks. Proc. Natl. Acad. Sci. USA 2014, 111, 3274-3279. [CrossRef]

91. Nelson, G.C.; van der Mensbrugghe, D.; Ahammad, H.; Blanc, E.; Calvin, K.; Hasegawa, T.; Havlik, P.; Heyhoe, E.; Kyle, P.; Lotze-Campen, H.; et al. Agriculture and climate change in global scenarios: Why don't the models agree. Agric. Econ. 2014, 45, 85-101. [CrossRef]

92. Rosegrant, M.W.; Koo, J.; Cenacchi, N.; Ringler, C.; Robertson, R.; Fisher, M.; Cox, C.; Garrett, K.; Perez, N.D.; Sabbagh, P. Food Security in a World of Natural Resource Scarcity: The Role of Agricultural Technologies; International Food Policy Research Institute (IFPRI): Washington, DC, USA, 2014; Volume 79, ISBN 9780896298477.

93. Müller, C.; Robertson, R.D. Projecting future crop productivity for global economic modeling. Agric. Econ. 2014, 45, 37-50. [CrossRef]

94. Robinson, S.; Mason-D'croz, D.; Islam, S.; Cenacchi, N.; Creamer, B.; Gueneau, A.; Hareau, G.; Kleinwechter, U.; Mottaleb, K.; Nedumaran, S.; et al. Climate Change Adaptation in Agriculture: Ex Ante Analysis of Promising and Alternative Crop Technologies Using DSSAT and IMPACT; IFPRI Discussion Paper 01469; International Food Policy Research Institute (IFPRI): Washington, DC, USA, 2015.

95. Robinson, S.; Mason-D'Croz, D.; Islam, S.; Sulser, T.B.; Robertson, R.; Zhu, T.; Gueneau, A.; Pitois, G.; Rosegrant, M. The International Model for Policy Analysis of Agricultural Commodities and Trade (IMPACT): Model Description for Version 3; IFPRI Discussion Paper 1483; International Food Policy Research Institute (IFPRI): Washington, DC, USA, 2015.

96. Islam, S.; Cenacchi, N.; Sulser, T.B.; Gbegbelegbe, S.; Hareau, G.; Kleinwechter, U.; Mason-D'Croz, D.; Nedumaran, S.; Robertson, R.; Robinson, S.; et al. Structural approaches to modeling the impact of climate change and adaptation technologies on crop yields and food security. Glob. Food Secur. 2016, 10, 63-70. [CrossRef]

97. Zougmoré, R.; Partey, S.; Ouédraogo, M.; Omitoyin, B.; Thomas, T.; Ayantunde, A.; Ericksen, P.; Said, M.; Jalloh, A. Toward climate-smart agriculture in West Africa: A review of climate change impacts, adaptation strategies and policy developments for the livestock, fishery and crop production sectors. Agric. Food Secur. 2016, 5, 26. [CrossRef]

98. Rosegrant, M.W.; Sulser, T.B.; Mason-D'croz, D.; Cenacchi, N.; Nin-Pratt, A.; Dunston, S.; Zhu, T.; Ringler, C.; Wiebe, K.D.; Robinson, S.; et al. Quantitative Foresight Modeling to Inform the CGIAR Research Portfolio; Project Report for USAID; International Food Policy Research Institute (IFPRI): Washington, DC, USA, 2017. 
99. Rosenzweig, C.; Ruane, A.C.; Antle, J.; Elliott, J.; Ashfaq, M.; Chatta, A.A.; Ewert, F.; Folberth, C.; Hathie, I.; Havlik, P.; et al. Coordinating AgMIP data and models across global and regional scales for $1.5^{\circ} \mathrm{C}$ and $2.0^{\circ} \mathrm{C}$ assessments. Philos. Trans. A Math. Phys. Eng. Sci. 2018, 376, 20160455. [CrossRef]

100. Li, T.; Raman, A.K.; Marcaida, M.; Kumar, A.; Angeles, O.; Radanielson, A.M. Simulation of genotype performances across a larger number of environments for rice breeding using ORYZA2000. Field Crops Res. 2013, 149, 312-321. [CrossRef]

101. Li, T.; Angeles, O.; Radanielson, A.; Marcaida, M.; Manalo, E. Drought stress impacts of climate change on rainfed rice in South Asia. Clim. Chang. 2015, 133, 709-720. [CrossRef]

102. Li, T.; Hasegawa, T.; Yin, X.; Zhu, Y.; Boote, K.; Adam, M.; Bregaglio, S.; Buis, S.; Confalonieri, R.; Fumoto, T.; et al. Uncertainties in predicting rice yield by current crop models under a wide range of climatic conditions. Glob. Chang. Biol. 2015, 21, 1328-1341. [CrossRef]

103. Silva, J.V.; Reidsma, P.; Laborte, A.G.; van Ittersum, M.K. Explaining rice yields and yield gaps in Central Luzon, Philippines: An application of stochastic frontier analysis and crop modelling. Eur. J. Agron. 2017, 82, 223-241. [CrossRef]

104. Dingkuhn, M.; Pasco, R.; Pasuquin, J.M.; Damo, J.; Soulié, J.-C.; Raboin, L.-M.; Dusserre, J.; Sow, A.; Manneh, B.; Shrestha, S.; et al. Crop-model assisted phenomics and genome-wide association study for climate adaptation of indica rice. 1. Phenology. J. Exp. Bot. 2017, 68, 4369-4388. [CrossRef]

105. Dingkuhn, M.; Pasco, R.; Pasuquin, J.M.; Damo, J.; Soulié, J.-C.; Raboin, L.-M.; Dusserre, J.; Sow, A.; Manneh, B.; Shrestha, S.; et al. Crop-model assisted phenomics and genome-wide association study for climate adaptation of indica rice. 2. Thermal stress and spikelet sterility. J. Exp. Bot. 2017, 68, 4389-4406. [CrossRef] [PubMed]

106. Mottaleb, K.A.; Rejesus, R.M.; Murty, M.; Mohanty, S.; Li, T. Benefits of the development and dissemination of climate-smart rice: ex ante impact assessment of drought-tolerant rice in South Asia. Mitig. Adapt. Strateg. Glob. Chang. 2017, 22, 879-901. [CrossRef]

107. Li, T.; Angeles, O.; Marcaida, M.; Manalo, E.; Manalili, M.P.; Radanielson, A.; Mohanty, S. From ORYZA2000 to ORYZA (v3): An improved simulation model for rice in drought and nitrogen-deficient environments. Agric. For. Meteorol. 2017, 237-238, 246-256. [CrossRef] [PubMed]

108. Savary, S.; Nelson, A.D.; Djurle, A.; Esker, P.D.; Sparks, A.; Amorim, L.; Bergamin Filho, A.; Caffi, T.; Castilla, N.; Garrett, K.; et al. Concepts, approaches, and avenues for modelling crop health and crop losses. Eur. J. Agron. 2018. [CrossRef]

109. Ngwira, A.R.; Aune, J.B.; Thierfelder, C. DSSAT modelling of conservation agriculture maize response to climate change in Malawi. Soil Tillage Res. 2014, 143. [CrossRef]

110. Chung, U.; Gbegbelegbe, S.; Shiferaw, B.; Robertson, R.; Yun, J.I.; Tesfaye, K.; Hoogenboom, G.; Sonder, K. Modeling the effect of a heat wave on maize production in the USA and its implications on food security in the developing world. Weather Clim. Extrem. 2014, 5, 67-77. [CrossRef]

111. Gbegbelegbe, S.; Chung, U.; Shiferaw, B.; Msangi, S.; Tesfaye, K. Quantifying the impact of weather extremes on global food security: A spatial bio-economic approach. Weather Clim. Extrem. 2014, 4, 96-108. [CrossRef]

112. Tesfaye, K.; Gbegbelegbe, S.; Cairns, J.E.; Shiferaw, B.; Prasanna, B.M.; Sonder, K.; Boote, K.; Makumbi, D.; Robertson, R. Maize systems under climate change in sub-Saharan Africa. Int. J. Clim. Chang. Strateg. Manag. 2015, 7, 247-271. [CrossRef]

113. Tesfaye, K.; Sonder, K.; Cairns, J.; Magorokosho, C.; Tarekegn, A.; Kassie, G.T.; Getaneh, F.; Abdoulaye, T.; Abate, T.; Erenstein, O. Targeting drought-tolerant maize varieties in Southern Africa: A geospatial crop modeling approach using big data. Int. Food Agribus. Manag. Rev. 2016, 19, 75-92.

114. Corbeels, M.; Chirat, G.; Messad, S.; Thierfelder, C. Performance and sensitivity of the DSSAT crop growth model in simulating maize yield under conservation agriculture. Eur. J. Agron. 2016, 76, 41-53. [CrossRef]

115. Rutkoski, J.; Poland, J.; Mondal, S.; Autrique, E.; Pérez, L.G.; Crossa, J.; Reynolds, M.; Singh, R. Canopy Temperature and Vegetation Indices from High-Throughput Phenotyping Improve Accuracy of Pedigree and Genomic Selection for Grain Yield in Wheat. G3 Genes Genomes Genet. 2016, 6, 2799-2808. [CrossRef] [PubMed]

116. Gaydon, D.S.; Balwinder-Singh; Wang, E.; Poulton, P.L.; Ahmad, B.; Ahmed, F.; Akhter, S.; Ali, I.; Amarasingha, R.; Chaki, A.K.; et al. Evaluation of the APSIM model in cropping systems of Asia. Field Crops Res. 2017, 204, 52-75. [CrossRef] 
117. Alderman, P.D.; Stanfill, B. Quantifying model-structure- and parameter-driven uncertainties in spring wheat phenology prediction with Bayesian analysis. Eur. J. Agron. 2017, 88, 1-9. [CrossRef]

118. Maiorano, A.; Asseng, S.; Müller, C.; Rötter, R.P.; Ruane, A.C.; Semenov, M.A.; Wallach, D.; Wang, E.; Alderman, P.D.; Kassie, B.T.; et al. Crop model improvement reduces the uncertainty of the response to temperature of multi-model ensembles. Field Crops Res. 2017, 202, 5-20. [CrossRef]

119. Tesfaye, K.; Zaidi, P.H.; Gbegbelegbe, S.; Boeber, C.; Rahut, D.B.; Getaneh, F.; Seetharam, K.; Erenstein, O.; Stirling, C. Climate change impacts and potential benefits of heat-tolerant maize in South Asia. Theor. Appl. Climatol. 2017, 130, 959-970. [CrossRef]

120. Tesfaye, K.; Aggarwal, P.; Mequanint, F.; Shirsath, P.; Stirling, C.; Khatri-Chhetri, A.; Rahut, D. Climate Variability and Change in Bihar, India: Challenges and Opportunities for Sustainable Crop Production. Sustainability 2017, 9, 1998. [CrossRef]

121. Tonnang, H.E.Z.; Hervé, B.D.B.; Biber-Freudenberger, L.; Salifu, D.; Subramanian, S.; Ngowi, V.B.; Guimapi, R.Y.A.; Anani, B.; Kakmeni, F.M.M.; Affognon, H.; et al. Advances in crop insect modelling methods-Towards a whole system approach. Ecol. Model. 2017, 354, 88-103. [CrossRef]

122. Jain, M.; Singh, B.; Srivastava, A.A.K.; Malik, R.K.; McDonald, A.J.; Lobell, D.B. Using satellite data to identify the causes of and potential solutions for yield gaps in India's Wheat Belt. Environ. Res. Lett. 2017, 12, 094011. [CrossRef]

123. Sukumaran, S.; Crossa, J.; Jarquín, D.; Reynolds, M. Pedigree-based prediction models with genotype $\times$ environment interaction in multienvironment trials of CIMMYT wheat. Crop Sci. 2017, 57, 1865-1880. [CrossRef]

124. Sukumaran, S.; Crossa, J.; Jarquin, D.; Lopes, M.; Reynolds, M.P. Genomic Prediction with Pedigree and Genotype $\times$ Environment Interaction in Spring Wheat Grown in South and West Asia, North Africa, and Mexico. G3 Genes Genomes Genet. 2017, 7, 481-495. [CrossRef]

125. Juliana, P.; Singh, R.P.; Singh, P.K.; Crossa, J.; Huerta-Espino, J.; Lan, C.; Bhavani, S.; Rutkoski, J.E.; Poland, J.A.; Bergstrom, G.C.; et al. Genomic and pedigree-based prediction for leaf, stem, and stripe rust resistance in wheat. Theor. Appl. Genet. 2017, 130, 1415-1430. [CrossRef]

126. Juliana, P.; Singh, R.P.; Singh, P.K.; Crossa, J.; Rutkoski, J.E.; Poland, J.A.; Bergstrom, G.C.; Sorrells, M.E. Comparison of Models and Whole-Genome Profiling Approaches for Genomic-Enabled Prediction of Septoria Tritici Blotch, Stagonospora Nodorum Blotch, and Tan Spot Resistance in Wheat. Plant Genome 2017, 10, 1-16. [CrossRef] [PubMed]

127. Pérez-Rodríguez, P.; Crossa, J.; Rutkoski, J.; Poland, J.; Singh, R.; Legarra, A.; Autrique, E.; de los Campos, G.; Burgueño, J.; Dreisigacker, S. Single-Step Genomic and Pedigree Genotype $\times$ Environment Interaction Models for Predicting Wheat Lines in International Environments. Plant Genome 2017, 10, 1-15. [CrossRef] [PubMed]

128. Montesinos-López, O.A.; Montesinos-López, A.; Crossa, J.; los Campos, G.; Alvarado, G.; Suchismita, M.; Rutkoski, J.; González-Pérez, L.; Burgueño, J. Predicting grain yield using canopy hyperspectral reflectance in wheat breeding data. Plant Methods 2017, 13, 1-23. [CrossRef]

129. Montesinos-López, O.A.; Montesinos-López, A.; Crossa, J.; Toledo, F.H.; Montesinos-López, J.C.; Singh, P.; Juliana, P.; Salinas-Ruiz, J. A Bayesian Poisson-lognormal Model for Count Data for Multiple-Trait Multiple-Environment Genomic-Enabled Prediction. G3 Genes Genomes Genet. 2017, 7, 1595-1606. [CrossRef] [PubMed]

130. Montesinos-López, A.; Montesinos-López, O.A.; Cuevas, J.; Mata-López, W.A.; Burgueño, J.; Mondal, S.; Huerta, J.; Singh, R.; Autrique, E.; González-Pérez, L.; et al. Genomic Bayesian functional regression models with interactions for predicting wheat grain yield using hyper-spectral image data. Plant Methods 2017, 13, 1-29. [CrossRef]

131. Sun, J.; Rutkoski, J.E.; Poland, J.A.; Crossa, J.; Jannink, J.-L.; Sorrells, M.E. Multitrait, Random Regression, or Simple Repeatability Model in High-Throughput Phenotyping Data Improve Genomic Prediction for Wheat Grain Yield. Plant Genome 2017, 10, 1-12. [CrossRef] [PubMed]

132. Jarquín, D.; Lemes da Silva, C.; Gaynor, R.C.; Poland, J.; Fritz, A.; Howard, R.; Battenfield, S.; Crossa, J. Increasing Genomic-Enabled Prediction Accuracy by Modeling Genotype $\times$ Environment Interactions in Kansas Wheat. Plant Genome 2017, 10. [CrossRef]

133. Dunckel, S.; Crossa, J.; Wu, S.; Bonnett, D.; Poland, J. Genomic selection for increased yield in synthetic-derived wheat. Crop Sci. 2017, 57, 713-725. [CrossRef] 
134. Cuevas, J.; Crossa, J.; Soberanis, V.; Perez-Elizalde, S.; Perez-Rodriguez, P.; de Los Campos, G.; Montesinos-Lopez, O.A.; Burgueño, J. Genomic Prediction of Genotype x Environment Interaction Kernel Regression Models. Plant Genome 2017, 9, 1-20. [CrossRef]

135. Crossa, J.; Pérez-Rodríguez, P.; Cuevas, J.; Montesinos-López, O.; Jarquín, D.; de los Campos, G.; Burgueño, J.; González-Camacho, J.M.; Pérez-Elizalde, S.; Beyene, Y.; et al. Genomic Selection in Plant Breeding: Methods, Models, and Perspectives. Trends Plant Sci. 2017, 22, 961-975. [CrossRef]

136. Crespo-Herrera, L.A.; Crossa, J.; Huerta-Espino, J.; Autrique, E.; Mondal, S.; Velu, G.; Vargas, M.; Braun, H.J.; Singh, R.P. Genetic yield gains in CIMMYT'S international elite spring wheat yield trials by modeling the genotype $\times$ environment interaction. Crop Sci. 2017, 57, 789-801. [CrossRef]

137. Corbeels, M.; Berre, D.; Rusinamhodzi, L.; Lopez-Ridaura, S. Can we use crop modelling for identifying climate change adaptation options? Agric. For. Meteorol. 2018, 256-257, 46-52. [CrossRef]

138. Tesfaye, K.; Kruseman, G.; Cairns, J.E.; Mainassara Zaman-Allah, D.W.; Zaidi, P.H.; Boote, K.J.; Rahut, D.; Erenstein, O. Potential benefits of drought and heat tolerance for adapting maize to climate change in tropical environments. Clim. Risk Manag. 2018, 19, 106-119. [CrossRef]

139. Montesinos-López, O.A.; Luna-Vazquez, F.J.; Montesinos- López, A.; Juliana, P.; Singh, R.; Crossa, J. An R Package for Multi-Trait and Multi-Environment Data with the Item Based Collaborative Filtering Algorithm. Plant Genome 2018, 11, 1-16. [CrossRef]

140. Montesinos-López, O.A.; Montesinos-López, A.; Crossa, J.; Montesinos-López, J.C.; Mota-Sanchez, D.; Estrada-González, F.; Gillberg, J.; Singh, R.; Mondal, S.; Juliana, P. Prediction of Multiple-Trait and Multiple-Environment Genomic Data Using Recommender Systems. G3 Genes Genomes Genet. 2018, 8, 131-147. [CrossRef] [PubMed]

141. Cuevas, J.; Granato, I.; Fritsche-Neto, R.; Montesinos-Lopez, O.A.; Burgueño, J.; Bandeira, E.; Sousa, M.; Crossa, J. Genomic-Enabled Prediction Kernel Models with Random Intercepts for Multi-environment Trials. G3 Genes Genomes Genet. 2018, 8, 1347-1365. [CrossRef]

142. Sukumaran, S.; Jarquin, D.; Crossa, J.; Reynolds, M. Genomic-enabled Prediction Accuracies Increased by Modeling Genotype $\times$ Environment Interaction in Durum Wheat. Plant Genome 2018, 11, 1-11. [CrossRef]

143. Vadez, V.; Soltani, A.; Sinclair, T.R. Modelling possible benefits of root related traits to enhance terminal drought adaptation of chickpea. Field Crops Res. 2012, 137, 108-115. [CrossRef]

144. Singh, P.; Boote, K.J.; Kumar, U.; Srinivas, K.; Nigam, S.N.; Jones, J.W. Evaluation of Genetic Traits for Improving Productivity and Adaptation of Groundnut to Climate Change in India. J. Agron. Crop Sci. 2012, 198, 399-413. [CrossRef]

145. Vadez, V.; Soltani, A.; Sinclair, T.R. Crop simulation analysis of phenological adaptation of chickpea to different latitudes of India. Field Crops Res. 2013, 146, 1-9. [CrossRef]

146. Vadez, V.; Kholova, J. Coping with drought: Resilience versus risk. Targeting the most suitable $G^{*} E^{*} M$ options by crop simulation modeling. Sci. Chang. Planet. Secher. 2013, 24, 274-281. [CrossRef]

147. Craufurd, P.Q.; Vadez, V.; Jagadish, S.V.K.; Prasad, P.V.V.; Zaman-Allah, M. Crop science experiments designed to inform crop modeling. Agric. For. Meteorol. 2013, 170, 8-18. [CrossRef]

148. Nedumaran, S.; Shiferaw, B.; Bantilan, M.C.S.; Palanisami, K.; Wani, S.P. Bioeconomic modeling of farm household decisions for ex-ante impact assessment of integrated watershed development programs in semi-arid India. Environ. Dev. Sustain. 2014, 16, 257-286. [CrossRef]

149. Kholová, J.; McLean, G.; Vadez, V.; Craufurd, P.; Hammer, G.L. Drought stress characterization of post-rainy season (rabi) sorghum in India. Field Crops Res. 2013, 141, 38-46. [CrossRef]

150. Homann-Kee Tui, S.; Blümmel, M.; Valbuena, D.; Chirima, A.; Masikati, P.; van Rooyen, A.F.; Kassie, G.T. Assessing the potential of dual-purpose maize in southern Africa: A multi-level approach. Field Crops Res. 2013, 153, 37-51. [CrossRef]

151. Kholová, J.; Murugesan, T.; Kaliamoorthy, S.; Malayee, S.; Baddam, R.; Hammer, G.L.; McLean, G.; Deshpande, S.; Hash, C.T.; Craufurd, P.Q.; et al. Modelling the effect of plant water use traits on yield and stay-green expression in sorghum. Funct. Plant Biol. 2014, 41, 1019-1034. [CrossRef]

152. Sinclair, T.R.; Marrou, H.; Soltani, A.; Vadez, V.; Chandolu, K.C. Soybean production potential in Africa. Glob. Food Secur. 2014, 3, 31-40. [CrossRef]

153. Singh, P.; Nedumaran, S.; Boote, K.J.; Gaur, P.M.; Srinivas, K.; Bantilan, M.C.S. Climate change impacts and potential benefits of drought and heat tolerance in chickpea in South Asia and East Africa. Eur. J. Agron. 2014, 52, 123-137. [CrossRef] 
154. Singh, P.; Nedumaran, S.; Traore, P.C.S.; Boote, K.J.; Rattunde, H.F.W.; Prasad, P.V.V.; Singh, N.P.; Srinivas, K.; Bantilan, M.C.S. Quantifying potential benefits of drought and heat tolerance in rainy season sorghum for adapting to climate change. Agric. For. Meteorol. 2014, 185, 37-48. [CrossRef]

155. Singh, P.; Nedumaran, S.; Ntare, B.R.; Boote, K.J.; Singh, N.P.; Srinivas, K.; Bantilan, M.C.S. Potential benefits of drought and heat tolerance in groundnut for adaptation to climate change in India and West Africa. Mitig. Adapt. Strateg. Glob. Chang. 2014, 19, 509-529. [CrossRef]

156. Singh, P.; Singh, N.P.; Boote, K.J.; Nedumaran, S.; Srinivas, K.; Bantilan, M.C.S. Management options to increase groundnut productivity under climate change at selected sites in India. J. Agrometeorol. 2014, 16, 152-159.

157. Soltani, A.; Hajjarpour, A.; Vadez, V. Analysis of chickpea yield gap and water-limited potential yield in Iran. Field Crops Res. 2016, 185, 21-30. [CrossRef]

158. Vadez, V.; Halilou, O.; Hissene, H.M.; Sibiry-Traore, P.; Sinclair, T.R.; Soltani, A. Mapping Water Stress Incidence and Intensity, Optimal Plant Populations, and Cultivar Duration for African Groundnut Productivity Enhancement. Front. Plant Sci. 2017, 8, 1-13. [CrossRef] [PubMed]

159. Traore, B.; Descheemaeker, K.; van Wijk, M.T.; Corbeels, M.; Supit, I.; Giller, K.E. Modelling cereal crops to assess future climate risk for family food self-sufficiency in southern Mali. Field Crops Res. 2017, 201, 133-145. [CrossRef]

160. Singh, P.; Boote, K.J.; Kadiyala, M.D.M.; Nedumaran, S.; Gupta, S.K.; Srinivas, K.; Bantilan, M.C.S. An assessment of yield gains under climate change due to genetic modification of pearl millet. Sci. Total Environ. 2017, 601-602, 1226-1237. [CrossRef] [PubMed]

161. Mohammed, A.; Tana, T.; Singh, P.; Molla, A.; Seid, A. Identifying best crop management practices for chickpea (Cicer arietinum L.) in Northeastern Ethiopia under climate change condition. Agric. Water Manag. 2017, 194, 68-77. [CrossRef]

162. Mohammed, A.; Tana, T.; Singh, P.; Korecha, D.; Molla, A. Management options for rainfed chickpea (Cicer arietinum L.) in northeast Ethiopia under climate change condition. Clim. Risk Manag. 2017, 16, 222-233. [CrossRef]

163. Boote, K.J.; Prasad, V.; Allen, L.H.; Singh, P.; Jones, J.W. Modeling sensitivity of grain yield to elevated temperature in the DSSAT crop models for peanut, soybean, dry bean, chickpea, sorghum, and millet. Eur. J. Agron. 2017. [CrossRef]

164. Nelson, W.C.D.; Hoffmann, M.P.; Vadez, V.; Roetter, R.P.; Whitbread, A.M. Testing pearl millet and cowpea intercropping systems under high temperatures. Field Crops Res. 2018, 217, 150-166. [CrossRef]

165. Faye, B.; Webber, H.; Naab, J.B.; MacCarthy, D.S.; Adam, M.; Ewert, F.; Lamers, J.P.A.; Schleussner, C.-F.; Ruane, A.; Gessner, U.; et al. Impacts of 1.5 versus $2.0^{\circ} \mathrm{C}$ on cereal yields in the West African Sudan Savanna. Environ. Res. Lett. 2018, 13, 034014. [CrossRef]

166. Adam, M.; Dzotsi, K.A.; Hoogenboom, G.; Traoré, P.C.S.; Porter, C.H.; Rattunde, H.F.W.; Nebie, B.; Leiser, W.L.; Weltzien, E.; Jones, J.W. Modelling varietal differences in response to phosphorus in West African sorghum. Eur. J. Agron. 2018. [CrossRef]

167. Kroschel, J.; Sporleder, M.; Tonnang, H.E.Z.; Juarez, H.; Carhuapoma, P.; Gonzales, J.C.; Simon, R. Predicting climate-change-caused changes in global temperature on potato tuber moth Phthorimaea operculella (Zeller) distribution and abundance using phenology modeling and GIS mapping. Agric. For. Meteorol. 2013, 170, 228-241. [CrossRef]

168. Sporleder, M.; Tonnang, H.E.Z.; Carhuapoma, P.; Gonzales, J.C.; Juarez, H.; Kroschel, J. Insect Life Cycle Modelling (ILCYM) software-A new tool for regional and global insect pest risk assessments under current and future climate change scenarios. In Potential Invasive Pests of Agricultural Crops; Peña, J.E., Ed.; CABI Publishing: Wallingford, UK, 2013; pp. 412-427, ISBN 978-1-84593-829-1.

169. Condori, B.; Hijmans, R.J.; Ledent, J.F.; Quiroz, R. Managing potato biodiversity to cope with frost risk in the high Andes: A modeling perspective. PLoS ONE 2014. [CrossRef] [PubMed]

170. Carli, C.; Yuldashev, F.; Khalikov, D.; Condori, B.; Mares, V.; Monneveux, P. Effect of different irrigation regimes on yield, water use efficiency and quality of potato (Solanum tuberosum L.) in the lowlands of Tashkent, Uzbekistan: A field and modeling perspective. Field Crops Res. 2014, 163, 90-99. [CrossRef]

171. Kleinwechter, U.; Gastelo, M.; Ritchie, J.; Nelson, G.; Asseng, S. Simulating cultivar variations in potato yields for contrasting environments. Agric. Syst. 2016, 145, 51-63. [CrossRef] 
172. Sporleder, M.; Schaub, B.; Aldana, G.; Kroschel, J. Temperature-dependent phenology and growth potential of the Andean potato tuber moth, Symmetrischema tangolias (Gyen) (Lep., Gelechiidae). J. Appl. Entomol. 2017, 141, 202-218. [CrossRef]

173. Fleisher, D.H.; Condori, B.; Quiroz, R.; Alva, A.; Asseng, S.; Barreda, C.; Bindi, M.; Boote, K.J.; Ferrise, R.; Franke, A.C.; et al. A potato model intercomparison across varying climates and productivity levels. Glob. Chang. Biol. 2017, 23, 1258-1281. [CrossRef]

174. Raymundo, R.; Asseng, S.; Robertson, R.; Petsakos, A.; Hoogenboom, G.; Quiroz, R.; Hareau, G.; Wolf, J. Climate change impact on global potato production. Eur. J. Agron. 2017, in press. [CrossRef]

175. Raymundo, R.; Asseng, S.; Prassad, R.; Kleinwechter, U.; Concha, J.; Condori, B.; Bowen, W.; Wolf, J.; Olesen, J.E.; Dong, Q.; et al. Performance of the SUBSTOR-potato model across contrasting growing conditions. Field Crops Res. 2017, 202, 57-76. [CrossRef]

176. Quiroz, R.; Loayza, H.; Barreda, C.; Gavilán, C.; Posadas, A.; Ramírez, D.A. Linking process-based potato models with light reflectance data: Does model complexity enhance yield prediction accuracy? Eur. J. Agron. 2017, 82, 104-112. [CrossRef]

177. Ramírez, D.A.; Gavilán, C.; Barreda, C.; Condori, B.; Rossel, G.; Mwanga, R.O.M.; Andrade, M.; Monneveux, P.; Anglin, N.L.; Ellis, D.; et al. Characterizing the diversity of sweetpotato through growth parameters and leaf traits: Precocity and light use efficiency as important ordination factors. S. Afr. J. Bot. 2017, 113, 192-199. [CrossRef]

178. Mujica, N.; Sporleder, M.; Carhuapoma, P.; Kroschel, J. A Temperature-Dependent Phenology Model for Liriomyza huidobrensis (Diptera: Agromyzidae). J. Econ. Entomol. 2017, 1-12. [CrossRef] [PubMed]

179. Scott, G.J.; Kleinwechter, U. Future Scenarios for Potato Demand, Supply and Trade in South America to 2030. Potato Res. 2017, 60, 23-45. [CrossRef]

180. Petsakos, A.; Hareau, G.; Kleinwechter, U.; Wiebe, K.; Sulser, T.B. Comparing modeling approaches for assessing priorities in international agricultural research. Res. Eval. 2018, 27, 145-156. [CrossRef]

181. Van Oort, P.A.J.; Saito, K.; Zwart, S.J.; Shrestha, S. A simple model for simulating heat induced sterility in rice as a function of flowering time and transpirational cooling. Field Crops Res. 2014, 156, 303-312. [CrossRef]

182. Van Oort, P.A.J.; De Vries, M.E.; Yoshida, H.; Saito, K. Improved climate risk simulations for rice in arid environments. PLoS ONE 2015, 10, e0118114. [CrossRef] [PubMed]

183. Van Oort, P.A.J.; Saito, K.; Tanaka, A.; Amovin-Assagba, E.; Van Bussel, L.G.J.; Van Wart, J.; De Groot, H.; Van Ittersum, M.K.; Cassman, K.G.; Wopereis, M.C.S. Assessment of rice self-sufficiency in 2025 in eight African countries. Glob. Food Secur. 2015, 5, 39-49. [CrossRef]

184. Dingkuhn, M.; Sow, A.; Manneh, B.; Radanielina, T.; Raboin, L.M.; Dusserre, J.; Ramantsoanirina, A.; Shrestha, S.; Ahmadi, N.; Courtois, B. Field phenomics for response of a rice diversity panel to ten environments in Senegal and Madagascar. 1. Plant phenological traits. Field Crops Res. 2015, 183, 342-355. [CrossRef]

185. van Oort, P.A.J.; Balde, A.; Diagne, M.; Dingkuhn, M.; Manneh, B.; Muller, B.; Sow, A.; Stuerz, S. Intensification of an irrigated rice system in Senegal: Crop rotations, climate risks, sowing dates and varietal adaptation options. Eur. J. Agron. 2016, 80, 168-181. [CrossRef]

186. El-Namaky, R.; van Oort, P.A.J. Phenology, sterility and inheritance of two environment genic male sterile (EGMS) lines for hybrid rice. Rice 2017, 10, 31. [CrossRef]

187. van Oort, P.A.J.; Saito, K.; Dieng, I.; Grassini, P.; Cassman, K.G.; van Ittersum, M.K. Can yield gap analysis be used to inform R\&D prioritisation? Glob. Food Secur. 2017, 12, 109-118.

188. van Oort, P.A.J.; Zwart, S.J. Impacts of climate change on rice production in Africa and causes of simulated yield changes. Glob. Chang. Biol. 2018, 24, 1029-1045. [CrossRef] [PubMed]

189. van Oort, P.A.J. Mapping abiotic stresses for rice in Africa: Drought, cold, iron toxicity, salinity and sodicity. Field Crops Res. 2018, 219, 55-75. [CrossRef] [PubMed]

190. Duku, C.; Zwart, S.J.; Hein, L. Impacts of climate change on cropping patterns in a tropical, sub-humid watershed. PLoS ONE 2018, 13, e0192642. [CrossRef] [PubMed]

191. Luedeling, E.; Kindt, R.; Huth, N.I.; Koenig, K. Agroforestry systems in a changing climate—Challenges in projecting future performance. Curr. Opin. Environ. Sustain. 2014, 6, 1-7. [CrossRef]

192. Araya, A.; Hoogenboom, G.; Luedeling, E.; Hadgu, K.M.; Kisekka, I.; Martorano, L.G. Assessment of maize growth and yield using crop models under present and future climate in southwestern Ethiopia. Agric. For. Meteorol. 2015, 214-215, 252-265. [CrossRef] 
193. Luedeling, E.; Smethurst, P.J.; Baudron, F.; Bayala, J.; Huth, N.I.; van Noordwijk, M.; Ong, C.K.; Mulia, R.; Lusiana, B.; Muthuri, C.; et al. Field-scale modeling of tree-crop interactions: Challenges and development needs. Agric. Syst. 2016, 142, 51-69. [CrossRef]

194. Smethurst, P.J.; Huth, N.I.; Masikati, P.; Sileshi, G.W.; Akinnifesi, F.K.; Wilson, J.; Sinclair, F. Accurate crop yield predictions from modelling tree-crop interactions in gliricidia-maize agroforestry. Agric. Syst. 2017, 155, 70-77. [CrossRef]

195. Masikati, P.; Homann Kee-Tui, S.; Descheemaeker, K.; Sisito, G.; Senda, T.; Crespo, O.; Nhamo, N. Integrated Assessment of Crop-Livestock Production Systems Beyond Biophysical Methods: Role of Systems Simulation Models. In Smart Technologies for Sustainable Smallholder Agriculture: Upscaling in Developing Countries; Academic Press: Cambridge, MA, USA, 2017; pp. 257-278, ISBN 9780128105221.

196. van Wijk, M.T.; Rufino, M.C.; Enahoro, D.; Parsons, D.; Silvestri, S.; Valdivia, R.O.; Herrero, M. Farm household models to analyse food security in a changing climate: A review. Glob. Food Secur. 2014, 3, 77-84. [CrossRef]

197. Herrero, M.; Thornton, P.K.; Bernués, A.; Baltenweck, I.; Vervoort, J.; van de Steeg, J.; Makokha, S.; van Wijk, M.T.; Karanja, S.; Rufino, M.C.; et al. Exploring future changes in smallholder farming systems by linking socio-economic scenarios with regional and household models. Glob. Environ. Chang. 2014, 24, 165-182. [CrossRef]

198. Marcos, J.; Cornet, D.; Bussière, F.; Sierra, J. Water yam (Dioscorea alata L.) growth and yield as affected by the planting date: Experiment and modelling. Eur. J. Agron. 2011, 34, 247-256. [CrossRef]

199. Cornet, D.; Sierra, J.; Tournebize, R. Assessing Allometric Models to Predict Vegetative Growth of Yams in Different Environments. Agron. J. 2015, 107, 241-248. [CrossRef]

200. Cornet, D.; Sierra, J.; Tournebize, R.; Gabrielle, B.; Lewis, F.I. Bayesian network modeling of early growth stages explains yam interplant yield variability and allows for agronomic improvements in West Africa. Eur. J. Agron. 2016, 75, 80-88. [CrossRef]

201. Sommer, R.; Glazirina, M.; Yuldashev, T.; Otarov, A.; Ibraeva, M.; Martynova, L.; Bekenov, M.; Kholov, B.; Ibragimov, N.; Kobilov, R.; et al. Impact of climate change on wheat productivity in Central Asia. Agric. Ecosyst. Environ. 2013, 178, 78-99. [CrossRef]

202. Bobojonov, I.; Aw-Hassan, A. Impacts of climate change on farm income security in Central Asia: An integrated modeling approach. Agric. Ecosyst. Environ. 2014, 188, 245-255. [CrossRef]

203. Dixit, P.N.; Telleria, R. Advancing the climate data driven crop-modeling studies in the dry areas of Northern Syria and Lebanon: An important first step for assessing impact of future climate. Sci. Total Environ. 2015, 511, 562-575. [CrossRef]

204. Frija, A.; Telleria, R. Country-Level Bio-Economic Modeling of Agricultural Technologies to Enhance Wheat-Based Systems Productivity in the Dry Areas. Sustain. Agric. Res. 2016, 5, 113. [CrossRef]

205. Ghanem, M.E.; Marrou, H.; Soltani, A.; Kumar, S.; Sinclair, T.R. Lentil variation in phenology and yield evaluated with a model. Agron. J. 2015, 107, 1967-1977. [CrossRef]

206. Ghanem, M.E.; Marrou, H.; Biradar, C.; Sinclair, T.R. Production potential of Lentil (Lens culinaris Medik.) in East Africa. Agric. Syst. 2015, 137, 24-38. [CrossRef]

207. Soni, M.L.; Yadava, N.D.; Jat, S.R.; Gulati, I.J.; Rathore, V.S.; Birbal; Kumawat, A.; Glazirina, M. Evaluation of crop syst model for simulating green area index, soil water and yield of Psyllium in hyper arid partially irrigated zone of Rajasfhan. Ann. Arid Zone 2016, 55, 129-138.

208. Dixit, P.N.; Telleria, R.; Al Khatib, A.N.; Allouzi, S.F. Decadal analysis of impact of future climate on wheat production in dry Mediterranean environment: A case of Jordan. Sci. Total Environ. 2018, 610-611, 219-233. [CrossRef] [PubMed]

209. Mohammadi, R.; Armion, M.; Zadhasan, E.; Ahmadi, M.M.; Amri, A. The use of ammi model for interpreting genotype $\times$ environment interaction in durum wheat. Exp. Agric. 2018, 54, 670-683. [CrossRef]

210. Boote, K.J.; Jones, J.W.; Pickering, N.B. Potential uses and limitations of crop models. Agron. J. 1996, 88, 704-716. [CrossRef]

211. Di Paola, A.; Valentini, R.; Santini, M. An overview of available crop growth and yield models for studies and assessments in agriculture. J. Sci. Food Agric. 2016, 96, 709-714. [CrossRef] [PubMed]

212. Jones, J.W.; Antle, J.M.; Basso, B.; Boote, K.J.; Conant, R.T.; Foster, I.; Godfray, H.C.J.; Herrero, M.; Howitt, R.E.; Janssen, S.; et al. Toward a new generation of agricultural system data, models, and knowledge products: State of agricultural systems science. Agric. Syst. 2017, 155, 269-288. [CrossRef] [PubMed] 
213. Jame, Y.W.; Cutforth, H.W. Crop growth models for decision support systems. Can. J. Plant Sci. 1996, 76, 9-19. [CrossRef]

214. Lobell, D.B.; Cassman, K.G.; Field, C.B. Crop Yield Gaps: Their Importance, Magnitudes, and Causes. Annu. Rev. Environ. Resour. 2009, 34, 179-204. [CrossRef]

215. Kirkegaard, J.A.; Hunt, J.R.; McBeath, T.M.; Lilley, J.M.; Moore, A.; Verburg, K.; Robertson, M.; Oliver, Y.; Ward, P.R.; Milroy, S.; et al. Improving water productivity in the Australian grains industry-A nationally coordinated approach. Crop Pasture Sci. 2014, 65, 583-601. [CrossRef]

216. Cossani, C.M.; Reynolds, M.P. Physiological traits for improving heat tolerance in wheat. Plant Physiol. 2012, 160, 1710-1718. [CrossRef] [PubMed]

217. Zheng, B.; Chenu, K.; Chapman, S.C. Velocity of temperature and flowering time in wheat-Assisting breeders to keep pace with climate change. Glob. Chang. Biol. 2016, 22, 921-933. [CrossRef] [PubMed]

218. Yin, X.; Struik, P.C. Crop Systems Biology: Narrowing the Gaps between Crop Modelling and Genetics; Yin, X., Struik, P.C., Eds.; Springer International Publishing: Cham, Switzerland, 2016; ISBN 9783319205625.

219. Chamberlin, J.; Pender, J.L.; Yu, B. Development Domains for Ethiopia: Capturing the Geographical Context of Smallholder Development Options; IFPRI-DSGD Discussion Paper No. 49; IFPRI: Washington, DC, USA, 2006; $104 p$.

220. Kruseman, G.; Ruben, R.; Tesfay, G. Diversity and development domains in the Ethiopian highlands. Agric. Syst. 2006, 88, 75-91. [CrossRef]

221. Pender, J.; Place, F.; Ehui, S. Strategies for Sustainable Land Management in the East African Highlands; International Food Policy Research Institute: Washington, DC, USA, 2006; ISBN 0896297578.

222. Dias, M.P.N.M.; Navaratne, C.M.; Weerasinghe, K.D.N.; Hettiarachchi, R.H.A.N. Application of DSSAT Crop Simulation Model to Identify the Changes of Rice Growth and Yield in Nilwala River Basin for Mid-centuries under Changing Climatic Conditions. Procedia Food Sci. 2016, 6, 159-163. [CrossRef]

223. Jones, J.W.; Hoogenboom, G.; Porter, C.H.; Boote, K.J.; Batchelor, W.D.; Hunt, L.A.; Wilkens, P.W.; Singh, U.; Gijsman, A.J.; Ritchie, J.T. The DSSAT cropping system model. In European Journal of Agronomy; Elsevier: Amsterdam, The Netherlands, 2003; Volume 18, pp. 235-265.

224. Harris, I.; Jones, P.D.; Osborn, T.J.; Lister, D.H. Updated high-resolution grids of monthly climatic observations-The CRU TS3.10 Dataset. Int. J. Climatol. 2014, 34, 623-642. [CrossRef]

225. Hijmans, R.J.; Cameron, S.E.; Parra, J.L.; Jones, P.G.; Jarvis, A. Very high resolution interpolated climate surfaces for global land areas. Int. J. Climatol. 2005, 25, 1965-1978. [CrossRef]

226. New, M.; Hulme, M.; Jones, P. Representing Twentieth-Century Space-Time Climate Variability. Part I: Development of a 1961-90 Mean Monthly Terrestrial Climatology. J. Clim. 1999, 12, 829-856. [CrossRef]

227. New, M.; Lister, D.; Hulme, M.; Makin, I. A high-resolution data set of surface climate over global land areas. Clim. Res. 2002, 21, 1-25. [CrossRef]

228. Zhao, G.; Siebert, S.; Enders, A.; Rezaei, E.E.; Yan, C.; Ewert, F. Demand for multi-scale weather data for regional crop modeling. Agric. For. Meteorol. 2015, 200, 156-171. [CrossRef]

229. Jones, P.G.; Thornton, P.K. MarkSim: Software to generate daily weather data for Latin America and Africa. Agron. J. 2000, 92, 445-453. [CrossRef]

230. Jones, P.G.; Thornton, P.K. Generating downscaled weather data from a suite of climate models for agricultural modelling applications. Agric. Syst. 2013, 114, 1-5. [CrossRef]

231. Soltani, A.; Hoogenboom, G. A statistical comparison of the stochastic weather generators WGEN and SIMMETEO. Clim. Res. 2003, 24, 215-230. [CrossRef]

232. Soltani, A.; Hoogenboom, G. Assessing crop management options with crop simulation models based on generated weather data. Field Crops Res. 2007, 103, 198-207. [CrossRef]

233. Eden, J.M.; Widmann, M. Downscaling of GCM-simulated precipitation using model output statistics. J. Clim. 2014, 27, 312-324. [CrossRef]

234. Knutson, T.R.; Sirutis, J.J.; Vecchi, G.A.; Garner, S.; Zhao, M.; Kim, H.S.; Bender, M.; Tuleya, R.E.; Held, I.M.; Villarini, G. Dynamical downscaling projections of twenty-first-century atlantic hurricane activity: CMIP3 and CMIP5 model-based scenarios. J. Clim. 2013, 26, 6591-6617. [CrossRef]

235. Mitchell, T.D.; Carter, T.R.; Jones, P.D.; Hulme, M.; New, M. A Comprehensive Set of High-Resolution Grids of Monthly Climate for Europe and the Globe: The Observed Record (1901-2000) and 16 Scenarios (2001-2100); Tyndall Centre: Norwich, UK, 2004. 
236. Ramirez Villegas, J.; Jarvis, A. Downscaling Global Circulation Model Outputs: The Delta Method Decision and Policy Analysis Working Paper No. 1; International Center for Tropical Agriculture (CIAT): Cali, Colombia, 2010.

237. Ramirez, J.; Jarvis, A. Disaggregation of Global Circulation Model Outputs Decision and Policy Analysis Working Paper No. 2; International Center for Tropical Agriculture (CIAT): Cali, Colombia, 2010.

238. Hengl, T.; Heuvelink, G.B.M.; Kempen, B.; Leenaars, J.G.B.; Walsh, M.G.; Shepherd, K.D.; Sila, A.; MacMillan, R.A.; Mendes de Jesus, J.; Tamene, L.; et al. Mapping Soil Properties of Africa at $250 \mathrm{~m}$ Resolution: Random Forests Significantly Improve Current Predictions. PLoS ONE 2015, 10, e0125814. [CrossRef] [PubMed]

239. Gijsman, A.J.; Thornton, P.K.; Hoogenboom, G. Using the WISE database to parameterize soil inputs for crop simulation models. Comput. Electron. Agric. 2007, 56, 85-100. [CrossRef]

240. Romero, C.C.; Hoogenboom, G.; Baigorria, G.A.; Koo, J.; Gijsman, A.J.; Wood, S. Reanalysis of a global soil database for crop and environmental modeling. Environ. Model. Softw. 2012, 35, 163-170. [CrossRef]

241. Shangguan, W.; Dai, Y.; Duan, Q.; Liu, B.; Yuan, H. A global soil data set for earth system modeling. J. Adv. Model. Earth Syst. 2014, 6, 249-263. [CrossRef]

242. Adler, R.F.; Huffman, G.J.; Bolvin, D.T.; Curtis, S.; Nelkin, E.J. Tropical Rainfall Distributions Determined Using TRMM Combined with Other Satellite and Rain Gauge Information. J. Appl. Meteorol. 2000, 39, 2007-2023. [CrossRef]

243. Liu, Z.; Ostrenga, D.; Vollmer, B.; Deshong, B.; MacRitchie, K.; Greene, M.; Kempler, S. Global precipitation measurement mission products and services at the nasa ges disc. Bull. Am. Meteorol. Soc. 2017, 98, 437-444. [CrossRef]

244. Rozante, J.R.; Moreira, D.S.; de Goncalves, L.G.G.; Vila, D.A. Combining TRMM and Surface Observations of Precipitation: Technique and Validation over South America. Weather Forecast. 2010, 25, 885-894. [CrossRef]

245. Ruane, A.C.; Goldberg, R.; Chryssanthacopoulos, J. Climate forcing datasets for agricultural modeling: Merged products for gap-filling and historical climate series estimation. Agric. For. Meteorol. 2015, 200, 233-248. [CrossRef]

246. Chandler, W.; Hoell, J.M.; Westberg, D.; Zhang, T.; Stackhouse, P.W., Jr. NASA prediction of worldwide energy resource high resolution meteorology data for sustainable building design. In Proceedings of the Solar 2013 Conference (American Solar Energy Society), Baltimore, MD, USA, 16-20 April 2013.

247. White, J.W.; Hoogenboom, G.; Wilkens, P.W.; Stackhouse, P.W.; Hoel, J.M. Evaluation of Satellite-Based, Modeled-Derived Daily Solar Radiation Data for the Continental United States. Agron. J. 2011, 103, 1242. [CrossRef]

248. Zhang, T.; Stackhouse, P.W.; Chandler, W.S.; Westberg, D.J. Application of a global-to-beam irradiance model to the NASA GEWEX SRB dataset: An extension of the NASA Surface meteorology and Solar Energy datasets. Sol. Energy 2014, 110, 117-131. [CrossRef]

249. Vågen, T.-G.; Winowiecki, L.A.; Tondoh, J.E.; Desta, L.T.; Gumbricht, T. Mapping of soil properties and land degradation risk in Africa using MODIS reflectance. Geoderma 2016, 263, 216-225. [CrossRef]

250. Reynolds, M.P.; Quilligan, E.; Aggarwal, P.K.; Bansal, K.C.; Cavalieri, A.J.; Chapman, S.C.; Chapotin, S.M.; Datta, S.K.; Duveiller, E.; Gill, K.S.; et al. An integrated approach to maintaining cereal productivity under climate change. Glob. Food Secur. 2016, 8, 9-18. [CrossRef]

251. Dalgliesh, N.; Foale, M. Soil Matters. Monitoring Soil Water and Nutrients in Dryland Farming; Agricultural Production Systems Research Unit/CSIRO: Toowomba, QLD, Australia, 1998; ISBN 0643063757.

252. Donatelli, M.; Magarey, R.D.; Bregaglio, S.; Willocquet, L.; Whish, J.P.M.; Savary, S. Modelling the impacts of pests and diseases on agricultural systems. Agric. Syst. 2017, 155, 213-224. [CrossRef] [PubMed]

253. Fiaboe, K.K.M.; Fonseca, R.L.; de Moraes, G.J.; Ogol, C.K.P.O.; Knapp, M. Identification of priority areas in South America for exploration of natural enemies for classical biological control of Tetranychus evansi (Acari: Tetranychidae) in Africa. Biol. Control 2006, 38, 373-379. [CrossRef]

254. Pueyo, S.; He, F.; Zillio, T. The maximum entropy formalism and the idiosyncratic theory of biodiversity. Ecol. Lett. 2007, 10, 1017-1028. [CrossRef]

255. Adjemian, J.C.Z.; Girvetz, E.H.; Beckett, L.; Foley, J.E. Analysis of Genetic Algorithm for Rule-Set Production (GARP) modeling approach for predicting distributions of fleas implicated as vectors of plague, Yersinia pestis, in California. J. Med. Entomol. 2006, 43, 93-103.

256. Parsa, S.; Kondo, T.; Winotai, A. The Cassava Mealybug (Phenacoccus manihoti) in Asia: First Records, Potential Distribution, and an Identification Key. PLoS ONE 2012, 7, e47675. [CrossRef] [PubMed] 
257. Magarey, R.D.; Fowler, G.A.; Borchert, D.M.; Sutton, T.B.; Colunga-Garcia, M.; Simpson, J.A. NAPPFAST: An Internet System for the Weather-Based Mapping of Plant Pathogens. Plant Dis. 2007, 91, 336-345. [CrossRef]

258. Tonnang, H.E.Z.; Sporleder, M.; Juarez, H.; Carhuapoma, P.; Krosc, J. Insect Life Cycle Modelling (ILCYM) software-A generic platform for developing insect phenology models, population analysis and risk mapping. In Potato and Sweetpotato in Africa: Transforming the Value Chains for Food and Nutrition Security; CABI: Wallingford, UK, 2015; pp. 350-361.

259. Sharpe, P.J.H.; DeMichele, D.W. Reaction kinetics of poikilotherm development. J. Theor. Biol. 1977, 64, 649-670. [CrossRef]

260. Wagner, T.; Wu, H.-I.; Sharpe, P.; Schoolfield, R.; Coulson, R. Modeling insect development rates: A literature review and application of a biophysical model. Ann. Entomol. Soc. Am. 1984, 77, 208-220. [CrossRef]

261. Fand, B.B.; Tonnang, H.E.Z.; Kumar, M.; Bal, S.K.; Singh, N.P.; Rao, D.V.K.N.; Kamble, A.L.; Nangare, D.D.; Minhas, P.S. Predicting the impact of climate change on regional and seasonal abundance of the mealybug Phenacoccus solenopsis Tinsley (Hemiptera: Pseudococcidae) using temperature-driven phenology model linked to GIS. Ecol. Model. 2014, 288, 62-78. [CrossRef]

262. Chivers, C.; Leung, B.; Yan, N.D. Validation and calibration of probabilistic predictions in ecology. Methods Ecol. Evol. 2014, 5, 1023-1032. [CrossRef]

263. Nedorezov, L.V.; Löhr, B.L.; Sadykova, D.L. Assessing the importance of self-regulating mechanisms in diamondback moth population dynamics: Application of discrete mathematical models. J. Theor. Biol. 2008, 254, 587-593. [CrossRef]

264. Humphreys, E.; Kukal, S.S.; Christen, E.W.; Hira, G.S.; Balwinder-Singh; Sudhir-Yadav; Sharma, R.K. Halting the groundwater decline in north-west india-which crop technologies will be winners? Adv. Agron. 2010, 109, 155-217. [CrossRef]

265. Balwinder-Singh; Humphreys, E.; Sudhir-Yadav; Gaydon, D.S. Options for increasing the productivity of the rice-wheat system of north-west India while reducing groundwater depletion. Part 1 . Rice variety duration, sowing date and inclusion of mungbean. Field Crops Res. 2015, 173, 68-80. [CrossRef]

266. Balwinder-Singh; Humphreys, E.; Gaydon, D.S.; Sudhir-Yadav. Options for increasing the productivity of the rice-wheat system of north west India while reducing groundwater depletion. Part 2. Is conservation agriculture the answer? Field Crops Res. 2015, 173, 81-94. [CrossRef]

267. Dourte, D.R.; Gelcer, E.; Uryasev, O.; Staub, C.G.; Barreto, D.D.; Fraisse, C.W. Gridded, monthly rainfall and temperature climatology for El Niño Southern Oscillation impacts in the United States. Int. J. Climatol. 2017, 37, 2200-2208. [CrossRef]

268. Hunt, J.; Van Rees, H.; Hochman, Z.; Carberry, P.; Holzworth, D.; Dalgliesh, N.; Poulton, P.; Van Rees, S.; Huth, N.; Peake, A. Yield Prophet ${ }^{\circledR}$ : An online crop simulation service. In Proceedings of the 13th ASA Conference Ground Breaking Stuff, Perth, Australia, 10-14 September 2006; pp. 1-5.

269. Yield Prophet Lite. Available online: http:/ /www.yieldprophet.com.au/yplite/ (accessed on 11 April 2018).

270. Program for Advanced Numerical Irrigation (PANI). Mobile Application for Irrigation Schedule; Bangladesh Institute of ICT in Development: Dhaka, Bangladesh, 2016.

271. Krupnik, T.J.; Schulthess, U.; Ahmed, Z.U.; McDonald, A.J. Sustainable crop intensification through surface water irrigation in Bangladesh? A geospatial assessment of landscape-scale production potential. Land Use Policy 2017, 60, 206-222. [CrossRef] [PubMed]

272. Shamsudduha, M.; Chandler, R.E.; Taylor, R.G.; Ahmed, K.M. Recent trends in groundwater levels in a highly seasonal hydrological system: the Ganges-Brahmaputra-Meghna Delta. Hydrol. Earth Syst. Sci. 2009, 13, 2373-2385. [CrossRef]

273. Talsma, T. The Control of Saline Groundwater; Veenma: Wageningen, The Netherlands, 1963; Volume 63.

274. Wu, Q.; Christen, E.; Enever, D. BASINMAN: A Water Balance Model for Farms with Subsurface Pipe Drainage and On-Farm Evaporation Basin; Technical Report; CSIRO Land and Water: Griffith, Australia, 1998.

275. Ritchie, J.R.; Otter, S. Description and Performance of CERES-Wheat: A User-Oriented Wheat Yield Model; ARS United States Department of Agriculture, Agricultural Research Service: Beltsville, MD, USA, 1985; pp. 159-175.

276. Clevers, J.G.P.W. Application of a weighted infrared-red vegetation index for estimating leaf Area Index by Correcting for Soil Moisture. Remote Sens. Environ. 1989, 29, 25-37. [CrossRef] 
277. Maas, S.J.; Rajan, N. Estimating ground cover of field crops using medium-resolution multispectral satellite imagery. Agron. J. 2008, 100, 320-327. [CrossRef]

278. van Ittersum, M.K.; Cassman, K.G.; Grassini, P.; Wolf, J.; Tittonell, P.; Hochman, Z. Yield gap analysis with local to global relevance-A review. Field Crops Res. 2013, 143, 4-17. [CrossRef]

279. Schulthess, U.; Timsina, J.; Herrera, J.M.; McDonald, A. Mapping field-scale yield gaps for maize: An example from Bangladesh. Field Crops Res. 2013, 143, 151-156. [CrossRef]

280. Tittonell, P.; Giller, K.E. When yield gaps are poverty traps: The paradigm of ecological intensification in African smallholder agriculture. Field Crops Res. 2013, 143, 76-90. [CrossRef]

281. Mueller, N.D.; Gerber, J.S.; Johnston, M.; Ray, D.K.; Ramankutty, N.; Foley, J.A. Closing yield gaps through nutrient and water management. Nature 2012, 490, 254-257. [CrossRef]

282. Kruseman, G. Farm household behaviour and agricultural resource degradation: Using econometric and simulation approaches for policy analysis. In Development Economics between Markets and Institutions Incentives for Growth, Food Security and Sustainable Use of the Environment; Bulte, E., Ruben, R., Eds.; Wageningen Academic Publ.: Wageningen, The Netherlands, 2007; pp. 151-166, ISBN 9789086860470.

283. Acs, S.; Berentsen, P.B.M.; Huirne, R.B.M. Modelling conventional and organic farming: A literature review. NJAS Wagening. J. Life Sci. 2005, 53, 1-18. [CrossRef]

284. Brown, D. A Review of Bio-Economic Models; Cornell African Food Security and Natural Resource Management (CAFSNRM) Program, Cornell University: Ithaca, NY, USA, 2000; 101p.

285. Heckelei, T.; Britz, W.; Zhang, Y. Positive Mathematical Programming Approaches-Recent Developments in Literature and Applied Modelling. Bio-Based Appl. Econ. 2012, 1, 109-124. [CrossRef]

286. Janssen, S.; van Ittersum, M.K. Assessing farm innovations and responses to policies: A review of bio-economic farm models. Agric. Syst. 2007, 94, 622-636. [CrossRef]

287. Oriande, C.; Dillon, C.R. Developments in biophysical and bioeconomic simuation of agricultural systems: A review. Agric. Econ. 1997, 17, 45-58. [CrossRef]

288. Ruben, R.; Moll, H.; Kuyvenhoven, A. Integrating agricultural research and policy analysis: Analytical framework and policy applications for bio-economic modelling. Agric. Syst. 1998, 58, 331-349. [CrossRef]

289. van Wijk, M.T. From global economic modelling to household level analyses of food security and sustainability: How big is the gap and can we bridge it? Food Policy 2014, 49, 378-388. [CrossRef]

290. Zander, P.; Groot, J.C.J.; Josien, E.; Karpinski, I.; Knierim, A.; Meyer, B.C.; Madureira, L.; Rambonilaza, M.; Rossing, W.A.H. Farm models and economic valuation in the context of multifunctionality: A review of approaches from France, Germany, The Netherlands and Portugal. Int. J. Agric. Resour. Gov. Ecol. 2008, 7, 339. [CrossRef]

291. Capalbo, S.M.; Antle, J.M.; Seavert, C. Next generation data systems and knowledge products to support agricultural producers and science-based policy decision making. Agric. Syst. 2017, 155, 191-199. [CrossRef]

292. Groot, J.C.J.; Oomen, G.J.M.; Rossing, W.A.H. Multi-objective optimization and design of farming systems. Agric. Syst. 2012, 110, 63-77. [CrossRef]

293. Kanter, D.R.; Musumba, M.; Wood, S.L.R.; Palm, C.; Antle, J.; Balvanera, P.; Dale, V.H.; Havlik, P.; Kline, K.L.; Scholes, R.J.; et al. Evaluating agricultural trade-offs in the age of sustainable development. Agric. Syst. 2016, 163, 73-88. [CrossRef]

294. Kruseman, G. Bio-Economic Household Modelling for Agricultural Intensification. Ph.D. Thesis, Mansholt Studies, Mansholt Graduate School, Wageningen, The Netherlands, 2000.

295. Komarek, A.M.; Drogue, S.; Chenoune, R.; Hawkins, J.; Msangi, S.; Belhouchette, H.; Flichman, G. Agricultural household effects of fertilizer price changes for smallholder farmers in central Malawi. Agric. Syst. 2017, 154, 168-178. [CrossRef]

296. Komarek, A.M.; Waldron, S.A.; Brown, C.G. An exploration of livestock-development policies in western china. Food Policy 2012, 37, 12-20. [CrossRef]

297. Louhichi, K.; Kanellopoulos, A.; Janssen, S.; Flichman, G.; Blanco, M.; Hengsdijk, H.; Heckelei, T.; Berentsen, P.; Lansink, A.O.; Van Ittersum, M. FSSIM, a bio-economic farm model for simulating the response of EU farming systems to agricultural and environmental policies. Agric. Syst. 2010, 103, 585-597. [CrossRef]

298. van Dijk, M.; Morley, T.; Jongeneel, R.; van Ittersum, M.; Reidsma, P.; Ruben, R. Disentangling agronomic and economic yield gaps: An integrated framework and application. Agric. Syst. 2017, 154, 90-99. [CrossRef] 
299. van Dijk, M.; Meijerink, G.W. A review of global food security scenario and assessment studies: Results, gaps and research priorities. Glob. Food Secur. 2014, 3, 227-238. [CrossRef]

300. van Dijk, M.; Meijerink, G.W.; Rau, M.L.; Shutes, K. Mapping Maize Yield Gaps in Africa: Can a Leopard Change Its Spots? LEI Wageningen UR: The Hague, The Netherlands, 2012.

301. Garbulsky, M.F.; Peñuelas, J.; Gamon, J.; Inoue, Y.; Filella, I. The photochemical reflectance index (PRI) and the remote sensing of leaf, canopy and ecosystem radiation use efficiencies. A review and meta-analysis. Remote Sens. Environ. 2011, 115, 281-297. [CrossRef]

302. Zarco-Tejada, P.J.; Berni, J.A.J.; Suárez, L.; Sepulcre-Cantó, G.; Morales, F.; Miller, J.R. Imaging chlorophyll fluorescence with an airborne narrow-band multispectral camera for vegetation stress detection. Remote Sens. Environ. 2009, 113, 1262-1275. [CrossRef]

303. Janssen, S.J.C.; Porter, C.H.; Moore, A.D.; Athanasiadis, I.N.; Foster, I.; Jones, J.W.; Antle, J.M. Towards a new generation of agricultural system data, models and knowledge products: Information and communication technology. Agric. Syst. 2017, 155, 200-212. [CrossRef] [PubMed]

304. Keating, B.A.; Carberry, P.S.; Hammer, G.L.; Probert, M.E.; Robertson, M.J.; Holzworth, D.; Huth, N.I.; Hargreaves, J.N.G.; Meinke, H.; Hochman, Z.; et al. An overview of APSIM, a model designed for farming systems simulation. Eur. J. Agron. 2003, 18, 267-288. [CrossRef]

305. Soltani, A.; Sinclair, T.R. (Eds.) Modeling Physiology of Crop Development, Growth and Yield; CABI: Wallingford, UK, 2012; ISBN 9781845939700.

306. Soltani, A.; Sinclair, T.R. A simple model for chickpea development, growth and yield. Field Crops Res. 2011, 124, 252-260. [CrossRef]

307. Marrou, H.; Sinclair, T.R.; Metral, R. Assessment of irrigation scenarios to improve performances of Lingot bean (Phaseolus vulgaris) in southwest France. Eur. J. Agron. 2014, 59, 22-28. [CrossRef]

308. Hammer, G.; Cooper, M.; Tardieu, F.; Welch, S.; Walsh, B.; van Eeuwijk, F.; Chapman, S.; Podlich, D. Models for navigating biological complexity in breeding improved crop plants. Trends Plant Sci. 2006, 11, 587-593. [CrossRef] [PubMed]

309. Soltani, A.; Sinclair, T.R. A comparison of four wheat models with respect to robustness and transparency: Simulation in a temperate, sub-humid environment. Field Crops Res. 2015, 175, 37-46. [CrossRef]

310. Chenu, K.; Chapman, S.C.; Tardieu, F.; McLean, G.; Welcker, C.; Hammer, G.L. Simulating the yield impacts of organ-level quantitative trait loci associated with drought response in maize: A "gene-to-phenotype" modeling approach. Genetics 2009, 183, 1507-1523. [CrossRef]

311. Chenu, K.; Chapman, S.C.; Hammer, G.L.; McLean, G.; Salah, H.B.H.; Tardieu, F. Short-term responses of leaf growth rate to water deficit scale up to whole-plant and crop levels: An integrated modelling approach in maize. Plant Cell Environ. 2008, 31, 378-391. [CrossRef] [PubMed]

312. Messina, C.D.; Podlich, D.; Dong, Z.; Samples, M.; Cooper, M. Yield-trait performance landscapes: From theory to application in breeding maize for drought tolerance. J. Exp. Bot. 2011, 62, 855-868. [CrossRef] [PubMed]

313. Chapman, S.C.; Cooper, M.; Hammer, G.L.; Butler, D.G. Genotype by environment interactions affecting grain sorghum. II. Frequencies of different seasonal patterns of drought stress are related to location effects on hybrid yields. Aust. J. Agric. Res. 2000, 51, 209. [CrossRef]

314. Vadez, V.; Kholova, J.; Zaman-Allah, M.; Belko, N. Water: The most important 'molecular' component of water stress tolerance research. Funct. Plant Biol. 2013, 40, 1310. [CrossRef]

315. Calus, M.P.L.; Veerkamp, R.F. Accuracy of multi-trait genomic selection using different methods. Genet. Sel. Evol. 2011, 43, 26. [CrossRef]

316. Jia, Y.; Jannink, J.L. Multiple-trait genomic selection methods increase genetic value prediction accuracy. Genetics 2012, 192, 1513-1522. [CrossRef]

317. Pszczola, M.; Veerkamp, R.F.; de Haas, Y.; Wall, E.; Strabel, T.; Calus, M.P.L. Effect of predictor traits on accuracy of genomic breeding values for feed intake based on a limited cow reference population. Animal 2013, 7, 1759-1768. [CrossRef]

318. Heslot, N.; Akdemir, D.; Sorrells, M.E.; Jannink, J.L. Integrating environmental covariates and crop modeling into the genomic selection framework to predict genotype by environment interactions. Theor. Appl. Genet. 2014, 127, 463-480. [CrossRef] [PubMed] 
319. Pinto, R.S.; Reynolds, M.P.; Mathews, K.L.; McIntyre, C.L.; Olivares-Villegas, J.-J.; Chapman, S.C. Heat and Drought Adaptive QTL in a Wheat Population Designed to Minimize Confounding Agronomic Effects. Theor. Appl. Genet. 2010, 121, 1001-1021. [CrossRef]

320. Griffiths, S.; Wingen, L.; Pietragalla, J.; Garcia, G.; Hasan, A.; Miralles, D.; Calderini, D.F.; Ankleshwaria, J.B.; Waite, M.L.; Simmonds, J.; et al. Genetic Dissection of Grain Size and Grain Number Trade-Offs in CIMMYT Wheat Germplasm. PLoS ONE 2015, 10, e0118847. [CrossRef]

321. Rebetzke, G.J.; Rattey, A.R.; Farquhar, G.D.; Richards, R.A.; Condon, A.T.G. Genomic regions for canopy temperature and their genetic association with stomatal conductance and grain yield in wheat. Funct. Plant Biol. 2013, 40, 14. [CrossRef]

322. Chenu, K.; Deihimfard, R.; Chapman, S.C. Large-scale Characterization of Drought Pattern: A Continent-wide Modelling Approach Applied to the Australian Wheatbelt-Spatial and Temporal Trends. New Phytol. 2013, 198, 801-820. [CrossRef] [PubMed]

323. Fisher, R.A.; Mackenzie, W.A. Studies in crop variation: II. The manurial response of different potato varieties. J. Agric. Sci. 1923, 13, 311-320. [CrossRef]

324. Yates, F.; Cochran, W.G. The analysis of groups of experiments. J. Agric. Sci. 1938, 28, 556-580. [CrossRef]

325. Cornelius, P.; Crossa, J.; Seyedsadr, M. Statistical Tests and Estimators of Multiplicative Models for Genotype-by-Environment Interaction. In Genotype-by-Environment Interaction; Gauch, H.G., Kan, M.S., Eds.; CRC Press: Boca Raton, FL, USA, 1996; pp. 199-234, ISBN 978-1-4200-4937-4.

326. Crossa, J.; Cornelius, P.L. Sites Regression and Shifted Multiplicative Model Clustering of Cultivar Trial Sites under Heterogeneity of Error Variances. Crop Sci. 1997, 37, 406-415. [CrossRef]

327. Gauch, H.G., Jr. Model Selection and Validation for Yield Trials with Interaction. Biometrics 1988, 44, 705-715. [CrossRef]

328. Gollob, H.F. A statistical model which combines features of factor analytic and analysis of variance techniques. Psychometrika 1968, 33, 73-115. [CrossRef]

329. Mandel, J. The partitioning of interaction in analysis of variance. J. Res. Natl. Bur. Stand. Ser. B 1969, 73, 309-328. [CrossRef]

330. Piepho, H.-P.P. Methods for Comparing the Yield Stability of Cropping Systems. J. Agron. Crop Sci. 1998, 180, 193-213. [CrossRef]

331. Smith, A.B.; Cullis, B.R.; Thompson, R. The analysis of crop cultivar breeding and evaluation trials: An overview of current mixed model approaches. J. Agric. Sci. 2005, 143, 449-462. [CrossRef]

332. Smith, A.B.; Cullis, B.R.; Thompson, R. Exploring Variety-Environment Data Using Random Effects AMMI Models with Adjustments for Spatial Field Trend: Part 1: Theory. In Quantitative Genetics, Genomics and Plant Breeding; Kang, M.S., Ed.; CABI: Canberra Australia, 2001; pp. 323-335, ISBN 0851996019.

333. Burgueño, J.; Crossa, J.; Cornelius, P.L.; Yang, R.C. Using factor analytic models for joining environments and genotypes without crossover genotype $\times$ environment interaction. Crop Sci. 2008, 48, 1291-1305. [CrossRef]

334. Crossa, J.; Yang, R.-C.; Cornelius, P.L. Studying crossover genotype $\times$ environment interaction using linear-bilinear models and mixed models. J. Agric. Biol. Environ. Stat. 2004, 9, 362-380. [CrossRef]

335. Crossa, J.; Burgueño, J.; Cornelius, P.L.; McLaren, G.; Trethowan, R.; Krishnamachari, A. Modeling genotype $\times$ environment interaction using additive genetic covariances of relatives for predicting breeding values of wheat genotypes. Crop Sci. 2006, 46, 1722-1733. [CrossRef]

336. Denis, J.B. Two way analysis using covariates. Statistics 1988, 19, 123-132. [CrossRef]

337. Van-Eeuwijk, F.A.; Denis, J.B. Kang Incorporating additional information on genotypes and environments in models for two-way genotype by environment tables. In Genotype-by-Environment Interaction: New Perspectives; Gauch, H.G., Kang, M., Eds.; CRC Press: Boca Raton, FL, USA, 1996; pp. 15-49, ISBN 978-1-4200-4937-4.

338. Vargas, M.; Crossa, J.; Van Eeuwijk, F.A.; Ramírez, M.E.; Sayre, K. Using partial least squares regression, factorial regression, and AMMI models for interpreting genotype x environment interaction. Crop Sci. 1999, 39, 955-967. [CrossRef]

339. Vargas, M.; Crossa, J.; Van Eeuwijk, F.; Sayre, K.D.; Reynolds, M.P. Statistics: Interpreting treatment $\times$ environment interaction in agronomy trials. Agron. J. 2001, 93, 949-960. [CrossRef]

340. Yin, X.; Van Oijen, M.; Schapendonk, A.H.C.M. Extension of a biochemical model for the generalized stoichiometry of electron transport limited C3 photosynthesis. Plant Cell Environ. 2004, 27, 1211-1222. [CrossRef] 
341. Hwang, C.; Correll, M.J.; Gezan, S.A.; Zhang, L.; Bhakta, M.S.; Vallejos, C.E.; Boote, K.J.; Clavijo-Michelangeli, J.A.; Jones, J.W. Next generation crop models: A modular approach to model early vegetative and reproductive development of the common bean (Phaseolus vulgaris L). Agric. Syst. 2017, 155, 225-239. [CrossRef] [PubMed]

342. Meuwissen, T.H.; Hayes, B.J.; Goddard, M.E. Prediction of total genetic value using genome-wide dense marker maps. Genetics 2001, 157, 1819-1829. [PubMed]

343. Burgueño, J.; de los Campos, G.; Weigel, K.; Crossa, J. Genomic prediction of breeding values when modeling genotype $\times$ environment interaction using pedigree and dense molecular markers. Crop Sci. 2012, 52, 707-719. [CrossRef]

344. Jarquín, D.; Crossa, J.; Lacaze, X.; Du Cheyron, P.; Daucourt, J.; Lorgeou, J.; Piraux, F.; Guerreiro, L.; Pérez, P.; Calus, M.; et al. A reaction norm model for genomic selection using high-dimensional genomic and environmental data. Theor. Appl. Genet. 2014, 127, 595-607. [CrossRef] [PubMed]

345. Lopez-Cruz, M.; Crossa, J.; Bonnett, D.; Dreisigacker, S.; Poland, J.; Jannink, J.-L.; Singh, R.P.; Autrique, E.; de los Campos, G. Increased Prediction Accuracy in Wheat Breeding Trials Using a Marker $\times$ Environment Interaction Genomic Selection Model. G3 Genes Genomes Genet. 2015, 5, 569-582. [CrossRef]

346. Asseng, S.; Ewert, F.; Martre, P.; Rötter, R.P.; Lobell, D.B.; Cammarano, D.; Kimball, B.A.; Ottman, M.J.; Wall, G.W.; White, J.W.; et al. Rising temperatures reduce global wheat production. Nat. Clim. Chang. 2015, 5, 143-147. [CrossRef]

347. Montesinos-López, O.A.; Montesinos-López, A.; Crossa, J.; Toledo, F.H.; Pérez-Hernández, O.; Eskridge, K.M.; Rutkoski, J. A Genomic Bayesian Multi-trait and Multi-environment Model. G3 2016, 6, 2725-2744. [CrossRef]

348. Sida, T.S.; Baudron, F.; Kim, H.; Giller, K.E. Climate-smart agroforestry: Faidherbia albida trees buffer wheat against climatic extremes in the Central Rift Valley of Ethiopia. Agric. For. Meteorol. 2018, 248, 339-347. [CrossRef]

349. Kruseman, G.; Bade, J. Agrarian policies for sustainable land use: Bio-economic modelling to assess the effectiveness of policy instruments. Agric. Syst. 1998, 58, 465-481. [CrossRef]

350. Louhichi, K.; Gomez y Paloma, S. A farm household model for agri-food policy analysis in developing countries: Application to smallholder farmers in Sierra Leone. Food Policy 2014, 45, 1-13. [CrossRef]

351. Dukeman, A.; Adams, J.A.; Edmondson, J. Extensible collaborative autonomy using GAMS. In Proceedings of the 31st Annual ACM Symposium on Applied Computing-SAC'16, Pisa, Italy, 4-6 April 2016; ACM Press: New York, NY, USA, 2016; pp. 281-283.

352. Wossen, T.; Berger, T. Climate variability, food security and poverty: Agent-based assessment of policy options for farm households in Northern Ghana. Environ. Sci. Policy 2015, 47, 95-107. [CrossRef]

353. Zimmermann, A.; Heckelei, T.; Domínguez, I.P. Modelling farm structural change for integrated ex-ante assessment: review of methods and determinants. Environ. Sci. Policy 2009, 12, 601-618. [CrossRef]

354. Antle, J.M.; Capalbo, S.M. Econometric-process models for integrated assessment of agricultural production systems. Am. J. Agric. Econ. 2001, 83, 389-401. [CrossRef]

355. van Wijk, M.T.; Tittonell, P.; Rufino, M.C.; Herrero, M.; Pacini, C.; de Ridder, N.; Giller, K.E. Identifying key entry-points for strategic management of smallholder farming systems in sub-Saharan Africa using the dynamic farm-scale simulation model NUANCES-FARMSIM. Agric. Syst. 2009, 102, 89-101. [CrossRef]

356. Rosegrant, M.W.; IMPACT Development Team. International Model for Policy Analysis of Agricultural Commodities and Trade (IMPACT): Model Description; International Food Policy Research Institute (IFPRI): Washington, DC, USA, 2012.

357. Pardey, P.G.; Beddow, J.M.; Hurley, T.M.; Beatty, T.K.M.; Eidman, V.R. A Bounds Analysis of World Food Futures: Global Agriculture Through to 2050. Aust. J. Agric. Resour. Econ. 2014, 58, 571-589. [CrossRef]

358. Woltjer, G.B.; Kuiper, M. The MAGNET Model: Module Description; LEI Wageningen UR: Wageningen, The Netherlands, 2014.

359. Smeets Kristkova, Z.; Van Dijk, M.; Van Meijl, H. Projections of long-term food security with R\&D driven technical change-A CGE analysis. NJAS Wagening. J. Life Sci. 2016, 77, 39-51. [CrossRef]

360. Lotze-Campen, H.; von Lampe, M.; Kyle, P.; Fujimori, S.; Havlik, P.; van Meijl, H.; Hasegawa, T.; Popp, A.; Schmitz, C.; Tabeau, A.; et al. Impacts of increased bioenergy demand on global food markets: An AgMIP economic model intercomparison. Agric. Econ. 2014, 45, 103-116. [CrossRef] 
361. Von Lampe, M.; Willenbockel, D.; Ahammad, H.; Blanc, E.; Cai, Y.; Calvin, K.; Fujimori, S.; Hasegawa, T.; Havlik, P.; Heyhoe, E.; et al. Why do global long-term scenarios for agriculture differ? An overview of the AgMIP global economic model intercomparison. Agric. Econ. 2014, 45, 3-20. [CrossRef]

362. Elliott, J.; Müller, C.; Deryng, D.; Chryssanthacopoulos, J.; Boote, K.J.; Büchner, M.; Foster, I.; Glotter, M.; Heinke, J.; Iizumi, T.; et al. The Global Gridded Crop Model Intercomparison: Data and modeling protocols for Phase 1 (v1.0). Geosci. Model Dev. 2015, 8, 261-277. [CrossRef]

363. Lunt, T.; Jones, A.W.; Mulhern, W.S.; Lezaks, D.P.M.; Jahn, M.M. Vulnerabilities to agricultural production shocks: An extreme, plausible scenario for assessment of risk for the insurance sector. Clim. Risk Manag. 2016, 13, 1-9. [CrossRef]

364. Pask, A.; Pietragalla, J.; Mullan, D. Physiological Breeding II: A Field Guide to Wheat Phenotyping; CIMMYT: Mexico City, Mexico, 2012; ISBN 9789706481825.

365. Chapman, S.; Merz, T.; Chan, A.; Jackway, P.; Hrabar, S.; Dreccer, M.; Holland, E.; Zheng, B.; Ling, T.; Jimenez-Berni, J. Pheno-Copter: A Low-Altitude, Autonomous Remote-Sensing Robotic Helicopter for High-Throughput Field-Based Phenotyping. Agronomy 2014, 4, 279-301. [CrossRef]

366. Tattaris, M.; Reynolds, M.P.; Chapman, S.C. A Direct Comparison of Remote Sensing Approaches for High-Throughput Phenotyping in Plant Breeding. Front. Plant Sci. 2016, 7, 1131. [CrossRef] [PubMed]

367. Gourdji, S.M.; Mathews, K.L.; Reynolds, M.; Crossa, J.; Lobell, D.B. An assessment of wheat yield sensitivity and breeding gains in hot environments. Proc. R. Soc. B 2013, 280, 20122190. [CrossRef] [PubMed]

368. Cramer, W.; Yohe, G.W.; Auffhammer, M.; Huggel, C.; Molau, U.; Dias, M.A.F.S.; Leemans, R. Climate Change 2014 Impacts, Adaptation, and Vulnerability; Field, C.B., Barros, V.R., Dokken, D.J., Mach, K.J., Mastrandrea, M.D., Eds.; Cambridge University Press: Cambridge, UK, 2014; ISBN 9781107415379.

369. Delacy, I.H.; Dieters, M.J.; Crossa, J.; Godwin, I.D.; Arief, V.; Batley, J.; Davenport, G.; Dreisigacker, S.; Duveiller, E.; Edwards, D.; et al. Towards a Wheat Phenome Atlas and a Phenome Atlas Toolbox: What are they? What Progress? In Proceedings of the 11th International Wheat Genetics Symposium, Brisbane, QLD, Australia, 24-29 August 2008; Appels, R., Eastwood, R., Lagudah, E., Langridge, P., Lynne, M.M., Eds.; Sydney University Press: Brisbane, QLD, Australia, 2008; pp. 394-397.

370. Sinclair, T.R.; Messina, C.D.; Beatty, A.; Samples, M. Assessment across the united states of the benefits of altered soybean drought traits. Agron. J. 2010, 102, 475-482. [CrossRef]

371. Tonnang, H.E.Z.; Nedorezov, L.V.; Owino, J.O.; Ochanda, H.; Löhr, B. Host-parasitoid population density prediction using artificial neural networks: diamondback moth and its natural enemies. Agric. For. Entomol. 2010, 12. [CrossRef]

372. Guimapi, R.Y.A.; Mohamed, S.A.; Okeyo, G.O.; Ndjomatchoua, F.T.; Ekesi, S.; Tonnang, H.E.Z. Modeling the risk of invasion and spread of Tuta absoluta in Africa. Ecol. Complex. 2016, 28, 77-93. [CrossRef]

373. Chapman, S.; Cooper, M.; Podlich, D.; Hammer, G. Evaluating Plant Breeding Strategies by Simulating Gene Action and Dryland Environment Effects. Agron. J. 2003, 95, 99-113. [CrossRef]

374. Letort, V.; Mahe, P.; Cournède, P.H.; De Reffye, P.; Courtois, B. Quantitative genetics and functional-structural plant growth models: Simulation of quantitative trait loci detection for model parameters and application to potential yield optimization. Ann. Bot. 2008, 101, 1243-1254. [CrossRef]

375. Quilot-Turion, B.; Génard, M.; Valsesia, P.; Memmah, M.-M. Optimization of Allelic Combinations Controlling Parameters of a Peach Quality Model. Front. Plant Sci. 2016, 7, 1873. [CrossRef]

(C) 2018 by the authors. Licensee MDPI, Basel, Switzerland. This article is an open access article distributed under the terms and conditions of the Creative Commons Attribution (CC BY) license (http://creativecommons.org/licenses/by/4.0/). 